Working Paper 2010:10

Department of Economics

\title{
Rational Expectations and the Puzzling No-Effect of the Minimum Wage
}

Sara Pinoli 
Department of Economics

Working paper 2010:10

Uppsala University

June 2010

P.O. Box 513

ISSN 1653-6975

SE-751 20 Uppsala

Sweden

Fax: +46184711478

Rational Expectations and the Puzzling No-Effect of the

Minimum Wage Gender, Wages

SARA PINOLI

Papers in the Working Paper Series are published on internet in PDF formats.

Download from http://www.nek.uu.se or from S-WoPEC http://swopec.hhs.se/uunewp/ 


\title{
Rational Expectations and the Puzzling No-Effect of the Minimum Wage*
}

\author{
Sara Pinoli ${ }^{\dagger}$
}

\begin{abstract}
This paper argues that expectations are an important element that need to be included into the analysis of the effects of the minimum wage on employment. We show in a standard matching model that the observed employment effect is higher the lower is the likelihood associated with the minimum wage variation. On the other side, there is a significant anticipation effect, ignored in the literature. This property is able to explain the controversial results found in the empirical studies. When the policy is anticipated, the effect at the time of the actual variation is small and potentially hard to identify. The model is tested on Spanish data, taking advantage of the unexpected change in the minimum wage following the election of Zapatero in 2004.
\end{abstract}

JEL Classification: D21, J23, J38

Keywords: Minimum wage, Expectations, Heterogeneous matches

${ }^{*}$ This research was started while I was visiting at CEMFI, where I received valuable guidance from Claudio Michelacci and Samuel Bentolila. This paper benefitted from useful comments and suggestions from Tito Boeri, Michele Pellizzari, Antonella Trigari, Giuseppe Bertola, Giovanni Pica, and Alessandro Sembenelli. Many thanks to seminar participants at Bocconi University and CEMFI and participants at AIEL Annual Conference, Collegio Carlo Alberto Workshop, RES, SIE and Brucchi Luchino Workshop. All remaining errors are mine. Financial support from Bocconi University and Fondazione Rodolfo De Benedetti is gratefully acknowledged.

${ }^{\dagger}$ Department of Economics, University of Uppsala. E-mail: sara.pinoli@nek.uu.se 


\section{Introduction}

Minimum wages were first introduced in Australia and New Zealand in the late 19th century and are now in force in more than $90 \%$ of all countries (ILO, 2006). Despite its widespread use, the minimum wage is still a debated issue. Its supporters assert that it helps prevent the excess of exploitation in the labor market and increases the living standards of the lowest paid up to some minimum acceptable standards. Detractors claim that the minimum wage may price low-skill workers out of market, harming rather than helping the poorest workers.

Economic theory does not provide a clear prediction about the employment effects of the minimum wage: in a competitive labor market a binding minimum wage reduces employment, but this is not necessarily the case in a monopsonistic labor market, where a higher wage may attract more workers without dampening the labor demand. The empirical literature is also controversial. On the one hand, older studies support the idea of a negative employment effect of the minimum wage. ${ }^{1}$ On the other hand, more recent contributions are characterized by a wide range of estimates.

This paper proposes a mechanism capable of reconciling those conflicting findings. The key ingredient is the introduction of expectations in the analysis of the minimum wage policy. In fact, minimum wage changes can often be foreseen. This is particularly true in countries such as France and Spain, where the statutory minimum wage is set to be updated every year, or in Italy and Germany, that have no minimum wage laws but rely on collective agreements between employer groups and trade unions, renegotiated at defined dates. In the light of these features, the minimum wage policy cannot be considered as an unpredictable shock; on the contrary rational agents form expectations about minimum wage movements and adjust their current behavior to the future economic environment. Hence, when the minimum wage actually changes the employment adjustment may be small because it has been partly anticipated.

We argue that the empirical literature has not been able to find conclusive results because the minimum wage variations under analysis were expected, so that the observed employment effect was relatively small and potentially hard to identify. Furthermore, the anticipation effect has been neglected, leading to an underestimate of the overall employment effect.

In this paper we develop a theoretical model that extend the Mortensen and Pissarides (1994) model. The labor market is characterized by search and matching frictions, heterogeneous stochastic matching, and endogenous separations. Expectations are taken into account: agents know that the minimum wage may increase in the future. In this framework, we compare expected and unexpected changes in the minimum wage. Their effects on employment differ in timing: the expected policy influences the labor market outcomes both before and after the actual variation, while the unexpected one has no anticipation effect.

The predictions of the model are then tested using Spanish data. Spain provides a suitable environment in order to test the role played by expectations. The Spanish statutory minimum wage is set to be updated yearly, and changes in this policy are usually predictable. But this is not always the case: the increase in the Spanish minimum wage following the election of José Luis Rodríguez Zapatero was largely unexpected. Zapatero became the new prime minister on 14th March 2004, three days after the terrorist attack to Atocha station. The attack favored Zapatero to the detriment of the former prime minister, José María Aznar.

\footnotetext{
${ }^{1}$ See Brown, Gilroy and Kohen (1982) for a review.
} 
The unexpected victory of the Socialist Party was soon followed by an equally unexpected increase in the minimum wage. Thus we estimate and compare the effect of the unexpected rise in the minimum wage after Zapatero election with the expected variations in other periods. Our analysis relies on individual data from the Economically Active Population Survey, 2000-2006. This longitudinal dataset is suitable to study not only the employment effect, but also the evolution of flows in and out of employment. The analysis of flows allows to identify the exact source for employment changing and to better appreciate the role of the minimum wage even when the net disemployment effect is negligible. ${ }^{2}$

In line with the literature, we identify the affected group with the youth, and a difference in difference approach is implemented using the adult as a control group. One possible concern is that not all the young workers are actually low-paid. ${ }^{3}$ We test several specifications with more restrictive treatment and control groups.

Our results show that the employment effect depends on the nature of the minimum wage variation: expected policies have a significant anticipation effect on employment stock and flows. The magnitude of the anticipation effect is not negligible, but comparable with the effects at the time of the policy and in the following period. Temporary workers turn out to be the most affected, while separations do not significantly increase for permanent workers.

The plan of the paper is as follows. Section 2 provides a review of the literature on the minimum wage. The role of expectations is discussed in Section 3. Section 4 presents the model, both with and without expectations, and compare the resulting disemployment effect of the minimum wage policy. The empirical analysis is detailed in Section 5 and Section 6. Section 7 concludes.

\section{The employment effect of the minimum wage}

The minimum wage policy is mainly a redistributive instrument; nevertheless economic literature focuses on its employment effects. ${ }^{4}$ The simple model of competitive labor market predicts that increasing the minimum wage above the competitive level leads to higher unemployment. Similar conclusions are drawn from a basic matching model, where equilibrium conditions require a rise in the minimum wage to be compensated by a lower market tightness, that means lower vacancy posting and lower job creation. However there is no clear evidence in support of the disemployment effect of the minimum wage.

The empirical literature can be divided in two waves: the first one ending in 1982, reviewed in Brown, Gilroy and Kohen (1982); and the second one, the "New Minimum Wage Research", starting in 1991 and summarized in Neumark and Wascher (2007). Different econometric strategies have been used to asses the impact of the minimum wage on youth employment. ${ }^{5}$ The First Wave of the Minimum Wage Research uses mainly time-series and aggregate data to estimate correlations between employment and the minimum wage. They

\footnotetext{
${ }^{2}$ The advantages of analyzing flows generated by the minimum wage policy have been first recognized in Portugal and Cardoso (2006).

${ }^{3}$ See Cahuc and Zylberberg (2004) for a brief discussion.

${ }^{4}$ Notably, some exceptions are Flinn (2006) and Boadway and Cuff (2001) who also analyze the effect of the minimum wage on welfare.

${ }^{5}$ Empirical studies typically limit their attention to young workers, because they are more likely to be employed at the minimum wage.
} 
generally find a negative effect of the minimum wage on youth employment, as summarized by Brown et al. (1982):

"time-series studies typically find that a 10 percent increase in the minimum wage reduces teenage employment by one to three percent" (p. 524).

But this approach has been widely criticized. The use of aggregate data may leave out many relevant variables giving rise to spurious correlation. ${ }^{6}$

The New Minimum Wage Research relies on case studies and panel data with controversial results. Long panel studies that incorporate both country and time variation in minimum wages tend, on the whole, to find negative and statistically significant employment effects of minimum wage increases, while zero or positive effects of the minimum wage on low-skill employment are supported by the majority of the U.S. studies using either short panel data or case studies on a state-specific change in the minimum wage. ${ }^{7}$

A well-known example of case study is the 1992 increase in New Jersey's minimum wage studied in a series of papers by Card and Krueger $(1994,2000)$. They implement a difference in difference approach comparing the evolution of fast-food employment in New Jersey with restaurant in eastern Pennsylvania as a control group. Their estimates show either no significant effect of the increase in the minimum wage on employment, either a positive effect. These results have been questioned by Neumark and Wascher (2000). They replicate the analysis of Card and Krueger (1994) replacing their survey based data with administrative payroll records, and find a negative effect on New Jersey's employment relative to Pennsylvania. But the debate is still open: Card and Krueger (2000) replied to Neumark and Wascher's criticism and confirmed their previous results even using payroll data.

Some studies in the New Minimum Wage Research exploit panel data to identify the employment effects of the minimum wage. For instance, Card (1992) studies the April 1990 increase in the federal minimum wage over different states, taking advantage of the variation in the distribution of wages. Low-wage regions should be more affected by the minimum wage change. Regressing the change in state teen employment on the fraction of affected workers (i.e. teenagers who earned between the old and the new minimum wage in 1989), and controls, Card does not find a significant effect of the 1990 minimum wage increase. On the other side, Neumark and Wascher support the disemployment effect of the minimum wage in a series of papers $(1992,2002,2007 \mathrm{~b})$. An important difference among these studies is the measure of the minimum wage: Card considers the fraction of workers at or near the minimum wage, while Neumark and Wascher make use of the Kaitz index. The Kaitz index is a coverage-weighted minimum wage relative to the average wage and it is the most common measure of the bite of the minimum wage. Nonetheless many concerns have been raised with regard to its computation and its suitability to account for the minimum wage

\footnotetext{
${ }^{6}$ The shortcomings of the time-series approach are discussed in detailed in Card and Krueger (1995). They claim that minimum wage effects on employment should ideally be examined using microdata sources and a natural-experiment methodology. Furthermore, they argue that only substantial changes in the minimum wage can be sensibly used to estimate the employment effect.

${ }^{7}$ In their review, Neumark and Wascher (2007) argue that the lack of significant employment losses found in some analysis could be due to the short time horizon cutting off part of the adjustment process.
} 
impact. Dolado et al. (1996) and Neumark and Wascher (2007) discuss the issue from several perspectives, but the suitability of the Kaitz index is still an open question.

In the end, the empirical literature has not yet been able to reach an agreement upon the effect of the minimum wage on employment, neither to establish the correct way to handle this issue.

How does economic theory explain the empirical controversial findings? Few cogent models have been proposed. One is the monopsony model, extensively studied and enriched by Alan Manning $(1995,2003,2004)$ in several papers. Firms are assumed to have some power in retaining workers and, therefore, some discretion over the wages they pay. If the minimum wage lies between the monopolistic wage and the competitive wage, a rise in its level may increase employment enhancing labor supply without dampening labor demand, but lowering firms' rent. Otherwise the minimum wage has a negative effect on employment. Monopsony can account for both positive and negative effects of the minimum wage, but the coherence of this framework has been questioned with regard to low wage labor markets. Those markets are characterized by a large number of relatively small employers and high worker mobility; hence they are closer to perfect competition then to monopsony.

A variant of the monopsony model is the efficiency wage model developed by Rebitzer and Taylor (1996). Employers have an incentive to limit employment in order to minimize the supervision cost, that is assumed to be increasing in firm's size. Higher minimum wage helps to solve the moral hazard problem: the cost of job loss to workers currently employed increases with the wage paid, so that the threat to dismiss shirking workers becomes more effective and lower resources need to be devoted to supervision and may be used to increase employment.

A matching model with endogenous search effort is also capable to produce different employment effect of the minimum wage. On one side, an increase in the minimum wage rises the value of working and may provide an incentive for unemployed to exert more effort in searching for a job. On the other side, the firm's rent diminishes and fewer vacancy are posted, so that the probability of getting a job decreases with opposite effect on the search effort. When the net impact on search effort is positive, the matching process becomes more efficient and may compensate for the reduction in job openings. ${ }^{8}$

In this paper we propose a different mechanism to account for a wide range of empirical results. Instead of focusing on the characteristics of the labor market, we look at the characteristic of the policy under analysis. A variation in the minimum wage may be expected or unexpected. Depending on this distinction, the employment effect will be different. In particular, we show that the disemployment effect following an expected change underestimates the overall effect.

The empirical literature has till now focused on the ex-post effect of expected variations in the minimum wage policy. Since this is only a component of the overall effect, it may be small and hard to identify. Marginal differences in the econometric strategy, in the dataset, or in the construction of the minimum wage index are then able to produce conflicting estimates. A clear example is the endless debate among Card and Krueger and Neumark and Wascher about the disemployment effect of the 1992 increase in New Jersey's minimum wage. The policy had been scheduled and announced in the early 1990, two years before the

\footnotetext{
${ }^{8}$ See Flinn (2006) for an empirical analysis of the effect of the minimum wage on search effort.
} 
actual change. The advance announcement allowed Card and Krueger to collect data pre and post the minimum wage variation, but it also allowed firms and workers to adjust their behavior. It is likely that most of the employment effect had already occurred by 1992 and the reaction to the actual increase in the minimum wage was small. ${ }^{9}$ In this case, estimates may be not robust to minor variations in the data or in the econometric strategy.

\section{The role of expectations}

The role of expectations in shaping the behavior of economic agents is well documented and has been extensively used to understand a variety of situations in which speculation about the future is a crucial factor in determining current action. The theory of rational expectations was first proposed by John F. Muth in the early sixties and, in 1995, Robert E. Jr. Lucas won a Nobel prize for his studies on expectations and monetary policy.

It is widely recognized that the effect of a policy depends on agents' expectations. The "policy ineffectiveness proposition" by Lucas (1972) states the neutrality of economic policies that have their effects solely by inducing forecast errors. But also policies that operate by affecting incentives have to take into account agents' expectations. For instance, the permanent income theory of consumption predicts that a tax-cut is bond to have only a marginal effect on consumption if agents expect it to be temporary.

Despite the acknowledged importance of expectations in economics, they have not been introduced in the analysis of the minimum wage policy. This is surprising, especially because variations in the minimum wage are often scheduled and announced in advance. Table 1 shows that in many countries the minimum wage is revised on a regular basis, typically once a year. ${ }^{10}$ The frequency of adjustment is fixed by law, when the minimum wage is statutory, or by collective contracts, if the minimum wage is negotiated. Also, the criteria guiding the minimum wage revision are often stated by law. This is the case in Belgium, Luxemburg, Netherlands, France, Portugal, Spain, Canada and other countries, where the minimum wage is updated according to inflation, or the level of average wages, productivity, or other indicators. ${ }^{11}$

In the light of these features, the minimum wage policy cannot be considered an unpredictable shock. Agents operating in the labor market have the possibility and the incentive to form expectations about the timing and the magnitude of future minimum wage changes, since the profitability of an employment relationship depends also on future wages. Expected variations in the minimum wage affect the current value of a job and, in turn, the job creation and job destruction decisions. Then, when the minimum wage actually increases, the employment adjustment will be small because it has been partly anticipated.

Note that in order for expectations to play a role we need to assume some form of rigidities in the market. In a perfectly competitive market, an increase in the minimum wage always

\footnotetext{
${ }^{9}$ It is not possible to test for the role of expectations on the New Jersey case study due to the lack of data preceding 1990.

${ }^{10}$ The updating process concerns the nominal minimum wage. The real minimum wage varies continuously due to inflation and these variations may be expected or not. Given that in the past two decades inflation has been relatively low and stable, we argue that the real minimum wage changes were predictable and expected. In the model, we abstract from changes caused only by inflation because they are marginal and not likely to significantly affect agents' behavior.

${ }^{11}$ Source: ILO database on the minimum wage policy.
} 
implies a fall in employment at the time of the policy - regardless of expectations - because labor demand and labor supply depends only on current prices and productivity. Instead, with matching frictions a firm's current optimization problem depends also on future values and expectations. At the time the policy becomes expected it is optimal to reduce job inflows, since those worker will cost more in the future. It is also optimal to decrease the employment stock and destroy jobs that were formerly productive, even though the current net value of the wage is still low and the current net value of the match - productivity minus wage - is positive. Some of the matches that are expected to become unproductive in the future are separated in advance because, due to frictions, it takes time to find a new worker and replace the former one.

\section{The model}

The model is built to mimic the labor market of low wage workers, i.e. the wage is fixed at the minimum wage level. The labor market is characterized by search and matching frictions, heterogeneous stochastic matches and endogenous separations.

Frictions are summarized by the matching function $m(v, u)$, with constant returns to scale. Unemployed workers, $u$, and firms with vacancies, $v$, meet with probability $p=\frac{m(v, u)}{u}$ and $q=\frac{m(v, u)}{v}$, respectively. Let's call $\theta$ the market tightness, i.e. the ratio between vacancies over unemployment. The higher is $\theta$, the higher is the probability to find a job for a worker, $p$, and the lower is the probability to meet a worker for a firm, $q$.

The productivity of a match is a stochastic draw, $x$, from a known probability distribution $H(x)$, at the time of the meeting. Observing $x$, the firm-worker pair decides whether or not to form the match and start production. Low realization of $x$ may be rejected because of the prospect of a better job match in the future. The minimum level of productivity such that the match is formed is called hiring standard, $a$.

Match productivity $x$ can be hit by a shock with frequency $\lambda$ and the new productivity level is drawn from $H(x)$, over the support $\left[x_{l}, x^{u}\right]$. Job separations occurs if the new productivity draw is lower than the productivity threshold $d$. A match may also be destroyed when the minimum wage increases and, at the new wage, the job is no more profitable. In case of separation, a firing tax $F$ is paid by the firm. ${ }^{12}$ Note that, due to the separation cost $F$, the productivity threshold $d$ is lower than the hiring standard $a$.

Firms know that the minimum wage may increase to $w_{2}$, and assign probability $\phi$ to this event. ${ }^{13}$ Over time expectations are updated and $\phi$ changes accordingly. We distinguish three phases. Initially, state 0 , agents do not expect the minimum wage to rise, the wage is

\footnotetext{
${ }^{12}$ Employment protection legislation takes several forms in different countries: requirement to give a notice period to the worker before dismissal becomes effective; severance payments; possibility for the worker to contest the dismissal in front of a court; etc. Most of the literature considers only the cost incurred by the firm and paid outside of the match, which can be modeled as a tax. This is necessary in order for the employment protection legislation not to be overruled by an appropriate wage contract. In this model wages are exogenously fixed at the minimum wage level, therefore it is irrelevant whether the cost $F$ is transferred to the worker or paid to a third part.

${ }^{13}$ Uncertainty pertains the occurrence of the increase in the minimum wage, while the magnitude is known. Allowing for uncertainty in the magnitude would not affect the results, as long as agents are risk neutral and expectations are rational, i.e. contain no systematic errors. As a sketch of proof, note that the future
} 
at level $w_{1}$ and the expectation parameter is $\phi_{0}=0 .{ }^{14}$ In state 1 the subjective probability $\phi$ increases to $\phi_{1}>\phi_{0}$, the wage is still $w_{1}$ but it is expected to increase in the future with a positive probability $\phi_{1}$. In the real world, expectations may be revised due to political announcements of a future variation in the minimum wage, or due to changes in the economic situation or in the political support such that the likelihood of an increase in the minimum wage varies. When the minimum wage actually rises, state 2 , the expected event has taken place, the wage changes to $w_{2}>w_{1}$ and $\phi_{2}$ is set back to zero. ${ }^{15}$

\subsection{Value functions}

There is a continuum of identical households with total mass equal to one and a continuum of identical firms, each one holding one job. Each worker receives the minimum wage $w$. Given our assumptions, the value of a filled job in period $i$ reads: ${ }^{16}$

$$
\begin{array}{rlr}
r J_{i}(x)= & x-w_{1}+\lambda \int_{d}^{x^{u}}\left[J_{i}(s)-J_{i}(x)\right] d H(s)+\lambda H(d)\left[V_{i}-F-J_{i}(x)\right] \\
& +\phi_{i} \max \left\{V_{i}-F-J_{i}(x) ; J_{2}(x)-J_{i}(x)\right\} & i=0,1 \\
r J_{2}(x)= & x-w_{2}+\lambda \int_{d}^{x^{u}}\left[J_{2}(s)-J_{2}(x)\right] d H(s)+\lambda H(d)\left[V_{2}-F-J_{2}(x)\right]
\end{array}
$$

where $w_{2}>w_{1}, \phi_{0}=0, \phi_{1}>0$.

In each period, a job produces $x$ and costs $w$; when it is hit by a shock, with arrival rate $\lambda$, its productivity is drawn from $H(x)$ over the support $\left[x^{l}, x^{u}\right]$. If the new productivity is below the threshold $d$, the job is destroyed, the firm gets a new vacancy $V$ and pays $F$, otherwise the job is continued. In state 1 , firms know that, with probability $\phi_{1}$, the minimum wage will increase to $w_{2}$ and the value of a job will change to $J_{2}(x)$. The job is destroyed if its new value is lower then the firing cost. Note that $J_{i}(x)$ is decreasing in the wage $w$ and in the expectation parameter $\phi$.

The value of a vacancy is:

$$
r V_{i}=-k+q(\theta) \int_{a}^{x^{u}}\left[J_{i}(s)-V_{i}\right] d H(s) \quad i=0,1,2
$$

where $k$ is the cost of posting a vacancy. The match productivity is drawn from $H(x)$. Conditional on meeting a worker, with probability $q(\theta)$, the match is formed and production

expected wage do not change including uncertainty on the magnitude:

$$
\begin{aligned}
E\left[w_{t+1}\right] & =E\left[(1-\phi) w_{1}+\phi\left(w_{2}+\varepsilon\right)\right] \\
& =(1-\phi) w_{1}+\phi w_{2}
\end{aligned}
$$

where $\varepsilon$ is a random noise centered around zero.

${ }^{14}$ Alternatively, we could assume that the initial subjective probability $\phi_{0}$ is positive, then compare a policy that does not affect expectations, $\phi_{1}=\phi_{0}$, with a policy that does, $\phi_{1} \neq \phi_{0}$. The implications of the model do not qualitatively change as long as $\phi_{1}>\phi_{0}$. Setting $\phi_{0}=0$ can be regarded as a normalization. Furthermore, this allow us to qualify the former policy as unexpected and the latter one as expected.

${ }^{15}$ State 2 is absorbing, i.e. once the world gets there, it will stay there forever, or as long as a new event occurs. We are implicitly assuming that agents expect the minimum wage to increase only once and for all. Alternatively, we could set both $\phi_{0}$ and $\phi_{2}$ to a positive, albeit small, value. This would account for the regular update of the minimum wage policy, without affecting the subsequent analysis.

${ }^{16}$ All the value functions presented in this section are in continuous time and at the steady state. 
takes place if the observed productivity is high enough, i.e. $x$ is higher than the hiring standard $a$.

Note that, in this simple framework, we abstract from the behavior of workers. We assume that $w$ is larger than the workers' outside option, so that they are always willing to form a match and to continue it.

Firms post vacancies as long as their value is positive. Free entry ensures that, in equilibrium, the value of a vacant position is zero, i.e. $V_{i}=0$. When a worker and a firm meet, they observe the match specific productivity $x$ and decide whether or not to form the match. Given wage rigidity, it could happen that the match is profitable for the worker but not for the employer. Hence, the match is formed only if the firm's surplus, $J-V$, is positive. The hiring standard solves $J(a)=0$ and gives the lower bound for acceptable matches. Once the match is formed, the employment protection regulation becomes binding and the firm's outside option reduces from $V$ to $V-F$. Therefore a job is destroyed only when its value falls below $-F$. The continuation decision is taken comparing the current productivity of the match with the threshold $d$, where $d$ solve the condition $J(d)=-F$.

\subsection{Expected increase in the minimum wage}

We define an increase in the minimum wage as expected if it has been announced or if some exogenous events - for instance, the party in power changes from the right wing to the left wing - increase the likelihood of a change in the wage policy. ${ }^{17}$ Recall that there are three states of the world, characterized by different wages $w$ and expectation parameters $\phi$. Expectations introduce interdependency among states. In particular, employment decisions taken in state 1 depends also on the value of matches in state 2.

In the following, we derive the equilibrium conditions and analyze the steady states and the transitions among states.

\subsubsection{Equilibrium conditions}

The firm's problem is solved backward, starting from state 2. Substituting the value functions in state 2 , namely equations 2 and 3 , into the free entry condition, $V_{2}=0$, the match formation condition, $J_{2}\left(a_{2}\right)=0$, and the job destruction condition, $J_{2}\left(d_{2}\right)=-F$, we get the equilibrium conditions:

$$
\frac{1}{r+\lambda} \int_{a_{2}}^{x^{u}}\left(s-a_{2}\right) d H(s)=\frac{k}{q\left(\theta_{2}\right)}
$$

\footnotetext{
${ }^{17}$ Note that, even if the minimum wage variation has been announced, this does not necessarily imply certainty about the future change. The evolution of the economic situation or of the political support may induce the government (or the unions, if the minimum wage is negotiated) to revise the annouced wage change.

An example is the 1992 increase in the New Jersey's minimum wage up to $\$ 5.05$ per hour. The policy had been scheduled in 1990, but the worsening of the New Jersey's economy rose concerns about the potential adverse impact of a higher minimum wage. The state legislature voted in March 1992 to phase in the planned increase over two years, but the vote fell just short of the margin required to override a gubernatorial veto, and the Governor allowed the $\$ 5.05$ rate to go into effect on April 1. In the end, the minimum wage increase took effect as originally planned, but expectations about it were far from certainty.
} 


$$
\begin{aligned}
& a_{2}=w_{2}-\frac{\lambda}{r+\lambda} \int_{d_{2}}^{x^{u}}\left(s-d_{2}\right) d H(s)+\lambda F \\
& d_{2}=w_{2}-r F-\frac{\lambda}{r+\lambda} \int_{d_{2}}^{x^{u}}\left(s-d_{2}\right) d H(s)
\end{aligned}
$$

Let us call conditions 4, 5 and 6 job creation (JC), match formation (MF) and job destruction (JD), respectively. The solution to the system of three equations gives the hiring standard $a$, the job destruction threshold $d$, and market tightness $\theta$. It can be shown that $a$ and $d$ are increasing in $w$ : a higher labor cost makes firms more choosy about forming and continuing a match. In contrast, $\theta$ is decreasing $w$ : for any productivity level, the value of a filled job is lower, less vacancies are posted, and the labor market tightness $\theta$ diminishes.

In state 1 agents take into account the future variation in the value of the match, therefore $J_{1}(x)$ depends on the value of a filled position in state 2 . From equation 1 , we have:

$$
\begin{gathered}
r J_{1}(x)= \\
\begin{cases}x-w_{1}+\lambda \int_{d_{1}}^{x^{u}}\left[J_{1}(s)-J_{1}(x)\right] d H(s)-\left[\lambda H\left(d_{1}\right)+\phi_{1}\right]\left[F+J_{1}(x)\right] & \text { if } x<d_{2} \\
x-w_{1}+\lambda \int_{d_{1}}^{x^{u}}\left[J_{1}(s)-J_{1}(x)\right] d H(s)-\lambda H\left(d_{1}\right)\left[F+J_{1}(x)\right]+\phi_{1}\left[J_{2}(x)-J_{1}(x)\right] & \text { if } x \geq d_{2}\end{cases}
\end{gathered}
$$

Equation 7 is depicted in Figure 1 together with the value function of a job in state 2 . The job value in state 1 is a piecewise function that changes slope at $x=d_{2}$. The first segment pertains to the low productivity matches, $x<d_{2}$. Those jobs are not profitable after the minimum wage shock and will be destroyed in state 2 . The second segment represents the high productivity matches, $x>d_{2}$, that are continued after the policy shock.

Note that the value of a job in state 1 is always higher than the respective value in state 2 because, at least in the current period, firms pay a lower wage. Hence the productivity thresholds $a_{1}$ and $d_{1}$ are unambiguously smaller than $a_{2}$ and $d_{2}$. The exact location of $J_{1}(x)$ depends on the value of the parameters of the model, in particular $w_{1}, w_{2}$ and $F$. Figure 1 shows two possible cases: $J_{1}^{A}(x)$ and $J_{1}^{B}(x)$. In case A the increase in the minimum wage causes the destruction of newly formed jobs, $a_{1}^{A}<d_{2}$. In case $B$ the initial hiring standard fully anticipates the future rise in the reservation productivity; only existing matches hit by negative productivity shocks are at risk of separation, while new jobs are sufficiently productive to survive state $2, a_{1}^{B}>d_{2}$. It can be proved that $J_{1}(x)$ falls in case A if the following condition is satisfied:

$$
(r+\lambda+\phi) F<C
$$

where $C=w_{2}-w_{1}+\frac{\lambda}{r+\lambda+\phi} \int_{d_{1}}^{d_{2}}\left(s-d_{1}\right) d H(s)+\frac{\lambda}{r+\lambda}\left[\int_{d_{1}}^{x^{u}}\left(s-d_{1}\right) d H(s)-\int_{d_{2}}^{x^{u}}\left(s-d_{2}\right) d H(s)\right]$.

Intuitively, when the increase in the minimum wage is high with respect to the firing cost $F$ (case $A$ ), it is convenient to form some matches that will be destroyed after the policy shock, $a_{1}^{A}<d_{2}$, because the actual revenues - the lower wage paid to the worker plus the value of production undertaken in state 1 - is higher than the future cost of separation. Viceversa, when $F$ is high with respect to the minimum wage variation, it is optimal to form only highly productive matches that will survive the policy shock, $a_{1}^{B}>d_{2} \cdot{ }^{18}$ Regardless of

\footnotetext{
${ }^{18}$ See Appendix A for a formal proof.
} 
the exact position of $J_{1}(x)$, it is always true that the hiring standard $a$ and the destruction threshold $d$ are lower in state 1 than in state 2 , and market tightness $\theta$ is higher.

In state 0 , agents do not expect the minimum wage to rise, i.e. they assign probability $\phi_{0}=0$ to this event. The value functions in state 0 are equal to the value functions in state 2 , except for the wage, which is $w_{1}<w_{2}$. The solution of the equilibrium conditions gives the two productivity thresholds, $a_{0}$ and $d_{0}$. They are lower than the respective values in state 1 and state 2 , whereas $\theta_{0}$ is higher. ${ }^{19}$

Knowing $a, d, \theta$, we can compute the steady state unemployment rate: ${ }^{20}$

$$
u_{i}=\frac{\lambda H\left(d_{i}\right)}{\lambda H\left(d_{i}\right)+\theta_{i} q\left(\theta_{i}\right)\left[1-H\left(a_{i}\right)\right]} \quad i=0,1,2
$$

where $\lambda H\left(d_{i}\right)$ is the job destruction rate, defined as the ratio of total job destruction to employment, and $\theta_{i} q\left(\theta_{i}\right)\left[1-H\left(a_{i}\right)\right]$ is the job finding rate, i.e. the ratio of total job creation to unemployment. Unemployment is increasing in the job destruction threshold, $d$, and in the hiring standard, $a$, and it is decreasing in market tightness, $\theta$. It follows that the unemployment rate is higher in state 1 than in state 0 , and it peaks in state 2 .

\subsubsection{Job flows and unemployment dynamics}

We showed in the previous section that both expectations and the actual rise in the minimum wage have a negative effect on the job value of matches for any given productivity level. The comparison across steady states gives the following:

$$
\left.\begin{array}{l}
a_{0}<a_{1}<a_{2} \\
d_{0}<d_{1}<d_{2} \\
\theta_{0}>\theta_{1}>\theta_{2}
\end{array}\right\} u_{0}<u_{1}<u_{2}
$$

Moving from one state to the other the expected labor cost increases, hence a higher productivity is required to form - higher hiring standard $a$ - and to continue a match - higher job destruction threshold $d$ - and less vacancies are posted - higher market tightness $\theta$. As a result, steady state unemployment increases.

How does unemployment move from one steady state to the other? In general, the dynamics of unemployment is given by the difference between inflows, job destruction, and outflows, match formation:

$$
\dot{u}=\lambda H(d)(1-u)-\theta q(\theta)[1-H(a)] u
$$

In steady state the two flows compensate each other and unemployment stays constant. The change in expectations and the increase in the wage act as a shock to the value functions, so that the previous equilibrium parameters $-a, d, \theta$ - do not satisfy anymore the equilibrium conditions JC, MF and JD. To ensure that agents are optimizing also out of the steady state,

\footnotetext{
${ }^{19}$ The equilibrium conditions are formally derived in Appendix A.

${ }^{20}$ Equation 9 is obtained by setting to zero the change in unemployment:

$$
\dot{u}=\lambda H(d)(1-u)-\theta q(\theta)[1-H(a)] u
$$

where $\lambda H(d)(1-u)$ is the job destruction and $\theta q(\theta)[1-H(a)] u$ measures the mass of job created.
} 
the key parameters have to vary in accordance with the shock. This in turn unbalances inflows and outflows and unemployment moves out of the steady state.

Consider the transition from state 0 to state 1 . The initial values of open and filled positions are defined by equations 3 and 1 respectively, with $w=w_{1}$ and $\phi=0$. Jobs are destroyed at rate $\lambda H\left(d_{0}\right)$ - job destruction rate - and new matches are formed at rate $\theta_{0} q\left(\theta_{0}\right)\left[1-H\left(a_{0}\right)\right] u_{0} /\left(1-u_{0}\right)$ - job creation rate. Flows are in equilibrium and unemployment is constant at level $u_{0}$. When an announcement or a political or economic shock takes place, expectations move from $\phi_{0}=0$ to $\phi_{1}>0$ and the value functions change to:

$$
\begin{aligned}
r V= & -k+q(\theta) \int_{a}^{x^{u}}[J(s)-V] d H(s)+\dot{V} \\
r J(x)= & x-w_{1}+\lambda \int_{d}^{x^{u}}[J(s)-J(x)] d H(s)+\lambda H(d)[V-F-J(x)] \\
& +\phi_{1} \max \left\{V-F-J(x) ; J_{2}(x)-J(x)\right\}+\dot{J}
\end{aligned}
$$

where $\dot{V}$ and $\dot{J}$ are the expected variations in the valuation of $V$ and $J$ over time. Equilibrium conditions $(V=0, J(a)=0, J(d)=-F)$ applied to 12 and 13 yield the following system of equations:

$$
\begin{gathered}
\frac{1}{r+\lambda} \int_{a}^{x^{u}}(s-a) d H(s)=\frac{k}{q(\theta)} \\
a= \begin{cases}d+(r+\lambda+\phi) F & \text { if } J(d)>0 \\
d+(r+\lambda) F+\phi \frac{d_{2}-d}{r+\lambda+\phi} & \text { if } J(d)<0\end{cases} \\
d=w_{1}-\lambda\left[\frac{1}{r+\lambda+\phi} \int_{d}^{d_{2}}(s-d) d H(s)+\left[1-H\left(d_{2}\right)\right] \frac{d_{2}-d}{r+\lambda+\phi}\right] \\
-\frac{\lambda}{r+\lambda} \int_{d_{2}}^{x^{u}}\left(s-d_{2}\right) d H(s)-r F
\end{gathered}
$$

Equations (14) to (16) do not depend on the time derivatives $\dot{V}$ and $\dot{J}$ and are identical to the equilibrium conditions for state 1 derived in Appendix A. ${ }^{21}$ This means that the key parameters, $a, d$ and $\theta$, jump at the new steady state value as soon as the shock occurs and do not move any more. The only sticky variable is unemployment, $u$, that adjusts according to equation 11.

The dynamics of flows and unemployment are depicted in Figures 2 to 4 . On impact, the job destruction rate rises from $\lambda H\left(d_{0}\right)$ to $\left\{\lambda H\left(d_{1}\right)+\left[H\left(d_{1}\right)-H\left(d_{0}\right)\right]\right\}$. The jump is triggered by the increase in the job destruction threshold, $d$, and by the separations of all matches with productivity in the range $d_{0} \leq x \leq d_{1}$. Then job destruction drops to $\lambda H\left(d_{1}\right)$ till the next shock. The job creation rate decreases from $\theta_{0} q\left(\theta_{0}\right)\left[1-H\left(a_{0}\right)\right] u_{0} /\left(1-u_{0}\right)$ to $\theta_{1} q\left(\theta_{1}\right)\left[1-H\left(a_{1}\right)\right] u_{0} /\left(1-u_{0}\right)$, because of the higher $a$ and the lower $\theta$. Then, as long as unemployment increases, job creation rises until it matches the higher job destruction rate at the new steady state. ${ }^{22}$

\footnotetext{
${ }^{21}$ It is easily showed that the optimizing conditions force the time derivatives $\dot{V}$ and $\dot{J}$ to be equal to zero. See Pissarides (2000) for a discussion of the out of the steady state dynamics.

${ }^{22}$ The dynamics of the job finding rate - i.e. the ratio between the number of newly formed match and unemployment, $\theta q(\theta)[1-H(a)]$ - is depicted in Figure 4. The job finding rate does not depend on $u$, therefore it jumps down from $\theta_{0} q\left(\theta_{0}\right)\left[1-H\left(a_{0}\right)\right]$ to $\theta_{1} q\left(\theta_{1}\right)\left[1-H\left(a_{1}\right)\right]$ without any transition.
} 
On impact unemployment also jumps, following the rise in the job destruction flows, but does not reach the new steady state level in one step. As long as the job destruction rate is higher than the job creation rate, the unemployment level increases and it adjusts slowly to the new steady state level $u_{1} \cdot{ }^{23}$ This is a well known property of the matching model (see Pissarides (2000)): frictions imply that unemployment is a predetermined variable and follows a stable and backward looking process governed by the difference between the job creation and the job destruction flows.

Once the minimum wage actually increases a second transition path starts, from $u_{1}$ to $u_{2}$. The hiring standard and the job destruction thresholds jump to the new steady state values $a_{2}$ and $d_{2}$, and market tightness falls to $\theta_{2}$. Job flows follow the same transition path discussed before and unemployment gradually rises.

The disemployment effect of the minimum wage is distributed over time: a first rise occurs between the announcement and the actual change

$$
\Delta u_{e x-a n t e}=u_{1}-u_{0}
$$

a second increase takes place following the actual variation in the minimum wage

$$
\Delta u_{e x-p o s t}=u_{2}-u_{1}
$$

\subsection{Unexpected increase in the minimum wage}

A minimum wage variation is unexpected if agents never assign a positive probability to the event. When the minimum wage actually increases, the economy moves directly from state 0 to state 2 .

Value functions and equilibrium conditions have been discussed in the previous sections. In this case we do not observe state 1 - the state with positive expectations about a change in the minimum wage - but we can use the results derived for state 0 and state 2 . As in the model with expectations, when the minimum wage increases the job destruction threshold $d$ and the hiring standard $a$ increase, while market tightness $\theta$ decreases. Therefore steady state unemployment increases.

The unemployment dynamics are represented by the dotted line in Figure 2. There is only one transition, from state 0 to state 1 . After the increase in the minimum wage, the unemployment rises from $u_{0}$ to $u_{2}$. The transition path of job flows and unemployment has been detailed in the previous section.

Note that, when the increase in the minimum wage is unexpected, the disemployment effect takes place only after the actual variation.

$$
\Delta u=u_{2}-u_{0}
$$

\footnotetext{
${ }^{23}$ The lenght of transitions depends on the primitive parameters of the model, in particular it depends on the efficiency of the matching function. At the time the minimum wage actually increases, the transition may not have finished yet, so that the steady state 1 is never reached. In order to simplify the comparisons among states, we assume that the steady state 1 is reached before the minimum wage variation occurs. Conclusions would be qualitatively the same if we allowed for a more general case.
} 


\subsection{Comparison}

Both expected and unexpected variations in the minimum wage lead to a rise in the unemployment rate. The difference is in the dynamics.

When the rise in the minimum wage is expected, the disemployment effect is split between the ex-ante effect - before the actual change - and the ex-post effect - after the actual change. Instead, when the increase in the minimum wage is unexpected, the disemployment effect is concentrated ex-post.

This distinction is not irrelevant when it comes to the empirical estimate of the minimum wage impact. All the empirical studies have analyzed the ex-post effect only, therefore neglecting an important component of the overall disemployment effect: the anticipation effect. Firms anticipate the policy and adjust their behavior in advance so that the ex-post impact of the minimum wage is smaller. Unemployment increases less, from $u_{1}$ to $u_{2}$, and the jump in job destruction and in the job finding rate is lower:

$$
\begin{array}{rll}
\frac{J D}{1-u}: & \lambda H\left(d_{2}\right)-\lambda H\left(d_{1}\right)<\lambda H\left(d_{2}\right)-\lambda H\left(d_{0}\right) \\
\frac{J C}{u}: & \theta_{1} q\left(\theta_{1}\right)\left[1-H\left(a_{1}\right)\right]-\theta_{2} q\left(\theta_{2}\right)\left[1-H\left(a_{2}\right)\right]<\begin{array}{r}
\theta_{0} q\left(\theta_{0}\right)\left[1-H\left(a_{0}\right)\right] \\
-\theta_{2} q\left(\theta_{2}\right)\left[1-H\left(a_{2}\right)\right]
\end{array}
\end{array}
$$

It can be shown that the higher is the likelihood associated to the policy, $\phi_{1}$, the lower is the observed effect on unemployment, job destruction and job creation, ${ }^{24}$ hence the harder is to identify the effect in the data and to get robust estimates. Note that expectations do not neutralize the disemployment effect of the minimum wage, but reduce its ex-post magnitude. In order to obtain a null or even positive employment effect we would need to include labor participation or search effort decisions, but this goes beyond our purposes. ${ }^{25}$

${ }^{24}$ This result comes from the solution of the following derivatives:

$$
\begin{aligned}
\frac{\partial \Delta u_{\text {ex-post }}}{\partial \phi_{1}} & =-\frac{\partial u_{1}}{\partial \phi_{1}}<0 \\
\frac{\partial \frac{J D}{1-u}}{\partial \phi_{1}} & =-\lambda \frac{\partial H\left(d_{1}\right)}{\partial \phi_{1}}<0 \\
\frac{\partial \frac{J C}{u}}{\partial \phi_{1}} & =\frac{\partial \theta_{1} q\left(\theta_{1}\right)\left[1-H\left(a_{1}\right)\right]}{\partial \phi_{1}}<0
\end{aligned}
$$

\footnotetext{
${ }^{25}$ In this model we abstract from workers' decision about optimal search effort. When the minimum wage increases, the value of being employed increases and could induce workers to exert more effort in searching for a job with positive effect on employment. On the other hand, higher minimum wage means also lower vacancy posting that is detrimental to the search effort. The net effect is ambiguous and there is no consensus on the empirical evidence.

Neumark and Wascher (1995) found a positive and significant effect of the minimum wage on young workers' search effort and used this evidence to explain the weak disemployment effect found in some studies. On the other side, Flinn (2006) did not find significant support for the minimum wage to rise the contact rates.
} 


\section{$5 \quad$ Empirical analysis}

The model presented in Section 4 predicts that the employment effect of an increase in the minimum wage is split between ex-ante and ex-post effect in the case of an expected policy, while there is only ex-post effect in the case of an unexpected policy. Testing the model requires the discrimination among expected and unexpected minimum wage changes. In general it is not possible to observe individual expectations about policy changes, but the recent history of Spain provides a useful identification strategy.

\subsection{Institutional framework}

The Spanish law provides the minimum wage to be adjusted every half a year, taking into account the cost of living, the level of wages and incomes in the country, the evolution of productivity, and the economic situation. In practice the government sets the interoccupational minimum wage only once a year by Royal Decree, following a period of consultation with the most representative trade unions and employers' associations. The new amount becomes mandatory from the first day of each following January. The minimum wage legislation applies to workers from all occupations, trades and economic sectors. Subminimum wages are specified for trainees; subminima cannot be less than 70, 80 and $90 \%$ of the inter-profession minimum wage for the first, second and third year of validity of the contract. Until 1997 the government fixed two minimum wages: one for adult workers ( +18 years old) and another for workers aged between 16 and 18. The difference was eliminated in 1998.

This particular setting suggests that minimum wage changes can be foreseen. Furthermore, Spain enjoyed considerable political stability after the death of Franco and the birth of democracy. From 1977 to now, Spain had four prime ministers only: Adolfo Suárez (centre-right coalition), Felipe González (Spanish Socialist Workers' Party), José María Aznar (People's Party), and José Luis Rodríguez Zapatero (Socialist Party). Political stability may have facilitated the formation of clear expectations.

The prediction of minimum wage variations has been particularly simple during the second Aznar's mandate. José María Aznar López served as the President of the Government of Spain from 1996 to 2004. In 1997 the government promoted a process of dialogue with trade unions and employers' organizations for the preparation of labor market reforms. The concertation led to three agreements: Interprofessional Agreement on Collective Bargaining, Interprofessional Agreement on Employment Stability, and Interprofessional Agreement to Fill the Gaps in Collective Bargaining. ${ }^{26}$ With respect to the wage setting, unions accepted wage moderation in exchange for a limitation in the use of temporary contracts. In the following period the minimum wage rose by two per cent each year, according to the inflation target. Taking into account the real inflation, this meant a slight but persistent decrease in the real minimum wage. ${ }^{27}$

Instead the increase in the minimum wage in July 2004 was largely unexpected, in the timing and in the magnitude. On 14th March of 2004, three days after a terrorist attack,

\footnotetext{
${ }^{26}$ See Molina Romo $(2003,2004)$ for an analysis of the concertation process in Spain in the 90s.

${ }^{27}$ The lowering of the real minimum wage was not a new experience for Spain. Table 3 shows that also before the Aznar government, despite the high increase in the nominal minimum wage, the real one was most of the time decreasing or roughly stable, due to high inflation rates in the 80 s. The novelty was in the concertation process and therefore the broad agreement and widespread knowledge of this plan.
} 
the Spanish Socialist Party won the election and José Luis Rodríguez Zapatero became the new premier. An important point in the socialist agenda was the increase in the minimum wage up to 600 euros monthly - the minimum wage was set at 460.50 euros in the beginning of 2004 - by the end of the mandate. Soon after the election, Zapatero announced a rise in the minimum wage by $6.6 \%$, mandatory from the beginning of July.

The Economist called Zapatero "the unexpected prime minister", speculating that his success was related, at least partly, to the bombing in Madrid. On the 11th March of 2004 three trains exploded in Atocha Station. The explosions killed 191 people and 1,500 were wounded. It has been the largest peacetime attacks in Spanish history. Spain was involved in Iraq war as an U.S. ally and has been threatened reprisals by Bin Laden in the October of 2003. Nevertheless, the conservative government pointed in the direction of ETA - the Basque separatist group that seeks the independence of the Basque country - as the author of the attack. This claim was not taken back despite many hints in the direction of Al-Qaeda. By the afternoon of the 13th of March it was already quite clear that the attack was executed by an Islamic terrorist group. Blaming ETA against the facts turned out to be a serious mistake for the right wing. The government was accused of manipulating information about the real authorship of the attacks to avoid the consequences of public anger at a bombing motivated by its foreign policy. Zapatero himself repeatedly accused the Popular Party of lying about those who were responsible for the attacks and promised to withdraw Spanish troops from Iraq, in case he was elected.

Before the bombing opinion polls pointed in favor of the People's Party (PP), but in a few days the election result was reversed. In a recent paper Montalvo(2006) identifies the effect of the terrorist attacks on the election result, comparing the voting behavior of the presential voters with respect to the absentee voters, i.e. the citizens abroad. The first group voted on the 14th of March, knowing about the terrorist attacks. The latter group was allowed to start voting from the 2nd of March, so that they could have voted before the bombing. A difference in difference estimator is constructed using data on voting results of Congressional elections from 1993 to 2004. The estimate shows that the terrorist attack reduced the support for the PP by approximately 5 percentage point. Therefore, the election of the Socialist Party was an unexpected event. It follows that the July-2004 rise in the minimum wage was also unexpected, as opposed to the widely expected variation previously carried out by the conservatory party. ${ }^{28}$

To summarize, the Spanish case provides us with two types of minimum wage changes: expected and unexpected. Now we can test the prediction of the model concerning the role of expectations in shaping the disemployment effect.

\subsection{Data}

The data used in the empirical investigation come from the Economically Active Population Survey (EPA) 2000-2006. ${ }^{29}$ EPA is a rotating quarterly survey carried out by the Spanish National Statistical Institution. Its main goal is to reveal the characteristics of the population living in the Spanish national territory. The survey's rotation scheme implies that every

\footnotetext{
${ }^{28}$ Immidiately after, the election, the July-2004 rise in the minimum wage became expected. In the empirical model we allow for an anticipation effect of this policy.

${ }^{29}$ INE, Enquesta de Población Activa, Anonimizado de Flujos, 2000-2006.
} 
new rotation group stays in the survey for six consecutive quarters; hence we can follow the employment story of individuals for one year and a half.

The sample size consists of about 64,000 households with approximately 150,000 individuals aged sixteen or more. The questionnaire is submitted to a single household respondent who answers for all the persons living in the household. The household respondent may change between successive interviews. This allows low attrition rate but increases the measurement error, especially in retrospective questions. The questionnaire is composed of several sections asking about educational attainment and working status of each individual in the household. The reference period for most questions is the week before the interview. The first quarter of each year also includes retrospective questions about the working status of the individual one year earlier. There are no information about earnings.

Table 3 shows that labor market participation is relatively low in Spain: over the 20002006 period only around 50 per cent of the Spanish labor force was employed, and 7 per cent was unemployed. Yet, participation rate was increasing from 0.53 in 2000 to 0.64 in 2006, driven from the higher participation of the youth, whose employment rate augmented from 34.5 to 42.2 per cent. Unemployment followed a decreasing trend and flows into employment almost doubled over the period. On the other side employment stability lowered and separations increased. Note that the share of temporary workers is considerably high in Spain: almost 70 per cent of the youth and 30 per cent of the adults are employed under fixed-term contracts.

\subsection{Econometric specification}

Three sets of equations are estimated. First, we analyze the effect of the minimum wage variation on the probability of being employed. Then, following Portugal and Cardoso (2006), we concentrate on flows in and out of employment, and we relate them to the change in the minimum wage. The analysis of the dynamics of flows allows us to identify the exact source for employment changes and to better appreciate the role of the minimum wage even when the net disemployment effect is small.

Exploiting the structure of the survey we can match $5 / 6$ of the individuals in any two consecutive quarters and check whether they changed status or not. We only distinguish between employment and non-employment, pooling together unemployed workers and inactive individuals. The reason is that variations in employment gives a better measure of the effect of the minimum wage than changes in the unemployment stock. If the minimum wage reduces job opportunities, some individuals may give up looking for jobs, and hence not be counted as unemployed. ${ }^{30}$ Then the harm of the job opportunities is not accounted by the unemployment measure. On the other side, some people may exit inactivity and start looking for better paid jobs, increasing unemployment and overestimating the harm of the minimum wage. Furthermore, the statistics on unemployment rely on a number of arbitrary choices. According to the ILO definition, the unemployed comprise those persons who were (1) without work during the reference week, (2) currently available for work, (3) actively seeking work. Hence, the distinction between unemployment and inactivity relies on arguable criteria, such as the definition of active search and the four weeks job-search

\footnotetext{
${ }^{30}$ This is particularly true for young individuals. Enrolling in education is an alternative to unemployment for them, therefore blurring the line between unemployment and inactivity (Neumark and Wascher, 2004).
} 
period. ${ }^{31}$

Our dependent variables are the employment status and the flows out of and into employment: (i) $y_{i t}^{e}$ is equal to 1 if individual $i$ is employed in quarter $t, 0$ otherwise; (ii) $y_{i t}^{\text {out }}$ is equal to 1 if individual $i$ is employed in quarter $t$ and non-employed in quarter $t+1$, and it is set at 0 if he/she is employed both at $t$ and $t+1$; (iii) $y_{i t}^{i n}$ is equal to 1 if individual $i$ is non-employed in quarter $t$ and employed in quarter $t+1$, and it is set at 0 if he/she is non-employed both at $t$ and $t+1$. We use the same econometric framework, probit, to model the employed status and the flows:

$$
\begin{aligned}
\operatorname{Pr}\left(y_{i t}^{e}=1\right) & =\Phi\left(Q_{i t}^{\prime} \rho\right) \\
\operatorname{Pr}\left(y_{i t}^{\text {out }}=1\right) & =\Phi\left(Z_{i t}^{\prime} \gamma\right) \\
\operatorname{Pr}\left(y_{i t}^{\text {in }}=1\right) & =\Phi\left(W_{i t}^{\prime} \delta\right)
\end{aligned}
$$

where $\Phi(\cdot)$ is the cumulative distribution of a standard normal, $Q_{i t}, Z_{i t}$ and $W_{i t}$ are the matrices of covariates (minimum wage variation, age, gender, education, time effect, etc.). Note that $\operatorname{Pr}\left(y_{i t}^{e}=1\right)$ is empirically equivalent to the employment probability; $\operatorname{Pr}\left(y_{i t}^{\text {out }}=1\right)$ and $\operatorname{Pr}\left(y_{i t}^{i n}=1\right)$ corresponds to the job destruction rate to employment, $\lambda H(d)$, and to the job finding rate, $\theta q(\theta)[1-H(a)]$, respectively.

The key variable is the variation - quarter to quarter - in the real minimum wage. The variable $U_{M W}$ identifies the unexpected increase in July 2004. All the other variations occurred to the real minimum wage are considered as expected, including those related to inflation, and are accounted by $E_{M W}$. In the regressions on flows the on impact effect of $U_{M W}$ and $E_{M W}$ is measured as the effect of the policy on the flow occurring between the quarter of the policy and the following quarter. Accordingly, in the employment regression the on impact effect of $U_{M W}$ and $E_{M W}$ is estimated at the quarter following the respective policy, as a result of the changes in flows. ${ }^{32}$

The minimum wage policy does not affect all workers, but only those who are low-earners, typically young, unexperienced workers. ${ }^{33}$ Accordingly, we identify the treatment group with the young, while the control group is composed by the adult. A proportional difference in difference approach is applied to estimate the following regression. For brevity we omit the subscript it.

$$
\operatorname{Pr}(y=1)=\Phi\left(\alpha_{0}+\alpha_{1} Y+\alpha_{2} Y * U_{M W}+\alpha_{3} Y * E_{M W}+T \eta+X \beta+\varepsilon\right)
$$

where $Y$ is a dummy equal to 1 when the individual is aged $16-24$ and 0 if older; ${ }^{34} T$ is a set of time dummies, one for each quarter; and $X$ is a set of covariates, including gender,

\footnotetext{
${ }^{31} \mathrm{~A}$ comprehensive report of the reasons underlying the choice of employment as a better measure of the minimum wage harm is given in Brown et al. (1982). See also Brandolini, Cipollone and Viviano (2006) for a discussion of the ILO unemployment definition.

${ }^{32}$ In practice, in the flow equations the variable $U_{M W}$ is positive in correspondence with the flow from 2004:Q3 to 2004:Q4 and zero otherwise. In the employment equation, $U_{M W}$ is positive in quarter 2004:Q4.

${ }^{33}$ Empirical studies show that the elasticity of employment to the minimum wage is negligible, except perhaps for youth employment. For example, the OECD (1998) cross-country study finds that a rise of $10 \%$ in the minimum wage entails a fall of between $2 \%$ and $4 \%$ in employment among those aged less than 20 . The impact is negative, but close to zero, also for individuals between 20 and 24 years old. On the other hand, the minimum wage has no effect on the employment of older workers.

${ }^{34}$ We consider only workers aged up to 54 years. Older workers are not included in order to minimize the contamination of results generated by early retirement decisions.
} 
education, and the region of residence. Due to the nonlinearity of the probit model, the treatment effect is not equal to the marginal effect of the interacted term, but it has to be computed as the incremental effect of the coefficient of the interaction term. ${ }^{35}$ In particular, the effect of the unexpected increase in the minimum wage on the treated group is computed as $\Phi\left(\alpha_{0}+\alpha_{1} Y+\alpha_{2} Y * U_{M W}+T_{2} \eta_{2}+X \beta+\varepsilon\right)-\Phi\left(\alpha_{0}+\alpha_{1} Y+T_{2} \eta_{2}+X \beta+\varepsilon\right)$; while $\Phi\left(\alpha_{0}+\alpha_{1} Y+\alpha_{3} Y * E_{M W}+T_{3} \eta_{3}+X \beta+\varepsilon\right)-\Phi\left(\alpha_{0}+\alpha_{1} Y+T_{3} \eta_{3}+X \beta+\varepsilon\right)$ measures the effect of an expected policy.

The model has implication for the timing of the treatment effect: an expected change in the minimum wage affects employment both before and after the actual variation, while an unexpected variation has effect only after the policy is implemented. The dynamics is introduced in equation 25 including pre and post effects:

$$
\operatorname{Pr}(y=1)=\Phi\left(\begin{array}{c}
\alpha_{0}+\alpha_{1} Y+\alpha_{2} Y * U_{M W}+\gamma_{1} Y * U_{M W-\text { pre }}+\gamma_{2} Y * U_{M W-\text { post }} \\
+\alpha_{3} Y * E_{M W}+\gamma_{3} Y * E_{M W-\text { pre }}+\gamma_{4} Y * E_{M W-\text { post }}+T \eta+X \beta+\varepsilon
\end{array}\right)
$$

where $Y * U_{M W-\text { pre }}$ and $Y * E_{M W-\text { pre }}$ accounts, respectively, for the impact of the unexpected and expected changes in the minimum wage in the period preceding the policy, and $Y *$ $U_{M W-p o s t}$ and $Y * E_{M W-p o s t}$ accounts for the impact in the following period.

The recent empirical literature (see Neumark and Wascher, 2007) stresses the importance of including lagged effects of the minimum wage arguing that it may take time to adjust to policy changes. In addition, we include the anticipation effect. ${ }^{36}$ An issue is the setting of the length of the dynamics. If a short length is chosen, it may miss part of the story, while if too long, it may capture events different from the policy under consideration. Therefore equation 26 is estimated using different lengths, from 0 to 2 quarters. ${ }^{37}$

The employment outflows regressions are replicated also focusing on temporary or permanent workers separately. The Spanish labor market is characterized by the coexistence of two types of employment contracts: fixed-term and open-ended contracts. The former are associated with low employment protection, whereas the latter are strongly protected by high separation costs and just-cause standard. An increase in the cost of labor is likely to affect the two groups of workers in a different way. Firms are likely to adjust the workforce dismissing temporary workers, instead of paying firing costs to terminate permanent contracts.

\subsection{Econometric issues}

The main concern in a difference in difference approach is the choice of proper treatment and control groups. Unfortunately EPA does not provide information about earnings, therefore we cannot precisely disentangle the low wage workers. Instead we exploit information from

\footnotetext{
${ }^{35} \mathrm{Ai}$ and Norton (2003) and Norton et al. (2004) are the first to stress that the marginal effect of the interacted term cannot be interpreted as the treatment effect in nonlinear models. The correct treatment effect is computed in Puhani (2008).

${ }^{36}$ Due to the frequency of the policies, it is not possible to estimate a set of separate dynamic effects at each pre and post period - i.e. 1, 2, 3, 4 quarters before the policy and 1, 2, 3, 4 quarters after - because those would systematically overlap giving rise to multicollinearity. For instance, $E_{M W-p r e 1}$ sistematically overlap

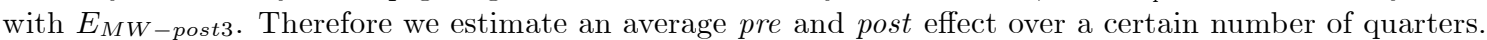

${ }^{37}$ Longer lengths have also been estimated, but they are only weakly identified due to the overlapping between pre and post effects.
} 
the Wage Structure Survey. Figure 5 reports the annual average earnings of Spanish workers in 2002 computed by age, gender, and educational attainments. Young workers receive significantly lower wages, 9,686.12 euros whereas the overall average is 19,802.45 euros. This supports the traditional comparison between young and adult individuals. On the other side, the 2002 annual minimum wage was set at 6,190.80 euros and among the young there are also high or medium wage earners who are not affected by the minimum wage change. Young workers always get lower wages than adults, especially if they are female and low educated (primary education or junior high school). Therefore several specifications have been estimated: (i) young versus adults; (ii) young females versus adult females; (iii) young with low education versus adult with low education.

Furthermore, it is questionable whether the adults are a good control group. The employment experience of young and adult individuals is likely to be different beyond the wage policy, in particular the seasonal dynamics are more marked for the young. Therefore, we include controls for young specific seasonality in all specifications. ${ }^{38}$ In a fourth specification, the control group is refined by limiting to young adults, i.e. individuals aged between 25 and 34 years old.

Another issue is the definition of changes in the minimum wage. Table 2 shows that during Aznar's mandate, the real minimum wage moved very little, whereas it increased significantly when Zapatero came into power. We may expect the marginal impact of an increase in the minimum wage to be different in the two periods, because of nonlinearity in the effects of the policy on employment. ${ }^{39}$ Since the variable $E_{M W}$ includes both small (Aznar period) and large (Zapatero period) variations in the minimum wage, estimates could be biased. In order to account for the nonlinearity, all estimates have been replicated substituting $E_{M W}$ with $Z_{M W}$. The latter variable considers as expected variations only the substantial increases in the minimum wage occurred in the first quarter of 2005, 2006 and 2007. This means that we are assuming that the small movements arranged by the right wing or due uniquely to inflation have no effect on employment nor flows. ${ }^{40}$

\section{Empirical results}

Marginal effects of a ten percent increase in the minimum wage on the average individual are shown in Tables 4 to 11; standard errors are clustered over time and region. ${ }^{41}$ Each table is divided into four panels, one for each definition of treatment and control groups: (i) young versus adults; (ii) young females versus adult females; (iii) young with low education versus adult with low education; (iv) young versus young adults. The first column includes only the contemporaneous effect of the minimum wage, the dynamics are added in column (2) to (5). The length of the dynamic effect is set at 1 and 2 quarters in (2) and (3) respectively. In order to avoid the overlapping between $E_{M W-p r e 2}$ and $E_{M W-p o s t 2}$, the specification in

\footnotetext{
${ }^{38}$ Young specific seasonality is accounted by a set of dummies, $Y Q i$ with $i=1, . ., 4$, that are equal to 1 if the individual is young in quarter $i$ and 0 otherwise.

${ }^{39}$ Card and Krueger (1995) argue that only substantial variation in the minimum wage are likely to affect employment, therefore small variations should not be used in empirical analysis.

${ }^{40}$ Note that the estimate of equation 25 does not suffer from inconsistency of standard errors because the treatment, i.e. the minimum wage variation, is not serially correlated. See Bertrand, Duflo, and Mullainathan (2004).

${ }^{41}$ Estimates for the full set of regressors are not included here but available upon request.
} 
column (4) accounts for 1 quarter ex-ante effect and 2 quarters ex-post effect, while the lengths of the ex-ante and ex-post dynamics are, respectively, 2 and 1 quarters in column (5).

As anticipated in the previous Section, for each specification two regressions have been estimated: using $E_{M W}$ as the expected-policy variable (Tables 4,6, 10), and using $Z_{M W}$ (Tables $5,7,8,9,11$ ). In the following, we discuss the results of the latter regression. Estimates of the former one are qualitatively similar.

The influence of expectations on the disemployment effect is identified comparing the change in flows and employment probability preceding unexpected and expected variations in the minimum wage.

\subsection{Employment probability}

We start with employment probability. Our model predicts a decrease in employment at the time of the minimum wage increase. Furthermore transitions are expected in the following period and, if the policy is expected, in the preceding quarters.

Main results are reported in Table 5. We control for time effects, young seasonality, region, gender, marital status and education.

When we use the broader definition of the control groups, in the first three panels, we do not get any significant coefficient. The minimum wage policy seems not to have any impact nor dynamic effect on employment, regardless of expectations. However significant results are obtained once we restrict the sample to individual aged less than 35 . The magnitude of the coefficients and their precision increase in the last panel, young versus young adult. This is not surprising since the control group is now closer to the treated; and the effect of the policy is not blurred by the differences between young and adults.

With regard to the expected policies, $Z_{M W}$, we find a negative employment effect on impact and along time. A 10 per cent increase in the minimum wage decreases employment probability by around 4.9 per cent on impact. The magnitude of the dynamic effects depends on the specification.

The estimates in column (2) give significant pre and post 1 quarter effects of 4.5 and 7.1 per cent, respectively. When the length is extended to two quarters, column (3), both effects decreases and the ex-ante effect becomes only marginally significant (pvalue: 12\%). The lower precision and magnitude of $Z_{M W-p r e 2}$ could be due either to the confounding effect of $Z_{M W-p o s t 2}$ or to the shorter length of the ex-ante dynamics. In the former case, shortening the ex-post effect to $Z_{M W-p o s t 1}$ (column (5)) should result in a higher and significant coefficient for $Z_{M W-p r e 2}$. In the latter, the correct specification would correspond to column (4) and we would observe a significant $Z_{M W-p r e 1}$ and an increase in $Z_{M W-p o s t 2}$ with respect to column (3). The results in column (4) and column (5) contradict the confounding effect and support the idea of a short anticipation effect. Estimates in column (4) shows that the employment fall by 4.7 per cent in the quarter preceding the policy, and by 6.7 per cent in the following two quarters. The effects of the unexpected policy are mostly negative but never statistically significant.

Note that all the estimated effects are measured with respect to the pre-expectations period, state 0 in the model. This means that the effects are not additive but one should read, for instance, results in column (4) as: 
- ex-ante effect: before the actual minimum wage policy employment decreases by 4.7 per cent

- on impact effect: at the time of the policy employment probability is lowered by 4.9 per cent with respect to state 0 , i.e. the additional on impact effect is 0.2 per cent

- ex-post effect: after the policy employment probability is 6.7 percentage point lower, i.e. the additional ex-post effect is 1.8 per cent.

Applying the traditional approach to these data, one would estimate the variation in employment probability from the period just before the policy to the following period. Then, the estimated on impact plus ex-post effect would be 2 per cent, whereas the true overall effect is 6.7 per cent. ${ }^{42}$

\subsection{Flows out of employment}

Regressions in Tables 6 and 7 compare the flows out of employment following expected and unexpected changes in the minimum wage, for the treatment and the control group. All specifications control for time effects, young specific seasonality, region, gender, marital status, education, contract type, working day, sector, occupation and whether the individual attended any courses (education or training) during the last month. Results are similar in the two tables; we will focus on Table 7 only, comparing $U_{M W}$ with $Z_{M W}$. Following the same reasoning outlined in the previous Section, we can show that the best specification of the dynamics corresponds to column (4).

The upper panel shows results for young versus adult persons. In line with the model prediction, the estimated on impact effect of the increase in the minimum wage is significantly positive for both expected and unexpected policies. A 10 per cent unexpected increase in the minimum wage is associated with an increase in job separation probability by 2.4 per cent, while the effect is around 5.7 per cent in case if an expected change. Furthermore, the expected policies have significant ex-ante and ex-post effects with magnitude, respectively, of 3.9 and 4.9 percentage points. The positive difference between the on impact and ex-post effect corresponds to the spike in job destruction described in the model.

Regressions in the second panel compare young females with adult females. Previous results are confirmed: the on impact effect is positive and strongly significant for both policies, around 4 per cent; and $Z_{M W}$ displays dynamics of similar magnitude. Estimates in the third panel, young with low education versus adult with low education, are still positive but most of the on impact effect of $U_{M W}$ is no longer significant.

The last panel, young versus young adults, gives results similar to the first panel. The on impact effects of $U_{M W}$ and $Z_{M W}$ are, respectively, 3 and 5.6 percentage points; the expected policy is associated with a significant ex-ante effect, 4.1, and ex-post effect, 5.4. Ignoring the anticipation effect, the overall disemployment effect would be 1.3 instead than 5.4 per

\footnotetext{
${ }^{42}$ Actually, the estimated on impact plus ex-post effect could differ from 2 per cent, due to the underlying misspecification. The difference in difference approach is based on the common trend hypothesis, i.e. the treatment and the control group are assumed to follow the same trend before the treatment takes place. Hence, if there is an ex-ante effect, the two groups would divert even before the treatment takes place violating the common trend hypothesis.
} 
cent. Surprisingly the unexpected policy is found to have a negative ex-post effect, but the coefficient is small, 1.3 per cent, and marginally significant.

Tables 8 and 9 report estimates associated with flows out of temporary and permanent employment. Estimates show that the increase in job separations found in Table 7 is led by the flows out of temporary employment, while permanent workers are not affected by the minimum wage policy. ${ }^{43}$ The probability of losing a temporary job for young workers as opposed to adults increases by 4.2 per cent at the time of an unexpected policy and by 7 per cent at the time of an expected policy. The anticipation effect of $Z_{M W}$ is statistically and economically significant, with magnitude 4.7 per cent; the ex-post effect amounts to 6.3 percentage points. Findings are robust to different specifications of the treatment and control groups.

All regressions includes several control variables. Time and regional dummies are mostly significant. Young workers are more likely to separate; their probability to exit employment is 1 to 3 per cent higher than adults. Being female increases this probability by another 2 per cent. The characteristics of the employment relationship also matters: part time workers are associated with higher mobility and, not surprisingly, temporary contracts entail greater separation rates. On the other side, education reduces job exit. Both positive and negative effects are somewhat stronger for temporary workers, and weaker for permanent ones.

\subsection{Flows into employment}

According to the model, higher labor cost should lead to lower flows into employment, but estimates in Table 11 are often not significant.

The on impact effect of both expected and unexpected policies is statistically null in most specification. In the upper panels, young versus adults and young females versus adult females, the coefficient associated with $U_{M W}$ is positive and significant at 10 per cent level in columns (1) and (2), but the effect fades away when more dynamics is added and it is never significant in the lower panels. These findings help explaining the not significant employment effect in Section 6.1. The unexpected policy had a positive impact on job destruction, but it was counterbalanced by stable or rising inflows.

The length of the dynamics is not as clear as in the previous regressions. The coefficients associated with $Z_{M W-p r e}$ and $Z_{M W-p o s t}$ are mostly significant when controlling for 1quarter pre and post effects. Extending the length of the dynamics, the ex-post effect decreases and the ex-ante effect loses significativity, as in the regressions on employment probability and outflows. The results in column (5) contradict the confounding hypothesis, i.e. the lower precision and magnitude of $Z_{M W-p r e 2}$ is not due to the overlap with $Z_{M W-p o s t 2}$, for the same reason discussed before. On the other side, shortening the length of the ex-ante dynamics (column (4)) leads to results very similar to column (2). These results, together with the lack of significativity of the on impact effect, suggest that dynamic effects are relatively short

\footnotetext{
${ }^{43}$ The different effect of the minimum wage policy on workers with different employment contract cannot be entirely traced back to the role of firing costs. On one side, employment protection may prevent permanent workers to be dismissed by increasing the adjustment cost with respect to temporary workers. The counterbalancing effect of EPL on the disemployment impact of the minimum wage is claimed also by Neumark and Wascher (2004). On the other side, the productivity distribution may differ: temporary jobs may be, on average, less productive, hence a higher share would fall under the job destruction threshold.
} 
and concentrated ex-post. Depending on the definition of the treatment and control group, the overall effect on inflows ranges between -4.6 and -5.7 percentage points.

All specifications control for gender, education, time effect, region, search activity, last sector of occupation and last job. Not surprisingly, the young have greater probability to enter a job. Females are associated to lower inflows by 6 per cent. Adopting and active method of search - such as inquiring the job centre, or private employment agencies, contacting directly employers, etc. - increase the probability of finding a job. Education has a positive effect as well.

\subsection{Discussing the results}

We claim the disemployment effect of the minimum wage to have different dynamics effects depending on whether it is expected or not. In particular, our model predicts: (i) expected policies have an ex-ante effect on employment and flows; (ii) the on impact plus ex-post effect underestimate the overall employment effect of expected policies; (iii) the ex-post effect is lower the higher are expectations.

Our results chiefly confirm the model. The anticipation effect is mostly significant when associated to expected policy and the result is robust to many specification; while $U_{M W-p r e}$ is always statistically null. The magnitude of the ex-ante effect is economically significant and comparable to the on impact and ex-post effect. For instance, let us consider the specification comparing young with young adult: an expected 10 per cent increase in the minimum wage reduces the employment probability ex-ante by 4.7 per cent, flows out of employment increases by 4.1 per cent (by 6.2 per cent when considering flows out of temporary jobs), job creation decreases by 2.7 per cent, although the coefficient is not significant at 10 per cent level. The ex-post effects are, respectively, -6.7 per cent, 5.4 per cent $(+7.7$ for temporary workers), -4.8 per cent. Hence, failing to account for expectations would lead to an important underestimate of the employment effect of the minimum wage. The overall effect is measured by the coefficient of $Z_{M W-p o s t}$, whereas the on impact plus ex-post effect is given by $Z_{M W-p o s t}-Z_{M W-p r e}$. Numerically, in the young versus young adult specification, this would mean that:

- employment: the overall effect is a decrease in employment probability by 6.7 per cent; the on impact plus ex-post effect amounts to -2 per cent;

- outflows: the overall effect is +5.4 ; without accounting for expectations, the effect is -1.3 per cent $(5.4-4.1)$;

- inflows: the overall effect is -4.8 ; the on impact plus ex-post effect account for -2.1 per cent $(4.8-2.7)$.

The standard approach would therefore miss most of the employment effect of the minimum wage policy.

The third prediction is not met by the data: we find no evidence of larger ex-post effects associated to the unexpected policy as opposed to the expected policies. Instead, $U_{M W}$ has no significant ex-post effect on employment, nor on flows, or only small and marginally significant effects. The lack of impact of the unexpected policy cannot be explained in the 
framework proposed in Section 4. But it has to be stressed that our model abstracts from the workers' behavior. A matching model including the workers' decision about the optimal search effort would be able to reproduce these results. ${ }^{44}$ The rise in the minimum wage may induce agents to exert more effort in looking for a better paid job, thus increasing the efficiency of the match process and counterbalancing the lower vacancy posting. The evolution of participation rates goes in this direction (Figure 6). Over the period 2001-2004, activity rate was increasing for both young and adult individuals. The youth's participation rate was, on average, 47.7 per cent in 2001-2003; then it jumped from 49.2 in 2004 to 52.1 in 2005; whereas the adult's participation rate moved only slightly from 80.6 to 80.9 per cent. The substantial rise in participation at the beginning of Zapatero mandate suggests that young individuals reacted to Zapatero election and the rise in the minimum wage by participating more and more effectively in the labor market. Higher participation has the same effect on flows and employment than greater search effort and may account for the lack of significant impact of $U_{M W}$. Instead, the positive effect on participation is weaker after 2005 and, although it may account for the small effect of the minimum wage on job creation, it cannot counterbalance the rise in job destruction and the fall in employment associated with the expected policies.

\section{Conclusion}

The empirical literature on minimum wages is characterized by controversial results. It is far from clear whether this policy has a negative effect on employment or not. Nor economic theory provides a clear prediction. This paper contributes to the debate by proposing a mechanism capable of reconciling conflicting findings. The key ingredient is the introduction of expectations in the analysis of the minimum wage policy.

The role of expectations in shaping the behavior of economic agents has been extensively studied in a variety of subject, but never in relation with the minimum wage. In many countries the law determines the level of the minimum wage and the frequency of its revisions; often it also fixes criteria to be used in updating the minimum wage, such as the dynamics of prices and productivity. Hence, the minimum wage policy can often been foreseen and expectations about future changes may affect employment over time.

We propose a search and matching model enriched by expectations and shows that, when the change in the minimum wage is expected, the disemployment effect observed after the policy is only a part of the overall effect, and it is smaller the higher is the likelihood associated with the policy. The effect of higher future labor costs is partly anticipated by agents, then employment decreases even before the minimum wage actually increases and the residual ex-post effect may be small and hard to identify in the empirical estimates. Since the literature has considered mainly expected policies, the lack of robustness of the estimated ex-post disemployment effect is not surprising.

A clear case of unexpected variation in the minimum wage is the increase operated in Spain in July 2004 by the newly elected Socialist Party. We use this natural experiment to test the validity of our model by comparing the effects of the unexpected policy with those of the expected policies. The minimum wage variation is allowed to affect employment

\footnotetext{
${ }^{44}$ See for instance the model proposed in Flinn (2006).
} 
and job flows both at the time of the policy, before and after the policy. In order to net out confounding factors, we implement a difference in difference approach along several specifications: young versus adults, young females versus adult females, young with low education versus adult with low education, young versus young adults.

Our results confirm the relevance of the anticipation effect. The expected changes in the minimum wage implemented in Spain between 2005 and 2007 had a statistically and economically significant ex-ante effect on employment probability and job destruction, as opposed to the unexpected policy. The standard approach, ignoring the anticipation effect, would lead to a severe underestimate of the overall impact. On the other side, the unexpected policy had only a minor impact on employment and flows. Empirical evidence suggest that young individuals reacted to Zapatero election and the rise in the minimum wage by participating more and more effectively in the labor market. The rise in the participation rate partly counterbalanced the potentially negative effect of the policy. 


\section{References}

Ai, C. and E. C. Norton (2003). Interaction Terms in Logit and Probit Models. Economic Letters 80, 123-129.

Bertrand, M., E. Duflo, and S. Mullainathan (2004, February). How Much Should We Trust Differences-in-Differences Estimates? The Quarterly Journal of Economics, 249275 .

Boadway, R. and K. Cuff (2001). A Minimum Wage Can Be Welfare-Improving and Employment-Enhancing. European Economic Review 45, 553-576.

Brandolini, A., P. Cipollone, and E. Viviano (2006, March). Does the ILO Definition Capture All Unemployment? Journal of the European Economic Association 4(1), $153-179$.

Brown, C., C. Gilroy, and A. Kohen (1982). The Effect of the Minimyn Wage on Employment and Unemployment. Journal of Economic Literature 20, 487-528.

Cahuc, P. and A. Zylberberg (2004). Labor Economics. Cambridge, Massachusetts: The MIT Press.

Card, D. (1992, October). Using Regional Variation in Wages to Measure the Effects of the Federal Minimum Wage. Industrial and Labor Relations Review 46(1), 22-37.

Card, D. and A. B. Krueger (1994, December). Minimum Wages and Employment: A Case Study of the Fast-Food Industry in New Jersey and Pennsylvania. American Economic Review 84(5), 772-793.

Card, D. and A. B. Krueger (1995). Mith and Measurement: The New Economics of the Minimum Wage. Princeton, NJ: Princeton University Press.

Card, D. and A. B. Krueger (2000, December). MinimumWages and Employment: A Case Study of the Fast-Food Industry in New Jersey and Pennsylvania: Reply. American Economic Review 90(5), 1397-1420.

Dolado, J., F. Kramarz, S. Machin, A. Manning, D. Margolis, and C. Teulings (1996, October). The Economic Impact of Minimum Wages in Europe. Economic Policy 23(35), 318-372.

Flinn, C. J. (2006, July). Minimum Wage Effects on Labor Market Outcomes under Search, Matching, and Endogenous Contact Rates. Econometrica 74(4), 1013-1062.

ILO (2006). Minimum Wages Policy. Information Sheet (W-1).

Lucas, R. E. J. (1972). Expectations and the Neutrality of Money. Journal of Economic Theory 4 (2), 103-124.

Manning, A. (1995, November). How Do We Know That Real Wages are Too High? Quarterly Journal of Economics 110(4), 1111-1125.

Manning, A. (2003). The Real Thin Theory: Monopsony in Modern Labour Markets. Labour Economics 10, 105-131.

Manning, A. (2004). Monopsony and the Efficiency of Labour Market Interventions. Labour Economics 11, 145-163. 
Molina Romo, Ó. (2003). The Politics of Wage Bargaining Reform in Italy and Spain 1991-2001. EUI Working Paper SPS (14), 1-45.

Molina Romo, Ó. (2004). Still the Century of Political Exchange? Policy Adjustment and Political Exchange in Southern Europe. EUI Working Paper SPS (14), 1-53.

Montalvo, J. G. (2006). Voting After the Bombing: Can Terrorist Attacks Change the Outcome of Democratic Elections? Universitat Pompeu Fabra Working Paper (1000).

Mortensen, D. T. and C. A. Pissarides (1994, July). Job Creation and Job Destruction in the Theory of Unemployment. The Review of Economic Studies. 61(3), 397-415.

Neumark, D. and W. Wascher (1992, October). Employment Effects of Minimum and Subnminimum Wages: Panel Data on State Minimum Wage Laws. Industrial and Labor Relations Review 46(1), 55-81.

Neumark, D. and W. Wascher (1995). Minimum-Wage Effects on School and Work Transitions of Teenagers. The American Economic Review 85(2), 244-249.

Neumark, D. and W. Wascher (2000, December). Minimum Wages and Employment: A Case Study of the Fast-Food Industry in New Jersey and Pennsylvania: Comment. The American Economic Review 90(5), 1362-1396.

Neumark, D. and W. Wascher (2004, January). Minimum Wages, Labor Market Institutions, and Youth Employment: A Cross-National Analysis. Industrial and Labor Relations Review 57(2), 223-248.

Neumark, D. and W. Wascher (2007a, January). Minimum Wages and Employment. IZA Discussion Paper (2570).

Neumark, D. and W. Wascher (2007b, February). Minimum Wages, the Earned Income Tax Credit, and Employment: Evidence from the Post-Welfare Reform Era. NBER Working Paper (12915), 1-37.

Neumark, D. and W. L. Wascher (2002, Winter). State-Level Estimates of Minimum Wage Effects: New Evidence and Interpretations from Disequilibrium Models. Journal of Human Resources 37(1), 35-62.

Norton, E. C., H. Wang, and C. Ai (2004). Computing Interaction Effects and Standard Errors in Logit and Probit Models. The Stata Journal 4 (2), 154-167.

OECD (1998). Making the Most of the Minimum: Statutory Minimum Wages, Employment and Poverty, Chapter 2, pp. 31-77. OECD.

Pissarides, C. A. (2000). Equilibrium Uneployment Theory. Cambridge, Massachusetts: The MIT Press.

Portugal, P. and A. R. Cardoso (2006). Disentangling the Minimum Wage Puzzle: An Analysis of Worker Accessions and Separations. Journal of the European Economic Association 4 (5), 988-1013.

Puhani, P. A. (2008). The Treatment Effect, the Cross Difference, and the Interaction Term in Nonlinear "Difference-in-Differences" Models. IZA Discussion Paper (3478).

Rebitzer, J. B. and L. J. Taylor (1996). The Consequences of Minimum Wage Laws: Some New Theoretical Ideas. Journal of Public Economics 56, 245-256. 
Figure 1. Job values pre and post minimum wage variation in a model with expectations.

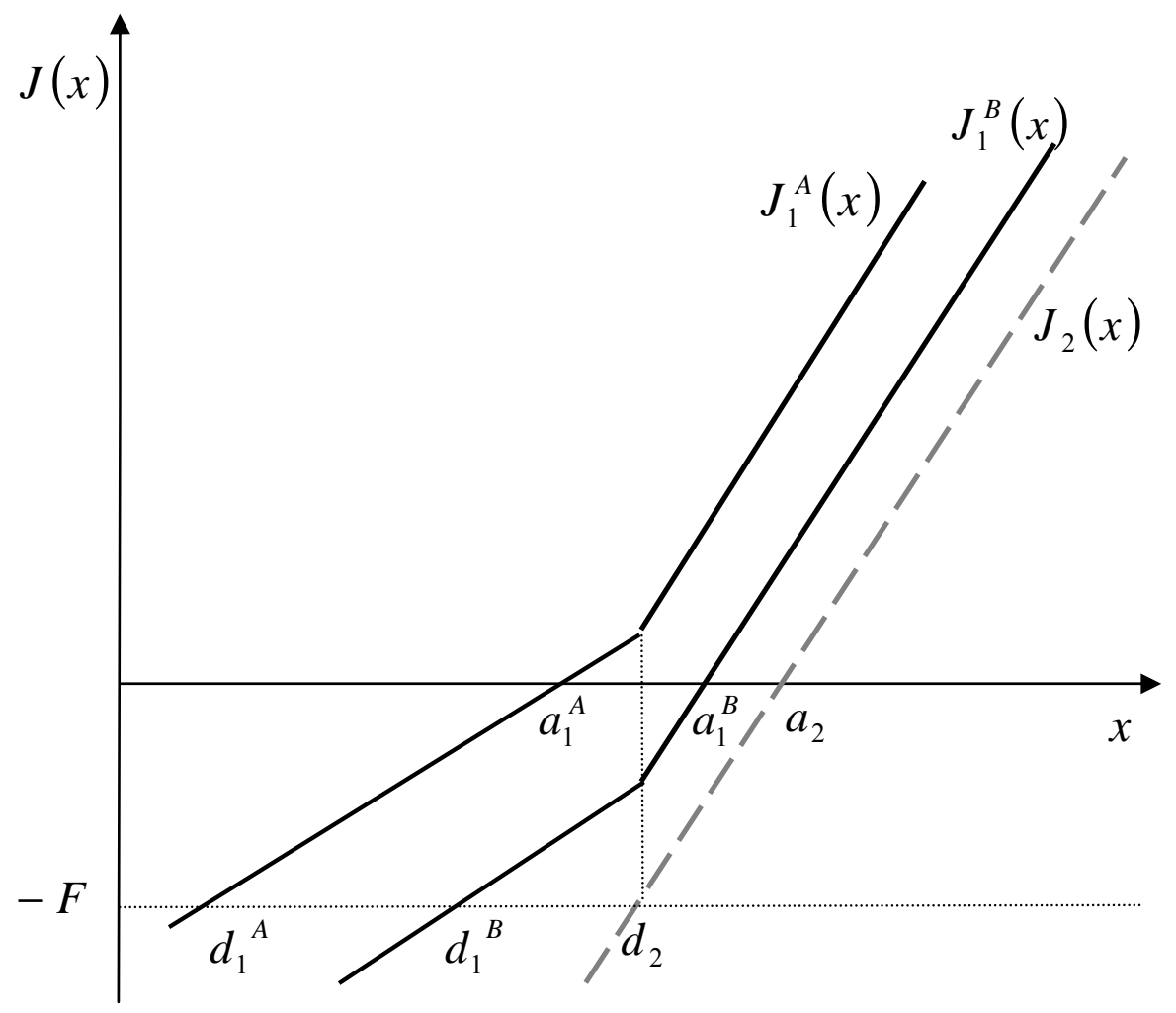

$J_{1}(x)$ is the value of a job with productivity $x$ in state 1 (wage $w=w_{1}$; expectations $\varphi=\varphi_{1}$ ) $J_{2}(x)$ is the value of a job with productivity $x$ in state 2 (wage $w^{\prime}=w_{2}$; expectations $\varphi=\varphi_{2}=0$ ) $a$ is the productivity level such that $J(x)$ is null; it is called hiring standard.

$d$ is the productivity level such that $J(x)$ is equal to $-F$, the firing cost; it is called job destruction threshold.

The position of $J_{1}(x)$ depends on the value of the primitive parameters. Here, two cases are depicted: $\mathrm{A}$ and $\mathrm{B}$. When firing costs are low with respect to the minimum wage variation, case $\mathrm{A}$, the hiring standard $a_{1}$ is lower than the job destruction threshold in state $2, d_{2}$. Otherwise, case $\mathrm{B}$, the hiring standard $a_{1}$ is higher than $d_{2}$. 
Figure 2. Unemployment dynamics.

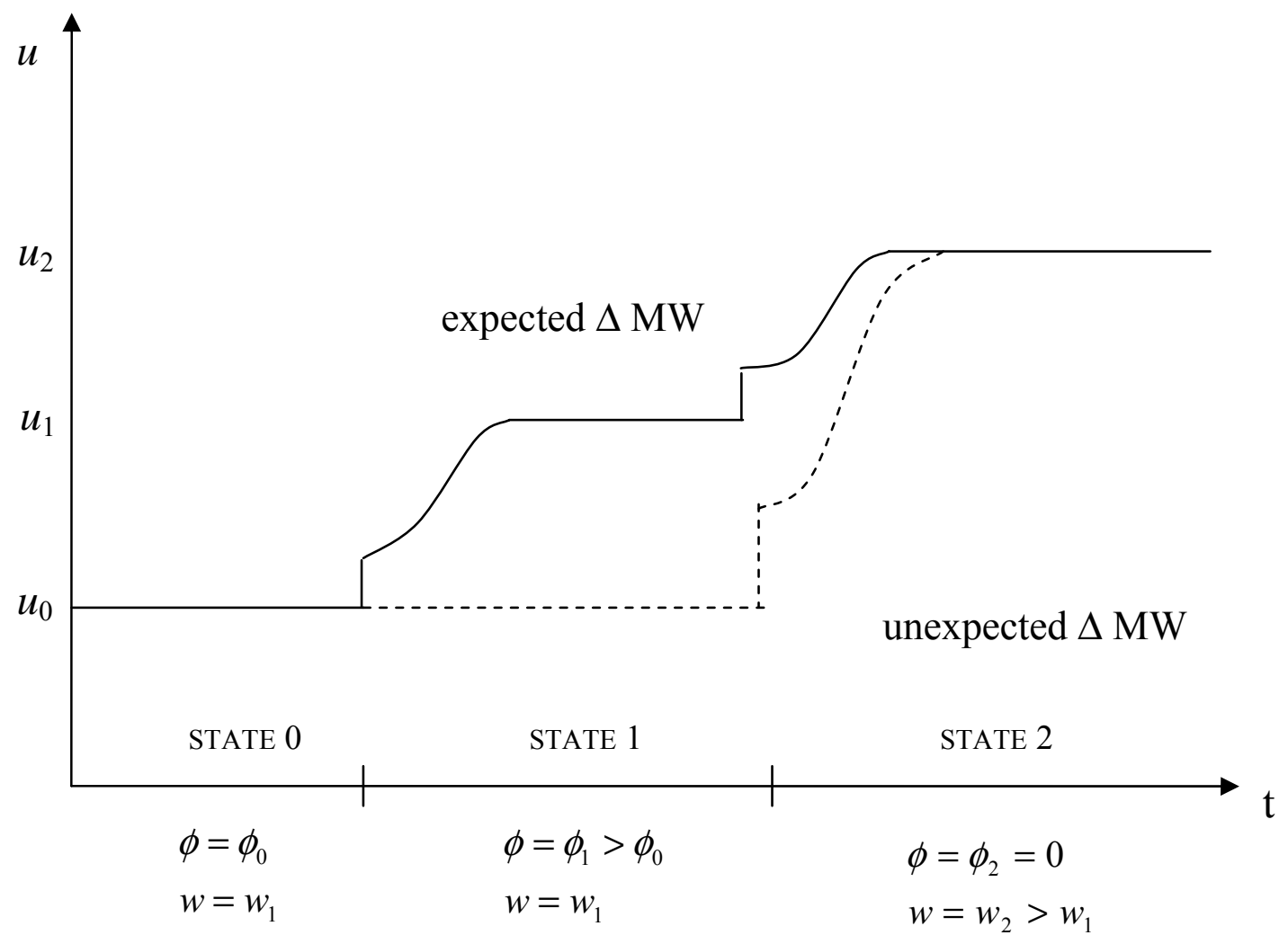

The continuous line represents the dynamics of unemployment along state 0 , state 1 and state 2 in case of an expected change in the minimum wage.

The discontinuous line depict the dynamics of unemployment along state 0 and state 2 in case of an unexpected increase in the minimum wage. 
Figure 3. Job creation and job destruction dynamics.
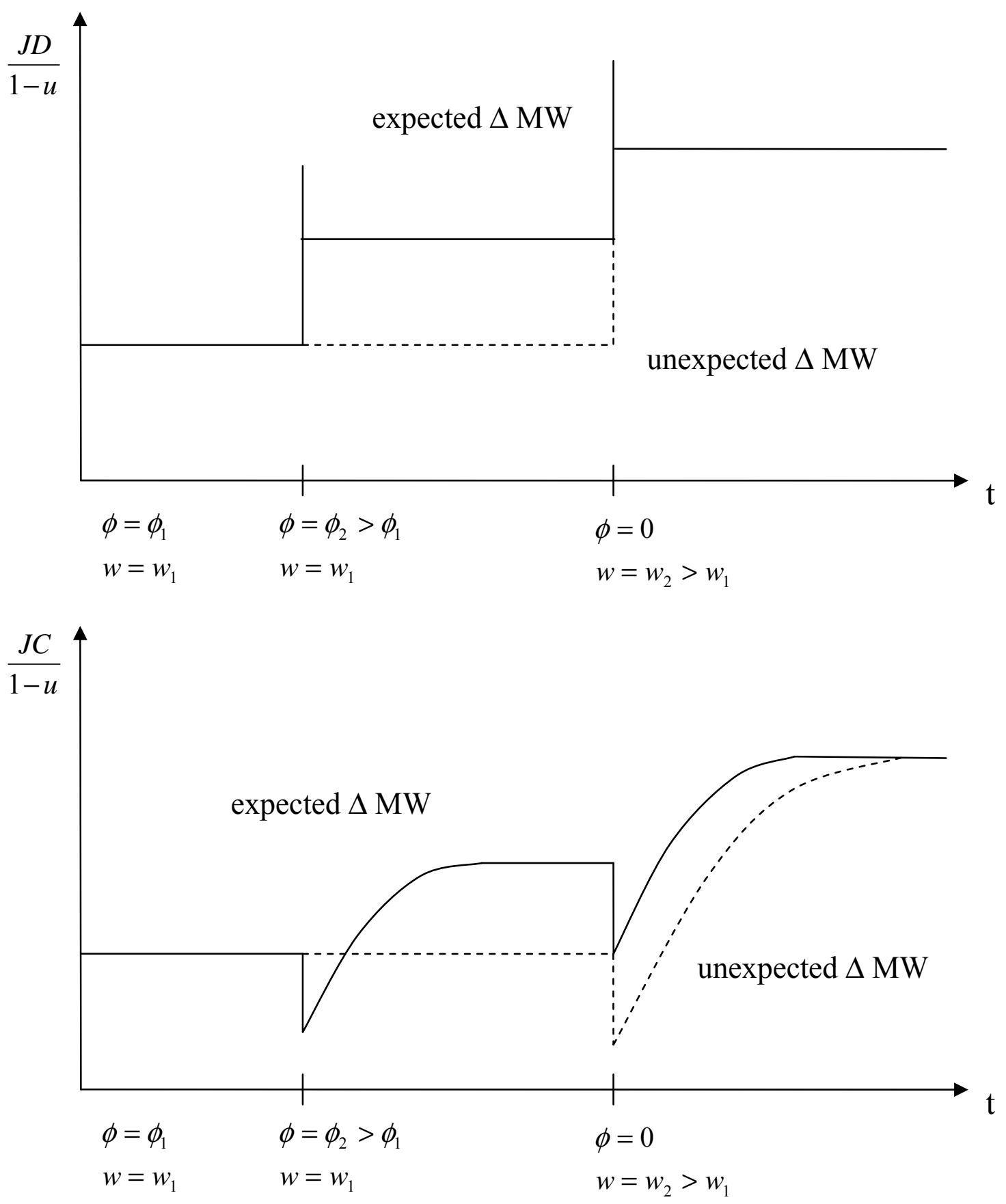

The continuous line represents the dynamics of the JD (JC) rate along state 0 , state 1 and state 2 in case of an expected change in the minimum wage.

The discontinuous line depict the dynamics of the JD (JC) rate along state 0 and state 2 in case of an unexpected increase in the minimum wage. 
Figure 4. Job finding rate dynamics.

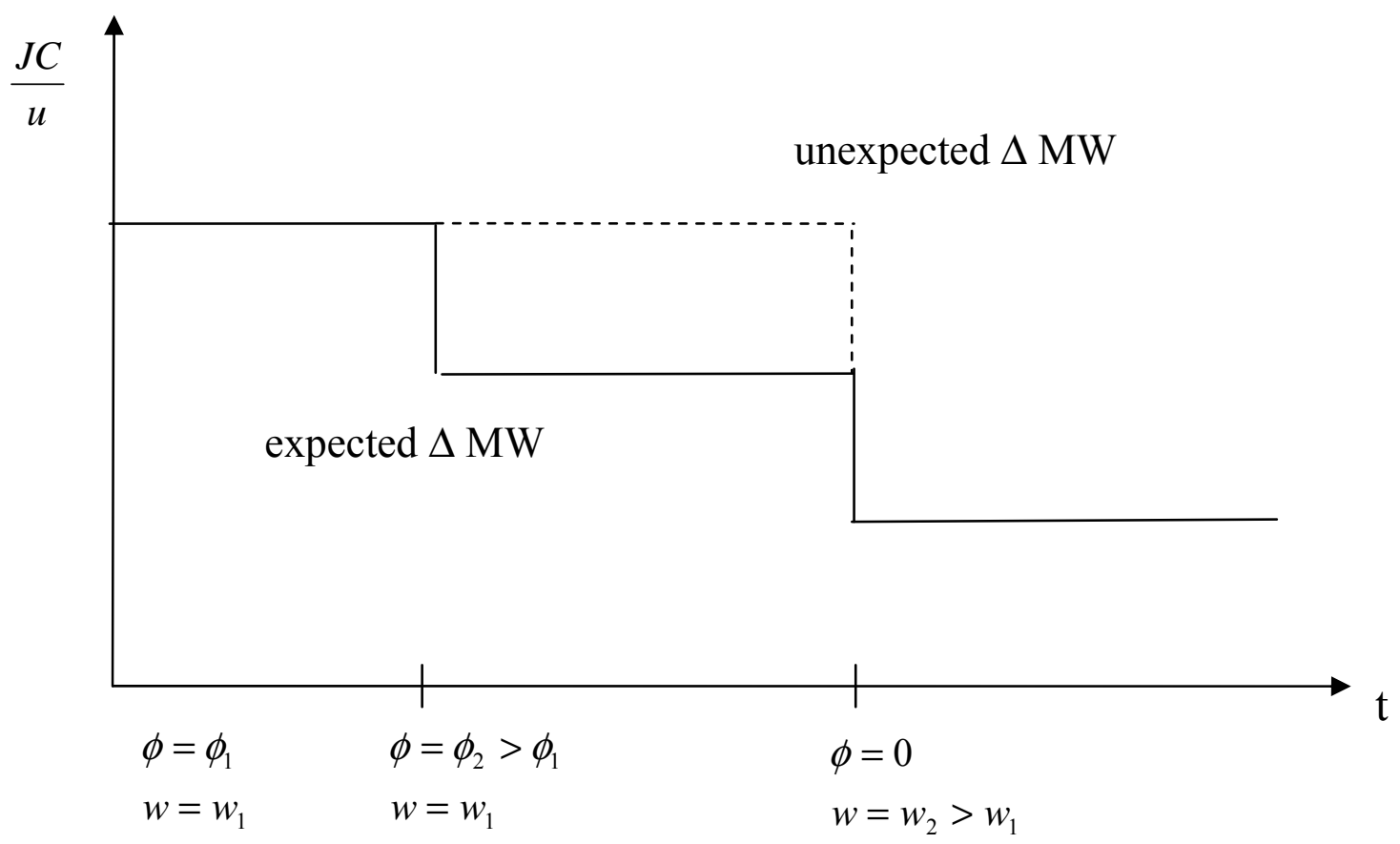

The continuous line represents the dynamics of the job finding rate along state 0 , state 1 and state 2 in case of an expected change in the minimum wage.

The discontinuous line depict the dynamics of the job finding rate along state 0 and state 2 in case of an unexpected increase in the minimum wage. 
Figure 5. Wage structure in Spain, 2002.

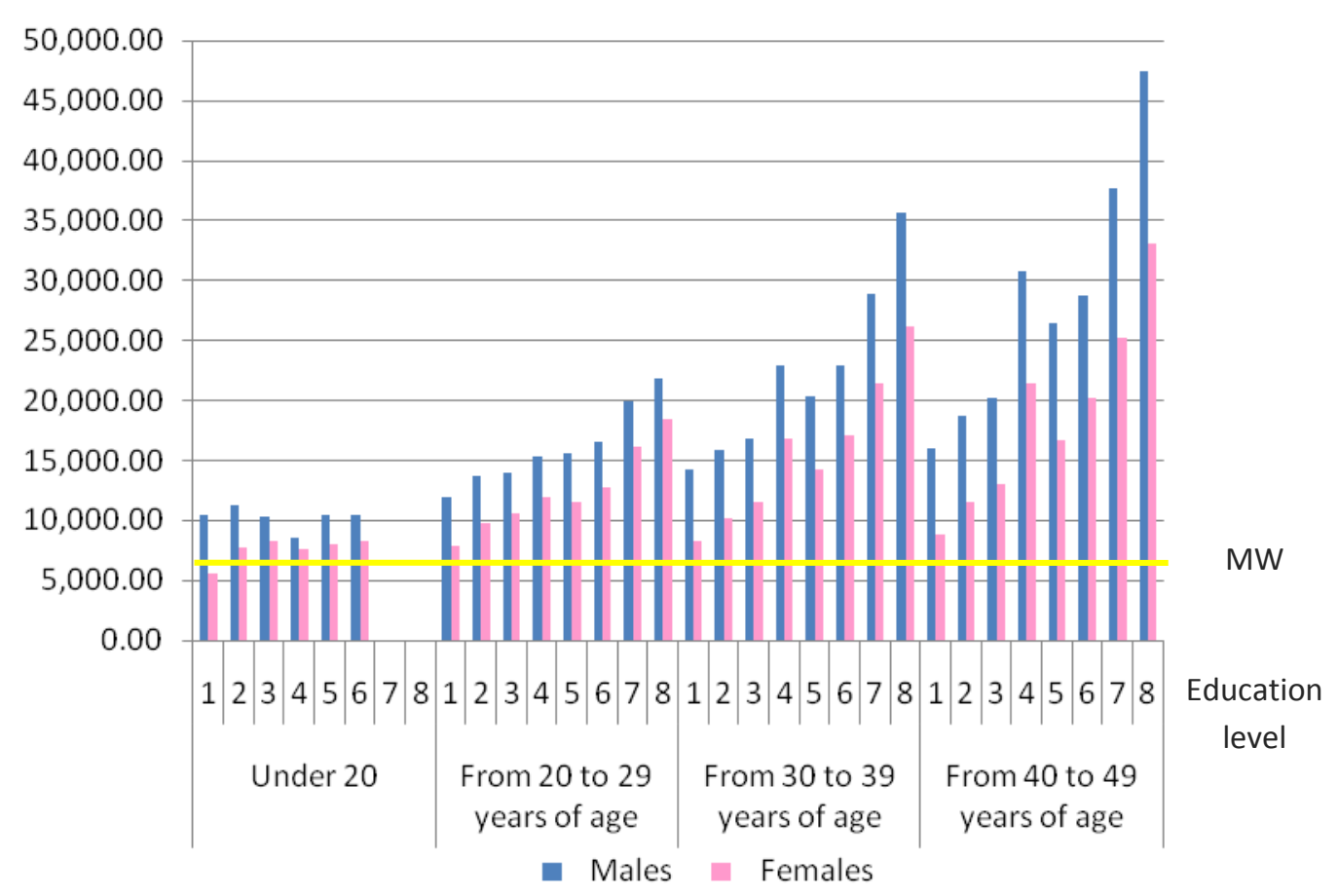

Source: INE, Wage Structure Survey (2002).

Figure 6. Labor force participation rate in Spain by age.

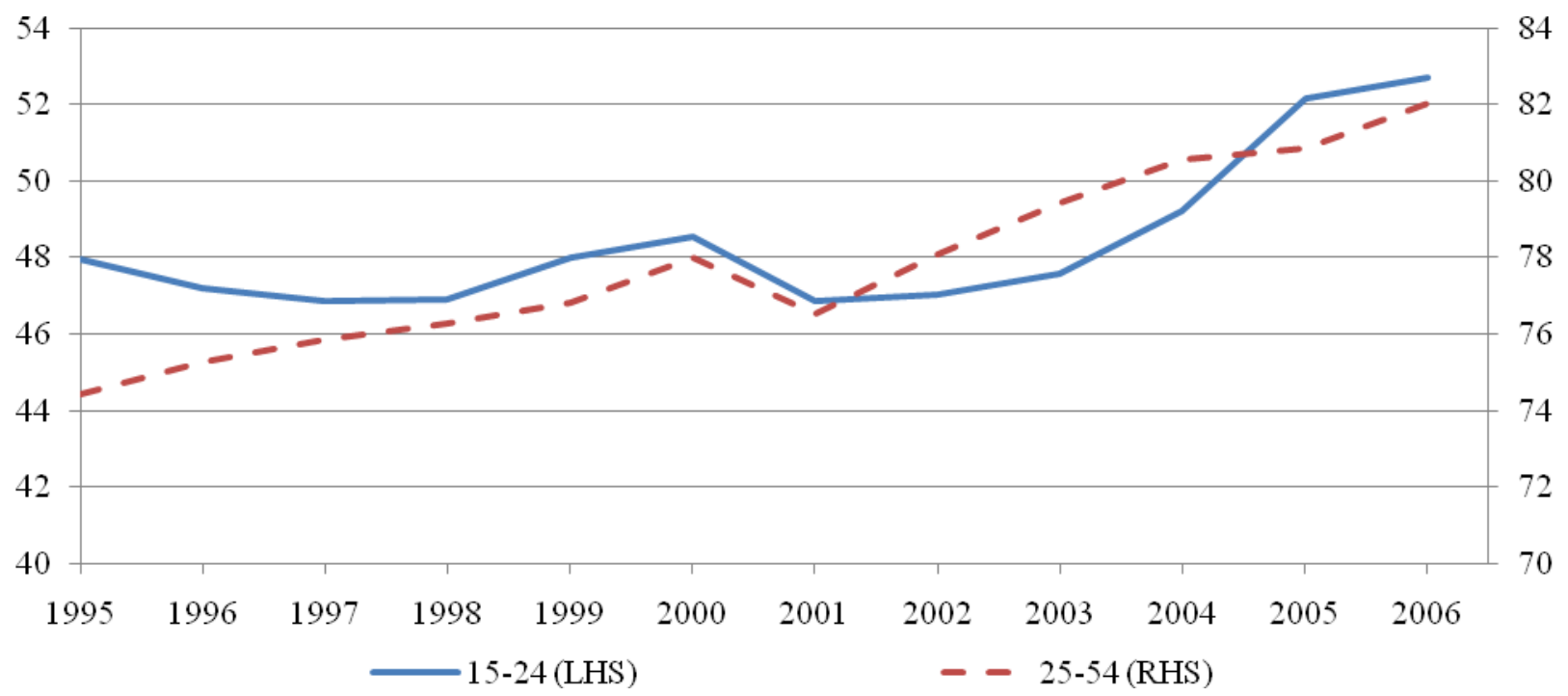

Source: INE, Labour Force Survey 
Table 1. The minimum wage policy in OECD countries.

\begin{tabular}{lll}
\hline \hline Country & Method for setting & Adjustment provision \\
\hline Australia & Statute & Yearly \\
Belgium & Negotiated & Yearly \\
Canada & Statute & Not defined \\
France & Statute & At least yearly \\
Germany & Negotiated & Usually every 12 months \\
Greece & Negotiated & Twice a year \\
Italy & Negotiated & Every two years \\
Japan & Statute & When necessary \\
Luxemburg & Statute & Twice a year \\
Netherlands & Statute & Twice a year \\
New Zealand & Statute & Yearly \\
Portugal & Statute & Yearly \\
Spain & Statute & Yearly \\
Sweden & Negotiated & Usually every 3 years \\
United Kingdom & Statute & Not defined \\
US & Statute & Not defined \\
\hline \hline
\end{tabular}

Source: ILO database on the minimum wage policy. 
Table 2. Evolution of the minimum wage in Spain

\begin{tabular}{|c|c|c|c|c|}
\hline $\begin{array}{l}\text { Date of coming } \\
\text { into effect }\end{array}$ & Minimum wage & $\begin{array}{l}\text { Variation over } \\
\text { previous MW }\end{array}$ & $\mathrm{CPI}^{1}$ & $\begin{array}{c}\text { Variation real } \\
\text { MW }\end{array}$ \\
\hline 6-1-1980 & 136.85 & 10.2 & 15.56 & -5.36 \\
\hline 6-1-1981 & 153.98 & 12.5 & 14.54 & -2.04 \\
\hline $1-1-1982$ & 170.93 & 11.0 & 14.41 & -3.41 \\
\hline $1-1-1983$ & 193.29 & 13.1 & 12.17 & 0.93 \\
\hline $1-1-1984$ & 208.79 & 8.0 & 11.28 & -3.28 \\
\hline $1-1-1985$ & 223.40 & 7.0 & 8.81 & -1.81 \\
\hline $1-1-1986$ & 241.25 & 8.0 & 8.79 & -0.79 \\
\hline $1-1-1987$ & 253.33 & 5.0 & 6.10 & -1.1 \\
\hline $1-1-1988$ & 264.69 & 4.5 & 4.41 & 0.09 \\
\hline $1-1-1989$ & 280.55 & 6.0 & 6.22 & -0.22 \\
\hline $1-1-1990$ & 300.57 & 7.1 & 6.99 & 0.11 \\
\hline $1-1-1991$ & 320.04 & 6.5 & 6.18 & 0.32 \\
\hline 1-1-1992 & 338.25 & 5.7 & 6.55 & -0.85 \\
\hline $1-1-1993$ & 351.77 & 4.0 & 4.23 & -0.23 \\
\hline $1-1-1994$ & 364.03 & 3.5 & 5.00 & -1.5 \\
\hline $1-1-1995$ & 376.83 & 3.5 & 4.77 & -1.27 \\
\hline $1-1-1996$ & 390.18 & 3.5 & 3.65 & -0.15 \\
\hline $1-1-1997$ & 400.45 & 2.6 & 2.54 & 0.06 \\
\hline $1-1-1998$ & 408.93 & 2.1 & 1.85 & 0.25 \\
\hline $1-1-1999$ & 416.32 & 1.8 & 1.87 & -0.07 \\
\hline $1-1-2000$ & 424.80 & 2.0 & 2.92 & -0.92 \\
\hline $1-1-2001$ & 433.45 & 2.0 & 3.79 & -1.79 \\
\hline $1-1-2002$ & 442.20 & 2.0 & 2.50 & -0.5 \\
\hline $1-1-2003$ & 451.20 & 2.0 & 3.75 & -1.75 \\
\hline $1-1-2004$ & 460.50 & 2.0 & 2.19 & -0.19 \\
\hline $7-1-2004$ & 490.80 & 6.6 & 2.20 & 4.4 \\
\hline $1-1-2005$ & 513.00 & 4.5 & 1.04 & 3.46 \\
\hline $1-1-2006$ & 540.90 & 5.4 & 4.01 & 1.39 \\
\hline $1-1-2007$ & 570.60 & 5.5 & 2.42 & 3.08 \\
\hline
\end{tabular}

Source: Minimum wage: Ministerio Trabajo y Asuntos Sociales (BOE); CPI: OECD (MEI).

${ }^{1}$ Values in CPI column shows the percentage change of the CPI between two changes in the minimum wage, so that CPI $=6.10$ in $1 / 1 / 1987$ is the variation of the price level between $1 / 1 / 1986$ and $1 / 1 / 1987$; and $C P I=2.20$ in $7 / 1 / 2004$ is the variation of the price level between 1/1/2004 and 7/1/2004. 
Table 3. Composition of the dataset, percentage.

\begin{tabular}{|c|c|c|c|c|}
\hline & $2000-2006$ & 2000 & 2004 & 2006 \\
\hline \multicolumn{5}{|l|}{ Age: } \\
\hline young (16-24) & 13.99 & 15.82 & 13.15 & 12.68 \\
\hline adult $(25-54)$ & 53.94 & 52.52 & 54.25 & 55.29 \\
\hline old (at least 55) & 32.06 & 31.67 & 32.60 & 32.03 \\
\hline \multicolumn{5}{|l|}{ Education: } \\
\hline primary or lower & 37.96 & 42.89 & 36.95 & 32.90 \\
\hline secondary or professional & 41.99 & 39.23 & 42.61 & 44.76 \\
\hline university or higher & 20.05 & 17.88 & 20.44 & 22.34 \\
\hline \multicolumn{5}{|l|}{ Status: } \\
\hline employed & 50.37 & 45.68 & 49.43 & 58.15 \\
\hline temporary $^{1}$ & 32.00 & 32.08 & 30.64 & 34.03 \\
\hline permanent $^{1}$ & 68.00 & 67.92 & 69.36 & 65.97 \\
\hline unemployed & 6.98 & 7.66 & 7.24 & 5.79 \\
\hline \multirow[t]{3}{*}{ out of labor force } & 42.65 & 46.66 & 43.33 & 36.06 \\
\hline & \multicolumn{2}{|c|}{ Young } & \multicolumn{2}{|c|}{ Adult } \\
\hline & 2000 & 2005 & 2000 & 2005 \\
\hline \multicolumn{5}{|l|}{ Education: } \\
\hline primary or lower & 9.88 & 10.53 & 28.83 & 15.58 \\
\hline secondary or professional & 74.75 & 76.09 & 45.61 & 52.93 \\
\hline university or higher & 15.37 & 13.39 & 25.56 & 31.48 \\
\hline \multicolumn{5}{|l|}{ Status: } \\
\hline employed & 32.43 & 37.56 & 65.79 & 72.34 \\
\hline temporary $^{1}$ & 69.57 & 66.73 & 28.38 & 28.59 \\
\hline permanent $^{1}$ & 30.43 & 33.27 & 71.62 & 71.41 \\
\hline unemployed & 12.60 & 10.61 & 9.87 & 6.86 \\
\hline out of labor force & 54.88 & 51.83 & 24.26 & 20.81 \\
\hline \multicolumn{5}{|l|}{ Flows: $^{2}$} \\
\hline employment-employment & 88.25 & 84.24 & 95.91 & 94.77 \\
\hline employment-non employment & 11.75 & 15.76 & 4.09 & 5.23 \\
\hline nonemployment-nonemployment & 91.72 & 86.48 & 91.10 & 84.46 \\
\hline nonemployment-employment & 8.28 & 13.52 & 8.90 & 15.54 \\
\hline
\end{tabular}

Source: Computation based on INE, Enquesta de Población Activa, Anonimizado de Flujos, 2000-2006.

Values are computed as percentages over the number of individuals who answered the relative questions.

${ }^{1}$ Share of employed persons under a temporary/permanent contract.

${ }^{2}$ Share of employed (nonemployed) individuals who are employed/nonemployed in the following quarter. 
Table 4. Employment ( $\mathrm{U}_{\mathrm{MW}}$ vs. $\left.\mathrm{E}_{\mathrm{MW}}\right)$, Probit regression model.

\begin{tabular}{|c|c|c|c|c|c|}
\hline & $(1)$ & $(2)$ & (3) & (4) & (5) \\
\hline \multicolumn{6}{|c|}{ TREATED: Young - CONTROL: Adult } \\
\hline young* $\mathrm{U}_{\mathrm{MW}}$ & $\begin{array}{c}-0.001 \\
{[0.022]}\end{array}$ & $\begin{array}{c}-0.002 \\
{[0.022]}\end{array}$ & $\begin{array}{c}-0.004 \\
{[0.023]}\end{array}$ & $\begin{array}{c}-0.002 \\
{[0.022]}\end{array}$ & $\begin{array}{c}-0.002 \\
{[0.023]}\end{array}$ \\
\hline young* $\mathrm{E}_{\mathrm{MW}}$ & $\begin{array}{c}0.002 \\
{[0.022]}\end{array}$ & $\begin{array}{c}0.004 \\
{[0.023]}\end{array}$ & $\begin{array}{c}0.001 \\
{[0.0235]}\end{array}$ & $\begin{array}{c}0.004 \\
{[0.025]}\end{array}$ & $\begin{array}{c}0.001 \\
{[0.023]}\end{array}$ \\
\hline young* $\mathrm{U}_{\mathrm{MW} \_ \text {pre }}$ & & $\begin{array}{c}0.012 \\
{[0.022]}\end{array}$ & $\begin{array}{c}0.004 \\
{[0.014]}\end{array}$ & $\begin{array}{c}0.012 \\
{[0.022]}\end{array}$ & $\begin{array}{c}0.000 \\
{[0.002]}\end{array}$ \\
\hline young* $\mathrm{U}_{\mathrm{MW} \_ \text {post }}$ & & $\begin{array}{c}-0.006 \\
{[0.023]}\end{array}$ & $\begin{array}{c}0.003 \\
{[0.015]}\end{array}$ & $\begin{array}{c}0.002 \\
{[0.016]}\end{array}$ & $\begin{array}{c}0.000 \\
{[0.002]}\end{array}$ \\
\hline young* $\mathrm{E}_{\mathrm{MW} \_ \text {pre }}$ & & $\begin{array}{c}0.016 \\
{[0.031]}\end{array}$ & $\begin{array}{c}0.006 \\
{[0.023]}\end{array}$ & $\begin{array}{c}0.008 \\
{[0.030]}\end{array}$ & $\begin{array}{c}0.000 \\
{[0.002]}\end{array}$ \\
\hline young* $\mathrm{E}_{\mathrm{MW} \_ \text {post }}$ & & $\begin{array}{c}-0.008 \\
{[0.027]}\end{array}$ & $\begin{array}{c}-0.010 \\
{[0.022]}\end{array}$ & $\begin{array}{c}-0.007 \\
{[0.020]}\end{array}$ & $\begin{array}{l}-0.001 \\
{[0.003]}\end{array}$ \\
\hline Pseudo-R ${ }^{2}$ & 0.237 & 0.237 & 0.237 & 0.237 & 0.237 \\
\hline Observations & 2589914 & 2589914 & 2589914 & 2589914 & 2589914 \\
\hline \multicolumn{6}{|c|}{ TREATED: Young female - CONTROL: Adult female } \\
\hline young* $\mathrm{U}_{\mathrm{MW}}$ & $\begin{array}{c}-0.005 \\
{[0.022]}\end{array}$ & $\begin{array}{l}-0.005 \\
{[0.022]}\end{array}$ & $\begin{array}{c}-0.007 \\
{[0.023]}\end{array}$ & $\begin{array}{c}-0.006 \\
{[0.022]}\end{array}$ & $\begin{array}{c}-0.003 \\
{[0.023]}\end{array}$ \\
\hline young* $\mathrm{E}_{\mathrm{MW}}$ & $\begin{array}{c}-0.007 \\
{[0.022]}\end{array}$ & $\begin{array}{l}-0.013 \\
{[0.022]}\end{array}$ & $\begin{array}{c}-0.004 \\
{[0.023]}\end{array}$ & $\begin{array}{l}-0.005 \\
{[0.024]}\end{array}$ & $\begin{array}{c}-0.014 \\
{[0.022]}\end{array}$ \\
\hline young* $\mathrm{U}_{\mathrm{MW} \_ \text {pre }}$ & & $\begin{array}{c}0.003 \\
{[0.020]}\end{array}$ & $\begin{array}{c}0.000 \\
{[0.013]}\end{array}$ & $\begin{array}{c}0.005 \\
{[0.020]}\end{array}$ & $\begin{array}{c}0.000 \\
{[0.002]}\end{array}$ \\
\hline young* $\mathrm{U}_{\mathrm{MW} \_ \text {post }}$ & & $\begin{array}{c}-0.020 \\
{[0.020]}\end{array}$ & $\begin{array}{c}-0.008 \\
{[0.014]}\end{array}$ & $\begin{array}{c}-0.006 \\
{[0.014]}\end{array}$ & $\begin{array}{c}-0.002 \\
{[0.002]}\end{array}$ \\
\hline young* $\mathrm{E}_{\mathrm{MW} \_ \text {pre }}$ & & $\begin{array}{c}0.004 \\
{[0.028]}\end{array}$ & $\begin{array}{c}0.001 \\
{[0.022]}\end{array}$ & $\begin{array}{c}-0.006 \\
{[0.028]}\end{array}$ & $\begin{array}{l}-0.001 \\
{[0.003]}\end{array}$ \\
\hline young* $\mathrm{E}_{\mathrm{MW} \_ \text {post }}$ & & $\begin{array}{c}-0.029 \\
{[0.025]}\end{array}$ & $\begin{array}{c}-0.023 \\
{[0.021]}\end{array}$ & $\begin{array}{c}-0.022 \\
{[0.019]}\end{array}$ & $\begin{array}{l}-0.004 \\
{[0.003]}\end{array}$ \\
\hline Pseudo-R2 & 0.168 & 0.168 & 0.168 & 0.168 & 0.168 \\
\hline Observations & 1302474 & 1302474 & 1302474 & 1302474 & 1302474 \\
\hline \multicolumn{6}{|c|}{ TREATED: Young low education - CONTROL: Adult low education } \\
\hline young* $\mathrm{U}_{\mathrm{MW}}$ & $\begin{array}{c}-0.002 \\
{[0.028]}\end{array}$ & $\begin{array}{c}-0.001 \\
{[0.028]}\end{array}$ & $\begin{array}{c}-0.001 \\
{[0.030]}\end{array}$ & $\begin{array}{c}-0.003 \\
{[0.028]}\end{array}$ & $\begin{array}{c}0.006 \\
{[0.029]}\end{array}$ \\
\hline young* $\mathrm{E}_{\mathrm{MW}}$ & $\begin{array}{c}0.000 \\
{[0.027]}\end{array}$ & $\begin{array}{c}-0.015 \\
{[0.028]}\end{array}$ & $\begin{array}{l}-0.004 \\
{[0.029]}\end{array}$ & $\begin{array}{c}-0.011 \\
{[0.030]}\end{array}$ & $\begin{array}{l}-0.013 \\
{[0.027]}\end{array}$ \\
\hline young $* \mathrm{U}_{\mathrm{MW} \_ \text {pre }}$ & & $\begin{array}{c}0.001 \\
{[0.027]}\end{array}$ & $\begin{array}{c}-0.005 \\
{[0.018]}\end{array}$ & $\begin{array}{c}0.002 \\
{[0.027]}\end{array}$ & $\begin{array}{l}-0.001 \\
{[0.002]}\end{array}$ \\
\hline young $* \mathrm{U}_{\mathrm{MW} \_ \text {post }}$ & & $\begin{array}{l}-0.006 \\
{[0.031]}\end{array}$ & $\begin{array}{c}0.000 \\
{[0.020]}\end{array}$ & $\begin{array}{c}0.008 \\
{[0.020]}\end{array}$ & $\begin{array}{l}-0.001 \\
{[0.003]}\end{array}$ \\
\hline young* $\mathrm{E}_{\mathrm{MW} \_ \text {pre }}$ & & -0.024 & -0.008 & -0.034 & -0.003 \\
\hline
\end{tabular}




\begin{tabular}{|c|c|c|c|c|c|}
\hline young* $\mathrm{E}_{\mathrm{MW} \_ \text {post }}$ & & $\begin{array}{l}{[0.035]} \\
-0.060^{*} \\
{[0.034]}\end{array}$ & $\begin{array}{c}{[0.028]} \\
-0.040 \\
{[0.028]}\end{array}$ & $\begin{array}{l}{[0.035]} \\
-0.044^{*} \\
{[0.024]}\end{array}$ & $\begin{array}{c}{[0.003]} \\
-0.007^{*} \\
{[0.004]}\end{array}$ \\
\hline Pseudo-R2 & 0.221 & 0.221 & 0.221 & 0.221 & 0.221 \\
\hline Observations & 1349757 & 1349757 & 1349757 & 1349757 & 1349757 \\
\hline \multicolumn{6}{|c|}{ TREATED: Young - CONTROL: Young Adult } \\
\hline young* $\mathrm{U}_{\mathrm{MW}}$ & $\begin{array}{c}-0.010 \\
{[0.019]}\end{array}$ & $\begin{array}{c}-0.008 \\
{[0.019]}\end{array}$ & $\begin{array}{c}-0.004 \\
{[0.020]}\end{array}$ & $\begin{array}{c}-0.013 \\
{[0.018]}\end{array}$ & $\begin{array}{c}0.015 \\
{[0.021]}\end{array}$ \\
\hline young* $\mathrm{E}_{\mathrm{MW}}$ & $\begin{array}{c}-0.043 * * \\
{[0.018]}\end{array}$ & $\begin{array}{c}-0.074 * * * \\
{[0.018]}\end{array}$ & $\begin{array}{c}-0.043^{* *} \\
{[0.019]}\end{array}$ & $\begin{array}{c}-0.059 * * * \\
{[0.020]}\end{array}$ & $\begin{array}{c}-0.066 * * * \\
{[0.017]}\end{array}$ \\
\hline young* $\mathrm{U}_{\mathrm{MW} \_ \text {pre }}$ & & $\begin{array}{l}-0.010 \\
{[0.019]}\end{array}$ & $\begin{array}{l}-0.010 \\
{[0.012]}\end{array}$ & $\begin{array}{l}-0.007 \\
{[0.019]}\end{array}$ & $\begin{array}{l}-0.001 \\
{[0.001]}\end{array}$ \\
\hline young* $\mathrm{U}_{\mathrm{MW} \_ \text {post }}$ & & $\begin{array}{c}-0.002 \\
{[0.023]}\end{array}$ & $\begin{array}{l}-0.014 \\
{[0.013]}\end{array}$ & $\begin{array}{l}-0.001 \\
{[0.015]}\end{array}$ & $\begin{array}{c}0.000 \\
{[0.002]}\end{array}$ \\
\hline young* $\mathrm{E}_{\mathrm{MW} \_ \text {pre }}$ & & $\begin{array}{c}-0.073 * * * \\
{[0.028]}\end{array}$ & $\begin{array}{c}-0.029 \\
{[0.021]}\end{array}$ & $\begin{array}{c}-0.069 * * * \\
{[0.029]}\end{array}$ & $\begin{array}{c}-0.009 * * * \\
{[0.002]}\end{array}$ \\
\hline young* $\mathrm{E}_{\mathrm{MW} \_ \text {post }}$ & & $\begin{array}{c}-0.111 * * * \\
{[0.022]}\end{array}$ & $\begin{array}{c}-0.081 * * * \\
{[0.019]}\end{array}$ & $\begin{array}{c}-0.094 * * * \\
{[0.017]}\end{array}$ & $\begin{array}{c}-0.014 * * * \\
{[0.003]}\end{array}$ \\
\hline Pseudo-R2 & 0.287 & 0.287 & 0.287 & 0.287 & 0.287 \\
\hline Observations & 1257426 & 1257426 & 1257426 & 1257426 & 1257426 \\
\hline
\end{tabular}

Clustered standard errors are reported in parentheses (cluster: time*region).

* significant at $10 \% ; * *$ significant at $5 \%$;** significant at $1 \%$.

Reading:

The table reports the incremental effect associated to an increase of the minimum wage by $10 \%$, computed for the average treated individual. The values associated to young* $\mathrm{U}_{\mathrm{MW}}$ (_pre and _post), young* $\mathrm{E}_{\mathrm{MW}}$ (_pre and _post), young $* Z_{\mathrm{MW}}$ (_pre and _post) refer respectively to the effect on young employment of the unexpected policy (2004:3), the set of all the expected policies, the set of the Zapatero expected policy (2005-2007).

All equations control for gender, marital status, education, whether the individual attended any courses during the last month, region of residence (18 dummies), time (quarterly) effect and young specific seasonality.

The length of the dynamics (_pre and_post) varies between columns:

(1): no dynamics

(2): pre $=1$ quarter before the policy; post $=1$ quarter after the policy

(3): pre $=2$ quarter before the policy; post $=2$ quarter after the policy

(4): pre $=1$ quarter before the policy; post $=2$ quarter after the policy

(5): $\_$pre $=2$ quarter before the policy; post $=1$ quarter after the policy 
Table 5. Employment ( $U_{M W}$ vs. $\left.Z_{M w}\right)$, Probit regression model.

\begin{tabular}{|c|c|c|c|c|c|}
\hline & (1) & (2) & (3) & (4) & (5) \\
\hline \multicolumn{6}{|c|}{ TREATED: Young - CONTROL: Adult } \\
\hline young* $\mathrm{U}_{\mathrm{MW}}$ & $\begin{array}{l}-0.001 \\
{[0.022]}\end{array}$ & $\begin{array}{l}-0.001 \\
{[0.022]}\end{array}$ & $\begin{array}{c}-0.004 \\
{[0.024]}\end{array}$ & $\begin{array}{c}-0.003 \\
{[0.022]}\end{array}$ & $\begin{array}{l}-0.001 \\
{[0.023]}\end{array}$ \\
\hline young* $\mathrm{Z}_{\mathrm{MW}}$ & $\begin{array}{c}0.007 \\
{[0.018]}\end{array}$ & $\begin{array}{c}0.007 \\
{[0.018]}\end{array}$ & $\begin{array}{c}0.007 \\
{[0.021]}\end{array}$ & $\begin{array}{c}0.006 \\
{[0.021]}\end{array}$ & $\begin{array}{c}0.008 \\
{[0.018]}\end{array}$ \\
\hline young* $\mathrm{U}_{\mathrm{MW} \_ \text {pre }}$ & & $\begin{array}{c}0.010 \\
{[0.022]}\end{array}$ & $\begin{array}{c}0.004 \\
{[0.014]}\end{array}$ & $\begin{array}{c}0.011 \\
{[0.022]}\end{array}$ & $\begin{array}{c}0.000 \\
{[0.002]}\end{array}$ \\
\hline young $* \mathrm{U}_{\mathrm{MW} \_ \text {post }}$ & & $\begin{array}{l}-0.002 \\
{[0.024]}\end{array}$ & $\begin{array}{c}0.002 \\
{[0.016]}\end{array}$ & $\begin{array}{c}0.003 \\
{[0.016]}\end{array}$ & $\begin{array}{c}0.000 \\
{[0.002]}\end{array}$ \\
\hline young* $\mathrm{Z}_{\mathrm{MW} \_ \text {pre }}$ & & $\begin{array}{c}0.004 \\
{[0.022]}\end{array}$ & $\begin{array}{c}0.003 \\
{[0.016]}\end{array}$ & $\begin{array}{c}0.000 \\
{[0.021]}\end{array}$ & $\begin{array}{c}0.000 \\
{[0.002]}\end{array}$ \\
\hline young $* \mathrm{Z}_{\mathrm{MW} \_ \text {post }}$ & & $\begin{array}{l}-0.008 \\
{[0.019]}\end{array}$ & $\begin{array}{c}-0.008 \\
{[0.016]}\end{array}$ & $\begin{array}{l}-0.006 \\
{[0.014]}\end{array}$ & $\begin{array}{l}-0.001 \\
{[0.002]}\end{array}$ \\
\hline $\begin{array}{l}\text { Pseudo-R }{ }^{2} \\
\text { Observations }\end{array}$ & $\begin{array}{c}0.237 \\
2589914\end{array}$ & $\begin{array}{c}0.237 \\
2589914\end{array}$ & $\begin{array}{c}0.237 \\
2589914\end{array}$ & $\begin{array}{c}0.237 \\
2589914\end{array}$ & $\begin{array}{c}0.237 \\
2589914\end{array}$ \\
\hline \multicolumn{6}{|c|}{ TREATED: Young female - CONTROL: Adult female } \\
\hline young* $\mathrm{U}_{\mathrm{MW}}$ & $\begin{array}{l}-0.005 \\
{[0.022]}\end{array}$ & $\begin{array}{l}-0.005 \\
{[0.022]}\end{array}$ & $\begin{array}{c}-0.009 \\
{[0.024]}\end{array}$ & $\begin{array}{l}-0.009 \\
{[0.022]}\end{array}$ & $\begin{array}{c}-0.003 \\
{[0.023]}\end{array}$ \\
\hline young* $Z_{\mathrm{MW}}$ & $\begin{array}{l}-0.006 \\
{[0.017]}\end{array}$ & $\begin{array}{l}-0.006 \\
{[0.017]}\end{array}$ & $\begin{array}{c}-0.001 \\
{[0.020]}\end{array}$ & $\begin{array}{l}-0.002 \\
{[0.019]}\end{array}$ & $\begin{array}{l}-0.007 \\
{[0.018]}\end{array}$ \\
\hline young* $\mathrm{U}_{\mathrm{MW} \_ \text {pre }}$ & & $\begin{array}{c}0.002 \\
{[0.020]}\end{array}$ & $\begin{array}{c}-0.002 \\
{[0.014]}\end{array}$ & $\begin{array}{c}0.003 \\
{[0.020]}\end{array}$ & $\begin{array}{c}0.000 \\
{[0.002]}\end{array}$ \\
\hline young $* \mathrm{U}_{\mathrm{MW} \_ \text {post }}$ & & $\begin{array}{l}-0.020 \\
{[0.020]}\end{array}$ & $\begin{array}{c}-0.008 \\
{[0.014]}\end{array}$ & $\begin{array}{l}-0.006 \\
{[0.015]}\end{array}$ & $\begin{array}{l}-0.002 \\
{[0.002]}\end{array}$ \\
\hline young* $\mathrm{Z}_{\mathrm{MW} \_ \text {pre }}$ & & $\begin{array}{c}0.004 \\
{[0.020]}\end{array}$ & $\begin{array}{c}0.001 \\
{[0.015]}\end{array}$ & $\begin{array}{l}-0.005 \\
{[0.019]}\end{array}$ & $\begin{array}{l}-0.001 \\
{[0.002]}\end{array}$ \\
\hline young $* Z_{\mathrm{MW} \_ \text {post }}$ & & $\begin{array}{l}-0.019 \\
{[0.018]}\end{array}$ & $\begin{array}{l}-0.016 \\
{[0.015]}\end{array}$ & $\begin{array}{c}-0.015 \\
{[0.014]}\end{array}$ & $\begin{array}{l}-0.002 \\
{[0.002]}\end{array}$ \\
\hline $\begin{array}{l}\text { Pseudo-R2 } \\
\text { Observations }\end{array}$ & $\begin{array}{c}0.168 \\
1302474\end{array}$ & $\begin{array}{c}0.168 \\
1302474\end{array}$ & $\begin{array}{c}0.168 \\
1302474\end{array}$ & $\begin{array}{c}0.168 \\
1302474\end{array}$ & $\begin{array}{c}0.168 \\
1302474\end{array}$ \\
\hline \multicolumn{6}{|c|}{ TREATED: Young low education - CONTROL: Adult low education } \\
\hline young* $\mathrm{U}_{\mathrm{MW}}$ & $\begin{array}{c}-0.002 \\
{[0.028]}\end{array}$ & $\begin{array}{l}-0.002 \\
{[0.028]}\end{array}$ & $\begin{array}{c}-0.007 \\
{[0.030]}\end{array}$ & $\begin{array}{l}-0.008 \\
{[0.028]}\end{array}$ & $\begin{array}{c}0.005 \\
{[0.030]}\end{array}$ \\
\hline young* $\mathrm{Z}_{\mathrm{MW}}$ & $\begin{array}{c}0.000 \\
{[0.022]}\end{array}$ & $\begin{array}{c}0.000 \\
{[0.022]}\end{array}$ & $\begin{array}{l}-0.001 \\
{[0.025]}\end{array}$ & $\begin{array}{l}-0.004 \\
{[0.025]}\end{array}$ & $\begin{array}{c}-0.002 \\
{[0.023]}\end{array}$ \\
\hline young* $\mathrm{U}_{\mathrm{MW} \_ \text {pre }}$ & & $\begin{array}{l}-0.004 \\
{[0.027]}\end{array}$ & $\begin{array}{c}-0.007 \\
{[0.018]}\end{array}$ & $\begin{array}{l}-0.002 \\
{[0.027]}\end{array}$ & $\begin{array}{l}-0.001 \\
{[0.002]}\end{array}$ \\
\hline young* $\mathrm{U}_{\mathrm{MW} \_ \text {post }}$ & & $\begin{array}{l}-0.009 \\
{[0.032]}\end{array}$ & $\begin{array}{c}-0.001 \\
{[0.021]}\end{array}$ & $\begin{array}{c}0.006 \\
{[0.021]}\end{array}$ & $\begin{array}{l}-0.001 \\
{[0.003]}\end{array}$ \\
\hline young* $\mathrm{Z}_{\mathrm{MW} \_ \text {pre }}$ & & -0.010 & -0.002 & -0.019 & -0.002 \\
\hline
\end{tabular}




\begin{tabular}{|c|c|c|c|c|c|}
\hline young $* Z_{\mathrm{MW} \_ \text {post }}$ & & $\begin{array}{c}{[0.025]} \\
-0.039 \\
{[0.025]}\end{array}$ & $\begin{array}{c}{[0.020]} \\
-0.029 \\
{[0.020]}\end{array}$ & $\begin{array}{c}{[0.024]} \\
-0.029 \\
{[0.018]}\end{array}$ & $\begin{array}{c}{[0.002]} \\
-0.005 \\
{[0.003]}\end{array}$ \\
\hline Pseudo-R2 & 0.221 & 0.221 & 0.221 & 0.221 & 0.221 \\
\hline Observations & 1349757 & 1349757 & 1349757 & 1349757 & \\
\hline \multicolumn{6}{|c|}{ TREATED: Young - CONTROL: Young Adult } \\
\hline young* $\mathrm{U}_{\mathrm{MW}}$ & $\begin{array}{l}-0.011 \\
{[0.018]}\end{array}$ & $\begin{array}{c}-0.011 \\
{[0.018]}\end{array}$ & $\begin{array}{c}-0.012 \\
{[0.021]}\end{array}$ & $\begin{array}{c}-0.026 \\
{[0.018]}\end{array}$ & $\begin{array}{c}0.016 \\
{[0.021]}\end{array}$ \\
\hline young $* \mathrm{Z}_{\mathrm{MW}}$ & $\begin{array}{c}-0.046^{* * *} * \\
{[0.015]}\end{array}$ & $\begin{array}{c}-0.047 * * * \\
{[0.015]}\end{array}$ & $\begin{array}{c}-0.047 * * * \\
{[0.018]}\end{array}$ & $\begin{array}{c}-0.049 * * * \\
{[0.018]}\end{array}$ & $\begin{array}{c}-0.051 * * * \\
{[0.015]}\end{array}$ \\
\hline young* $\mathrm{U}_{\mathrm{MW} \_ \text {pre }}$ & & $\begin{array}{c}-0.014 \\
{[0.019]}\end{array}$ & $\begin{array}{c}-0.016 \\
{[0.012]}\end{array}$ & $\begin{array}{c}-0.013 \\
{[0.019]}\end{array}$ & $\begin{array}{c}-0.002 \\
{[0.001]}\end{array}$ \\
\hline young* $\mathrm{U}_{\mathrm{MW} \_ \text {post }}$ & & $\begin{array}{c}0.001 \\
{[0.024]}\end{array}$ & $\begin{array}{l}-0.006 \\
{[0.015]}\end{array}$ & $\begin{array}{c}0.004 \\
{[0.016]}\end{array}$ & $\begin{array}{c}0.001 \\
{[0.002]}\end{array}$ \\
\hline young $* \mathrm{Z}_{\mathrm{MW} \_ \text {pre }}$ & & $\begin{array}{c}-0.045^{* *} \\
{[0.022]}\end{array}$ & $\begin{array}{c}-0.024 \\
{[0.015]}\end{array}$ & $\begin{array}{c}-0.047 * * \\
{[0.019]}\end{array}$ & $\begin{array}{c}-0.006 * * * \\
{[0.002]}\end{array}$ \\
\hline young $* Z_{\mathrm{MW} \_ \text {post }}$ & & $\begin{array}{c}-0.071 * * * \\
{[0.017]}\end{array}$ & $\begin{array}{c}-0.056^{* * * *} \\
{[0.014]}\end{array}$ & $\begin{array}{c}-0.067 * * * \\
{[0.013]}\end{array}$ & $\begin{array}{c}-0.009 * * * \\
{[0.002]}\end{array}$ \\
\hline Pseudo-R2 & 0.287 & 0.287 & 0.287 & 0.287 & 0.287 \\
\hline Observations & 1257426 & 1257426 & 1257426 & 1257426 & 1257426 \\
\hline
\end{tabular}

Clustered standard errors are reported in parentheses (cluster: time*region).

* significant at $10 \% ; * *$ significant at $5 \%$; ** significant at $1 \%$.

Reading: see Table 4 
Table 6. Flows out of employment ( $U_{M W}$ vs. $\left.E_{M W}\right)$, Probit regression model.

\begin{tabular}{|c|c|c|c|c|c|}
\hline & (1) & (2) & (3) & (4) & (5) \\
\hline \multicolumn{6}{|c|}{ TREATED: Young - CONTROL: Adult } \\
\hline young* $\mathrm{U}_{\mathrm{MW}}$ & $\begin{array}{c}0.011 \\
{[0.010]}\end{array}$ & $\begin{array}{c}0.010 \\
{[0.010]}\end{array}$ & $\begin{array}{c}-0.001 \\
\lceil 0.010]\end{array}$ & $\begin{array}{c}0.013 \\
{[0.010]}\end{array}$ & $\begin{array}{c}-0.011 \\
{[0.009]}\end{array}$ \\
\hline young* $\mathrm{E}_{\mathrm{MW}}$ & $\begin{array}{c}0.050 * * * \\
{[0.015]}\end{array}$ & $\begin{array}{c}0.071 * * * \\
{[0.017]}\end{array}$ & $\begin{array}{c}0.048 * * * \\
{[0.016]}\end{array}$ & $\begin{array}{c}0.063 * * * \\
{[0.018]}\end{array}$ & $\begin{array}{c}0.056^{* * * *} \\
{[0.016]}\end{array}$ \\
\hline young* $\mathrm{U}_{\mathrm{MW} \_ \text {pre }}$ & & $\begin{array}{c}0.000 \\
{[0.008]}\end{array}$ & $\begin{array}{c}0.002 \\
{[0.007]}\end{array}$ & $\begin{array}{c}0.000 \\
{[0.008]}\end{array}$ & $\begin{array}{c}0.000 \\
{[0.000]}\end{array}$ \\
\hline young $* \mathrm{U}_{\mathrm{MW} \_ \text {post }}$ & & $\begin{array}{c}-0.012 \\
{[0.009]}\end{array}$ & $\begin{array}{c}0.002 \\
{[0.006]}\end{array}$ & $\begin{array}{c}-0.003 \\
{[0.007]}\end{array}$ & $\begin{array}{l}-0.001 * \\
{[0.000]}\end{array}$ \\
\hline young* $\mathrm{E}_{\mathrm{MW} \_ \text {pre }}$ & & $\begin{array}{c}0.083 * * * \\
{[0.026]}\end{array}$ & $\begin{array}{c}0.047 * * * \\
{[0.016]}\end{array}$ & $\begin{array}{c}0.071 * * * \\
{[0.023]}\end{array}$ & $\begin{array}{c}0.003 * * * \\
{[0.001]}\end{array}$ \\
\hline young ${ }^{*} \mathrm{E}_{\mathrm{MW} \_p o s t}$ & & $\begin{array}{c}0.055^{* * * *} \\
{[0.016]}\end{array}$ & $\begin{array}{c}0.040 * * * \\
{[0.013]}\end{array}$ & $\begin{array}{c}0.069 * * * \\
{[0.014]}\end{array}$ & $\begin{array}{c}0.002 * * * \\
{[0.001]}\end{array}$ \\
\hline Pseudo-R ${ }^{2}$ & 0.164 & 0.164 & 0.164 & 0.164 & 0.164 \\
\hline Observations & 956407 & 956407 & 956407 & 956407 & 956407 \\
\hline \multicolumn{6}{|c|}{ TREATED: Young female - CONTROL: Adult female } \\
\hline young* $\mathrm{U}_{\mathrm{MW}}$ & $\begin{array}{c}0.023 \\
{[0.016]}\end{array}$ & $\begin{array}{c}0.023 \\
{[0.016]}\end{array}$ & $\begin{array}{c}0.018 \\
{[0.017]}\end{array}$ & $\begin{array}{c}0.028^{*} \\
{[0.0165]}\end{array}$ & $\begin{array}{c}0.002 \\
{[0.015]}\end{array}$ \\
\hline young* $\mathrm{E}_{\mathrm{MW}}$ & $\begin{array}{l}0.041 * \\
{[0.023]}\end{array}$ & $\begin{array}{l}0.063 * * \\
{[0.025]}\end{array}$ & $\begin{array}{c}0.036 \\
{[0.023]}\end{array}$ & $\begin{array}{l}0.043 * \\
{[0.025]}\end{array}$ & $\begin{array}{l}0.055^{* *} \\
{[0.024]}\end{array}$ \\
\hline young* $\mathrm{U}_{\mathrm{MW} \_p r e}$ & & $\begin{array}{c}0.008 \\
{[0.013]}\end{array}$ & $\begin{array}{c}0.006 \\
{[0.010]}\end{array}$ & $\begin{array}{c}0.007 \\
{[0.013]}\end{array}$ & $\begin{array}{c}0.000 \\
{[0.001]}\end{array}$ \\
\hline young* $\mathrm{U}_{\mathrm{MW} \_ \text {post }}$ & & $\begin{array}{c}0.020 \\
{[0.020]}\end{array}$ & $\begin{array}{c}0.012 \\
{[0.012]}\end{array}$ & $\begin{array}{c}0.010 \\
{[0.013]}\end{array}$ & $\begin{array}{c}0.000 \\
{[0.001]}\end{array}$ \\
\hline young* $\mathrm{E}_{\mathrm{MW} \_ \text {pre }}$ & & $\begin{array}{c}0.026 \\
{[0.034]}\end{array}$ & $\begin{array}{c}0.028 \\
{[0.022]}\end{array}$ & $\begin{array}{c}0.033 \\
{[0.033]}\end{array}$ & $\begin{array}{c}0.003 * * * \\
{[0.001]}\end{array}$ \\
\hline young* $\mathrm{E}_{\mathrm{MW} \_ \text {post }}$ & & $\begin{array}{c}0.075 * * * \\
{[0.027]}\end{array}$ & $\begin{array}{c}0.067 * * * \\
{[0.022]}\end{array}$ & $\begin{array}{c}0.086 * * * \\
{[0.022]}\end{array}$ & $\begin{array}{c}0.003 * * * \\
{[0.001]}\end{array}$ \\
\hline Pseu & 0.160 & 0. & 0 . & 0.1 & 0.160 \\
\hline Observations & 396849 & 396849 & 396849 & 396849 & 396849 \\
\hline \multicolumn{6}{|c|}{ TREATED: Young low education - CONTROL: Adult low education } \\
\hline young* $\mathrm{U}_{\mathrm{MW}}$ & $\begin{array}{c}0.005 \\
{[0.015]}\end{array}$ & $\begin{array}{c}0.004 \\
{[0.015]}\end{array}$ & $\begin{array}{c}-0.006 \\
{[0.015]}\end{array}$ & $\begin{array}{c}0.006 \\
{[0.016]}\end{array}$ & $\begin{array}{c}-0.013 \\
{[0.014]}\end{array}$ \\
\hline young* $\mathrm{E}_{\mathrm{MW}}$ & $\begin{array}{c}0.045^{* *} \\
{[0.020]}\end{array}$ & $\begin{array}{c}0.061 * * * \\
{[0.023]}\end{array}$ & $\begin{array}{c}0.044 * * \\
{[0.021]}\end{array}$ & $\begin{array}{l}0.055 * * \\
{[0.023]}\end{array}$ & $\begin{array}{l}0.050^{* *} \\
{[0.021]}\end{array}$ \\
\hline young* $\mathrm{U}_{\mathrm{MW} \_ \text {pre }}$ & & $\begin{array}{c}-0.004 \\
{[0.015]}\end{array}$ & $\begin{array}{c}0.000 \\
{[0.010]}\end{array}$ & $\begin{array}{c}-0.004 \\
{[0.016]}\end{array}$ & $\begin{array}{c}0.000 \\
{[0.001]}\end{array}$ \\
\hline young* $\mathrm{U}_{\mathrm{MW} \_ \text {post }}$ & & $\begin{array}{c}-0.003 \\
{[0.015]}\end{array}$ & $\begin{array}{c}0.001 \\
{[0.010]}\end{array}$ & $\begin{array}{c}-0.002 \\
{[0.011]}\end{array}$ & $\begin{array}{c}0.000 \\
{[0.001]}\end{array}$ \\
\hline young* $\mathrm{E}_{\mathrm{MW} \_ \text {pre }}$ & & $0.057 * *$ & $0.041 * *$ & $0.056^{* *}$ & $0.003 * * *$ \\
\hline
\end{tabular}




\begin{tabular}{|c|c|c|c|c|c|}
\hline young* $\mathrm{E}_{\mathrm{MW} \_ \text {post }}$ & & $\begin{array}{c}{[0.027]} \\
0.043^{*} \\
{[0.023]}\end{array}$ & $\begin{array}{l}{[0.019]} \\
0.032^{*} \\
{[0.017]}\end{array}$ & $\begin{array}{c}{[0.027]} \\
0.057 * * * \\
{[0.017]}\end{array}$ & $\begin{array}{c}{[0.001]} \\
0.002 * * \\
{[0.001]}\end{array}$ \\
\hline $\begin{array}{l}\text { Pseudo-R2 } \\
\text { Observations }\end{array}$ & $\begin{array}{c}0.146 \\
435374\end{array}$ & $\begin{array}{c}0.146 \\
435374\end{array}$ & $\begin{array}{c}0.146 \\
435374\end{array}$ & $\begin{array}{c}0.146 \\
435374\end{array}$ & $\begin{array}{c}0.146 \\
435374\end{array}$ \\
\hline \multicolumn{6}{|c|}{ TREATED: Young - CONTROL: Young Adult } \\
\hline young* $\mathrm{U}_{\mathrm{MW}}$ & $\begin{array}{c}0.016 \\
{[0.010]}\end{array}$ & $\begin{array}{c}0.015 \\
{[0.010]}\end{array}$ & $\begin{array}{c}0.005 \\
{[0.010]}\end{array}$ & $\begin{array}{l}0.019^{*} \\
{[0.010]}\end{array}$ & $\begin{array}{c}-0.007 \\
{[0.009]}\end{array}$ \\
\hline young $* \mathrm{E}_{\mathrm{MW}}$ & $\begin{array}{c}0.045^{* * *} \\
{[0.016]}\end{array}$ & $\begin{array}{c}0.070 * * * \\
{[0.018]}\end{array}$ & $\begin{array}{c}0.049 * * * \\
{[0.017]}\end{array}$ & $\begin{array}{c}0.065 * * * \\
{[0.019]}\end{array}$ & $\begin{array}{c}0.055^{* * * *} \\
{[0.016]}\end{array}$ \\
\hline young* $\mathrm{U}_{\mathrm{MW} \_ \text {pre }}$ & & $\begin{array}{c}0.009 \\
{[0.008]}\end{array}$ & $\begin{array}{c}0.007 \\
{[0.006]}\end{array}$ & $\begin{array}{c}0.009 \\
{[0.008]}\end{array}$ & $\begin{array}{c}0.001 \\
{[0.000]}\end{array}$ \\
\hline young $* \mathrm{U}_{\mathrm{MW} \_ \text {post }}$ & & $\begin{array}{l}-0.014 \\
{[0.010]}\end{array}$ & $\begin{array}{l}-0.003 \\
{[0.007]}\end{array}$ & $\begin{array}{c}-0.008 \\
{[0.007]}\end{array}$ & $\begin{array}{l}-0.001 * \\
{[0.001]}\end{array}$ \\
\hline young* $\mathrm{E}_{\mathrm{MW} \_ \text {pre }}$ & & $\begin{array}{c}0.076 * * * \\
{[0.027]}\end{array}$ & $\begin{array}{c}0.044 * * * \\
{[0.016]}\end{array}$ & $\begin{array}{c}0.070 * * * \\
{[0.025]}\end{array}$ & $\begin{array}{c}0.005^{* * * *} \\
{[0.001]}\end{array}$ \\
\hline young $* \mathrm{E}_{\mathrm{MW} \_ \text {post }}$ & & $\begin{array}{c}0.067 * * * \\
{[0.020]}\end{array}$ & $\begin{array}{c}0.050 * * * \\
{[0.015]}\end{array}$ & $\begin{array}{c}0.078 * * * \\
{[0.015]}\end{array}$ & $\begin{array}{c}0.003^{* * *} \\
{[0.001]}\end{array}$ \\
\hline Pseudo-R2 & 0.131 & 0.131 & 0.101 & 0.131 & 0.131 \\
\hline Observations & 434228 & 434228 & 434228 & 434228 & 434228 \\
\hline
\end{tabular}

Clustered standard errors are reported in parentheses (cluster: time*region).

* significant at $10 \% ; * *$ significant at $5 \% ; * * *$ significant at $1 \%$.

Reading:

The table reports the incremental effect associated to an increase of the minimum wage by $10 \%$, computed for the average treated individual. The values associated to young* $\mathrm{U}_{\mathrm{MW}}$ (_pre and _post), young ${ }^{*} \mathrm{E}_{\mathrm{MW}}$ (_pre and _post), young* $Z_{\mathrm{MW}}$ (_pre and _post) refer respectively to the effect of the unexpected policy (2004:3), the set of all the expected policies, the set of the Zapatero expected policy (2005-2007).

All equations control for gender, education, contract type, working day lenght, time (quarterly) effect, region (18 dummies), sector (3 dummies), occupation (10 dummies), whether the individual was employed in the public sector and whether she attended any courses during the last month. All the independent variables refer to the initial situation, before the exit from the employment pool.

The length of the dynamics (_pre and _post) varies between columns:

(1): no dynamics

(2): pre $=1$ quarter before the policy; post $=1$ quarter after the policy

(3): pre $=2$ quarter before the policy; post $=2$ quarter after the policy

(4): $\_$pre $=1$ quarter before the policy; post $=2$ quarter after the policy

(5): $\_$pre $=2$ quarter before the policy; _post $=1$ quarter after the policy 
Table 7. Flows out of employment ( $U_{M W}$ vs. $\left.Z_{M W}\right)$, Probit regression model.

\begin{tabular}{|c|c|c|c|c|c|}
\hline & (1) & (2) & (3) & (4) & (5) \\
\hline \multicolumn{6}{|c|}{ TREATED: Young - CONTROL: Adult } \\
\hline young* ${ }^{*}{ }_{M W}$ & $\begin{array}{c}0.012 \\
{[0.010]}\end{array}$ & $\begin{array}{c}0.012 \\
{[0.010]}\end{array}$ & $\begin{array}{c}0.002 \\
{[0.011]}\end{array}$ & $\begin{array}{l}0.024 * * \\
{[0.011]}\end{array}$ & $\begin{array}{c}-0.012 \\
{[0.009]}\end{array}$ \\
\hline young* $\mathrm{Z}_{\mathrm{MW}}$ & $\begin{array}{c}0.050 * * * \\
{[0.011]}\end{array}$ & $\begin{array}{c}0.050 * * * \\
{[0.011]}\end{array}$ & $\begin{array}{c}0.058 * * * \\
{[0.012]}\end{array}$ & $\begin{array}{c}0.057 * * * \\
{[0.012]}\end{array}$ & $\begin{array}{c}0.053 * * * \\
{[0.011]}\end{array}$ \\
\hline young* $\mathrm{U}_{\mathrm{MW} \_ \text {pre }}$ & & $\begin{array}{l}-0.002 \\
{[0.008]}\end{array}$ & $\begin{array}{c}0.006 \\
{[0.007]}\end{array}$ & $\begin{array}{c}0.002 \\
{[0.008]}\end{array}$ & $\begin{array}{c}0.000 \\
{[0.000]}\end{array}$ \\
\hline young $* \mathrm{U}_{\mathrm{MW} \_ \text {post }}$ & & $\begin{array}{c}-0.012 \\
{[0.009]}\end{array}$ & $\begin{array}{c}-0.007 \\
{[0.006]}\end{array}$ & $\begin{array}{c}-0.008 \\
{[0.006]}\end{array}$ & $\begin{array}{c}-0.001 * * \\
{[0.000]}\end{array}$ \\
\hline young* $\mathrm{Z}_{\mathrm{MW} \_ \text {pre }}$ & & $\begin{array}{c}0.043 * * * \\
{[0.015]}\end{array}$ & $\begin{array}{c}0.036 * * * \\
{[0.010]}\end{array}$ & $\begin{array}{l}0.039 * * * \\
{[0.0130]}\end{array}$ & $\begin{array}{c}0.002 * * * \\
{[0.000]}\end{array}$ \\
\hline young $* \mathrm{Z}_{\mathrm{MW} \_p o s t}$ & & $\begin{array}{c}0.027 * * * \\
{[0.011]}\end{array}$ & $\begin{array}{c}0.028 * * * \\
{[0.009]}\end{array}$ & $\begin{array}{c}0.049 * * * \\
{[0.010]}\end{array}$ & $\begin{array}{c}0.001 * * * \\
{[0.000]}\end{array}$ \\
\hline $\begin{array}{l}\text { Pseudo-R }{ }^{2} \\
\text { Observations }\end{array}$ & $\begin{array}{c}0.164 \\
956407\end{array}$ & $\begin{array}{c}0.164 \\
956407\end{array}$ & $\begin{array}{c}0.164 \\
956407\end{array}$ & $\begin{array}{c}0.164 \\
956407\end{array}$ & $\begin{array}{c}0.164 \\
956407\end{array}$ \\
\hline \multicolumn{6}{|c|}{ TREATED: Young female - CONTROL: Adult female } \\
\hline young* $\mathrm{U}_{\mathrm{MW}}$ & $\begin{array}{c}0.025 \\
{[0.016]}\end{array}$ & $\begin{array}{c}0.025 \\
{[0.016]}\end{array}$ & $\begin{array}{c}0.023 \\
{[0.018]}\end{array}$ & $\begin{array}{l}0.040 * * \\
{[0.018]}\end{array}$ & $\begin{array}{c}0.001 \\
{[0.015]}\end{array}$ \\
\hline young* $\mathrm{Z}_{\mathrm{MW}}$ & $\begin{array}{c}0.046 * * * \\
{[0.016]}\end{array}$ & $\begin{array}{c}0.046 * * * \\
{[0.016]}\end{array}$ & $\begin{array}{c}0.047 * * * \\
{[0.017]}\end{array}$ & $\begin{array}{l}0.042 * * \\
{[0.017]}\end{array}$ & $\begin{array}{c}0.049 * * * \\
{[0.016]}\end{array}$ \\
\hline young* $\mathrm{U}_{\mathrm{MW} \_ \text {pre }}$ & & $\begin{array}{c}0.008 \\
{[0.013]}\end{array}$ & $\begin{array}{c}0.011 \\
{[0.011]}\end{array}$ & $\begin{array}{c}0.012 \\
{[0.014]}\end{array}$ & $\begin{array}{c}0.001 \\
{[0.001]}\end{array}$ \\
\hline young* $\mathrm{U}_{\mathrm{MW} \_ \text {post }}$ & & $\begin{array}{c}0.020 \\
{[0.021]}\end{array}$ & $\begin{array}{c}0.004 \\
{[0.012]}\end{array}$ & $\begin{array}{c}0.005 \\
{[0.013]}\end{array}$ & $\begin{array}{c}0.000 \\
{[0.001]}\end{array}$ \\
\hline young* $\mathrm{Z}_{\mathrm{MW} \_ \text {pre }}$ & & $\begin{array}{c}0.010 \\
{[0.021]}\end{array}$ & $\begin{array}{c}0.024 \\
{[0.015]}\end{array}$ & $\begin{array}{c}0.020 \\
{[0.020]}\end{array}$ & $\begin{array}{c}0.002 * * * \\
{[0.001]}\end{array}$ \\
\hline young* $\mathrm{Z}_{\mathrm{MW} \_ \text {post }}$ & & $\begin{array}{l}0.040^{* * *} \\
{[0.018]}\end{array}$ & $\begin{array}{c}0.045^{* * * *} \\
{[0.016]}\end{array}$ & $\begin{array}{c}0.060 * * * \\
{[0.015]}\end{array}$ & $\begin{array}{l}0.002^{* *} \\
{[0.001]}\end{array}$ \\
\hline Pseud & 0.160 & 0 & 0 . & 0.1 & 0.160 \\
\hline Observations & 396849 & 396849 & 396849 & 396849 & 396849 \\
\hline \multicolumn{6}{|c|}{ TREATED: Young low education - CONTROL: Adult low education } \\
\hline young* $\mathrm{U}_{\mathrm{MW}}$ & $\begin{array}{c}0.006 \\
{[0.016]}\end{array}$ & $\begin{array}{c}0.006 \\
{[0.016]}\end{array}$ & $\begin{array}{c}-0.003 \\
{[0.016]}\end{array}$ & $\begin{array}{c}0.014 \\
{[0.017]}\end{array}$ & $\begin{array}{c}-0.013 \\
{[0.014]}\end{array}$ \\
\hline young* $\mathrm{Z}_{\mathrm{MW}}$ & $\begin{array}{c}0.039 * * * \\
{[0.015]}\end{array}$ & $\begin{array}{c}0.039 * * * \\
{[0.015]}\end{array}$ & $\begin{array}{c}0.043 * * \\
{[0.017]}\end{array}$ & $\begin{array}{l}0.042 * * \\
{[0.017]}\end{array}$ & $\begin{array}{c}0.040 * * * \\
{[0.015]}\end{array}$ \\
\hline young* $\mathrm{U}_{\mathrm{MW} \_ \text {pre }}$ & & $\begin{array}{c}-0.006 \\
{[0.015]}\end{array}$ & $\begin{array}{c}0.002 \\
{[0.011]}\end{array}$ & $\begin{array}{c}-0.002 \\
{[0.015]}\end{array}$ & $\begin{array}{c}0.000 \\
{[0.001]}\end{array}$ \\
\hline young* $\mathrm{U}_{\mathrm{MW} \_ \text {post }}$ & & $\begin{array}{l}-0.002 \\
{[0.015]}\end{array}$ & $\begin{array}{l}-0.004 \\
{[0.010]}\end{array}$ & $\begin{array}{c}-0.004 \\
{[0.010]}\end{array}$ & $\begin{array}{c}-0.001 \\
{[0.001]}\end{array}$ \\
\hline young* $\mathrm{Z}_{\mathrm{MW} \_ \text {pre }}$ & & $0.027^{*}$ & $0.028 * *$ & $0.029^{*}$ & $0.002 * * *$ \\
\hline
\end{tabular}




\begin{tabular}{|c|c|c|c|c|c|}
\hline young $* \mathrm{Z}_{\mathrm{MW} \_ \text {post }}$ & & $\begin{array}{c}{[0.016]} \\
0.020 \\
{[0.015]}\end{array}$ & $\begin{array}{l}{[0.013]} \\
0.022^{*} \\
{[0.012]}\end{array}$ & $\begin{array}{c}{[0.016]} \\
0.039 * * * \\
{[0.012]}\end{array}$ & $\begin{array}{c}{[0.001]} \\
0.001 \\
{[0.001]}\end{array}$ \\
\hline $\begin{array}{l}\text { Pseudo-R2 } \\
\text { Observations }\end{array}$ & $\begin{array}{c}0.146 \\
435374\end{array}$ & $\begin{array}{c}0.146 \\
435374\end{array}$ & $\begin{array}{c}0.146 \\
435374\end{array}$ & $\begin{array}{c}0.146 \\
435374\end{array}$ & $\begin{array}{c}0.146 \\
435374\end{array}$ \\
\hline \multicolumn{6}{|c|}{ TREATED: Young - CONTROL: Young Adult } \\
\hline young* $\mathrm{U}_{\mathrm{MW}}$ & $\begin{array}{l}0.018^{*} \\
{[0.011]}\end{array}$ & $\begin{array}{l}0.018^{*} \\
{[0.011]}\end{array}$ & $\begin{array}{c}0.008 \\
{[0.011]}\end{array}$ & $\begin{array}{c}0.030 * * * \\
{[0.011]}\end{array}$ & $\begin{array}{c}-0.008 \\
{[0.009]}\end{array}$ \\
\hline young* $\mathrm{Z}_{\mathrm{MW}}$ & $\begin{array}{c}0.045^{* * *} \\
{[0.011]}\end{array}$ & $\begin{array}{c}0.046 * * * \\
{[0.011]}\end{array}$ & $\begin{array}{c}0.059 * * * \\
{[0.014]}\end{array}$ & $\begin{array}{c}0.056^{* * * *} \\
{[0.014]}\end{array}$ & $\begin{array}{c}0.050 * * * \\
{[0.011]}\end{array}$ \\
\hline young* $\mathrm{U}_{\mathrm{MW} \_ \text {pre }}$ & & $\begin{array}{c}0.008 \\
{[0.008]}\end{array}$ & $\begin{array}{l}0.012 * \\
{[0.006]}\end{array}$ & $\begin{array}{c}0.012 \\
{[0.008]}\end{array}$ & $\begin{array}{l}0.001 * * \\
{[0.000]}\end{array}$ \\
\hline young* $\mathrm{U}_{\mathrm{MW} \_ \text {post }}$ & & $\begin{array}{l}-0.015 \\
{[0.010]}\end{array}$ & $\begin{array}{l}-0.011^{*} \\
{[0.007]}\end{array}$ & $\begin{array}{l}-0.013^{*} \\
{[0.007]}\end{array}$ & $\begin{array}{c}-0.002 * * \\
{[0.001]}\end{array}$ \\
\hline young $* \mathrm{Z}_{\mathrm{MW} \_ \text {pre }}$ & & $\begin{array}{l}0.043^{* *} \\
{[0.017]}\end{array}$ & $\begin{array}{c}0.035 * * * \\
{[0.011]}\end{array}$ & $\begin{array}{c}0.041 * * * \\
{[0.015]}\end{array}$ & $\begin{array}{c}0.003 * * * \\
{[0.001]}\end{array}$ \\
\hline young $* \mathrm{Z}_{\mathrm{MW} \_ \text {post }}$ & & $\begin{array}{c}0.035 * * * \\
{[0.012]}\end{array}$ & $\begin{array}{c}0.032 * * * \\
{[0.010]}\end{array}$ & $\begin{array}{c}0.054 * * * \\
{[0.011]}\end{array}$ & $\begin{array}{c}0.002 * * * \\
{[0.001]}\end{array}$ \\
\hline Pseudo-R2 & 0.131 & 0.131 & 0.131 & 0.131 & 0.131 \\
\hline Observations & 434228 & 434228 & 434228 & 434228 & 434228 \\
\hline
\end{tabular}

Clustered standard errors are reported in parentheses (cluster: time*region).

* significant at $10 \%$;* significant at $5 \%$; ** significant at $1 \%$.

Reading: see Table 6. 
Table 8. Flows out of temporary employment ( $U_{M W}$ vs. $\left.Z_{M w}\right)$, Probit regression model.

\begin{tabular}{|c|c|c|c|c|c|}
\hline & (1) & (2) & (3) & (4) & (5) \\
\hline \multicolumn{6}{|c|}{ TREATED: Young - CONTROL: Adult } \\
\hline young* $\mathrm{U}_{\mathrm{MW}}$ & $\begin{array}{c}0.027 \\
{[0.018]}\end{array}$ & $\begin{array}{c}0.027 \\
{[0.018]}\end{array}$ & $\begin{array}{c}0.011 \\
{[0.018]}\end{array}$ & $\begin{array}{c}0.042 * * \\
{[0.019]}\end{array}$ & $\begin{array}{c}-0.007 \\
{[0.017]}\end{array}$ \\
\hline young* $\mathrm{Z}_{\mathrm{MW}}$ & $\begin{array}{c}0.060 * * * \\
{[0.018]}\end{array}$ & $\begin{array}{c}0.060 * * * \\
{[0.018]}\end{array}$ & $\begin{array}{c}0.074 * * * \\
{[0.021]}\end{array}$ & $\begin{array}{c}0.070 * * * \\
{[0.021]}\end{array}$ & $\begin{array}{c}0.064 * * * \\
{[0.018]}\end{array}$ \\
\hline young* $\mathrm{U}_{\mathrm{MW} \_ \text {pre }}$ & & $\begin{array}{c}-0.006 \\
{[0.015]}\end{array}$ & $\begin{array}{c}0.011 \\
{[0.013]}\end{array}$ & $\begin{array}{c}0.001 \\
{[0.016]}\end{array}$ & $\begin{array}{c}0.001 \\
{[0.001]}\end{array}$ \\
\hline young* $\mathrm{U}_{\mathrm{MW} \_ \text {post }}$ & & $\begin{array}{c}-0.015 \\
{[0.013]}\end{array}$ & $\begin{array}{c}-0.013 \\
{[0.010]}\end{array}$ & $\begin{array}{c}-0.012 \\
{[0.011]}\end{array}$ & $\begin{array}{c}-0.002 * * \\
{[0.001]}\end{array}$ \\
\hline young* $\mathrm{Z}_{\mathrm{MW} \_ \text {pre }}$ & & $\begin{array}{l}0.049 * * \\
{[0.021]}\end{array}$ & $\begin{array}{c}0.049 * * * \\
{[0.015]}\end{array}$ & $\begin{array}{c}0.047 * * * \\
{[0.018]}\end{array}$ & $\begin{array}{c}0.006 * * * \\
{[0.001]}\end{array}$ \\
\hline young $* \mathrm{Z}_{\mathrm{MW} \_ \text {post }}$ & & $\begin{array}{l}0.028^{*} \\
{[0.016]}\end{array}$ & $\begin{array}{l}0.034 * * \\
{[0.014]}\end{array}$ & $\begin{array}{c}0.063 * * * \\
{[0.015]}\end{array}$ & $\begin{array}{c}0.003 * * \\
{[0.001]}\end{array}$ \\
\hline Pseudo-R ${ }^{2}$ & 0.059 & 0.059 & 0.059 & 0.059 & 0.059 \\
\hline Observations & 321076 & 321076 & 321076 & 321076 & 321076 \\
\hline \multicolumn{6}{|c|}{ TREATED: Young female - CONTROL: Adult female } \\
\hline young* $\mathrm{U}_{\mathrm{MW}}$ & $\begin{array}{c}0.036 \\
{[0.029]}\end{array}$ & $\begin{array}{c}0.036 \\
{[0.029]}\end{array}$ & $\begin{array}{c}0.034 \\
{[0.032]}\end{array}$ & $\begin{array}{c}0.055^{*} \\
{[0.031]}\end{array}$ & $\begin{array}{c}0.004 \\
{[0.027]}\end{array}$ \\
\hline young $* Z_{\mathrm{MW}}$ & $\begin{array}{l}0.057 * * \\
{[0.025]}\end{array}$ & $\begin{array}{l}0.057 * * \\
{[0.025]}\end{array}$ & $\begin{array}{l}0.050^{*} \\
{[0.026]}\end{array}$ & $\begin{array}{c}0.041 \\
{[0.025]}\end{array}$ & $\begin{array}{c}0.064 * * \\
{[0.025]}\end{array}$ \\
\hline young* $\mathrm{U}_{\mathrm{MW} \_ \text {pre }}$ & & $\begin{array}{c}0.024 \\
{[0.025]}\end{array}$ & $\begin{array}{c}0.023 \\
{[0.019]}\end{array}$ & $\begin{array}{c}0.031 \\
{[0.026]}\end{array}$ & $\begin{array}{c}0.002 \\
{[0.002]}\end{array}$ \\
\hline young ${ }^{*} \mathrm{U}_{\mathrm{MW} \_ \text {post }}$ & & $\begin{array}{c}0.039 \\
{[0.031]}\end{array}$ & $\begin{array}{c}0.021 \\
{[0.019]}\end{array}$ & $\begin{array}{c}0.025 \\
{[0.020]}\end{array}$ & $\begin{array}{c}0.001 \\
{[0.002]}\end{array}$ \\
\hline young $* Z_{\mathrm{MW} \_p r e}$ & & $\begin{array}{c}0.013 \\
{[0.032]}\end{array}$ & $\begin{array}{c}0.031 \\
{[0.022]}\end{array}$ & $\begin{array}{c}0.021 \\
{[0.029]}\end{array}$ & $\begin{array}{c}0.006 * * * \\
{[0.002]}\end{array}$ \\
\hline young $* \mathrm{Z}_{\mathrm{MW} \_ \text {post }}$ & & $\begin{array}{l}0.049^{*} \\
{[0.025]}\end{array}$ & $\begin{array}{l}0.056^{* *} \\
{[0.022]}\end{array}$ & $\begin{array}{c}0.077 * * * \\
{[0.02]}\end{array}$ & $\begin{array}{c}0.004^{* *} \\
{[0.002]}\end{array}$ \\
\hline Pseudo-R2 & 0.061 & 0.061 & 0.061 & 0.061 & 0.061 \\
\hline Observations & 143464 & 143464 & 143464 & 143464 & 143464 \\
\hline \multicolumn{6}{|c|}{ TREATED: Young low education - CONTROL: Adult low education } \\
\hline young $* \mathrm{U}_{\mathrm{MW}}$ & $\begin{array}{c}0.013 \\
{[0.022]}\end{array}$ & $\begin{array}{c}0.013 \\
{[0.022]}\end{array}$ & $\begin{array}{c}-0.004 \\
{[0.023]}\end{array}$ & $\begin{array}{c}0.022 \\
{[0.024]}\end{array}$ & $\begin{array}{c}-0.015 \\
{[0.021]}\end{array}$ \\
\hline young $* Z_{\mathrm{MW}}$ & $\begin{array}{l}0.054 * * \\
{[0.026]}\end{array}$ & $\begin{array}{c}0.054 * * \\
{[0.026]}\end{array}$ & $\begin{array}{l}0.064 * * \\
{[0.031]}\end{array}$ & $\begin{array}{c}0.062 * * \\
{[0.031]}\end{array}$ & $\begin{array}{l}0.054^{* *} \\
{[0.027]}\end{array}$ \\
\hline young* $\mathrm{U}_{\mathrm{MW} \_ \text {pre }}$ & & $\begin{array}{l}-0.022 \\
{[0.023]}\end{array}$ & $\begin{array}{l}-0.001 \\
{[0.017]}\end{array}$ & $\begin{array}{l}-0.015 \\
{[0.024]}\end{array}$ & $\begin{array}{c}0.000 \\
{[0.002]}\end{array}$ \\
\hline young* $\mathrm{U}_{\mathrm{MW} \_ \text {post }}$ & & $\begin{array}{c}-0.008 \\
{[0.021]}\end{array}$ & $\begin{array}{c}-0.013 \\
{[0.016]}\end{array}$ & $\begin{array}{c}-0.011 \\
{[0.017]}\end{array}$ & $\begin{array}{c}-0.002 \\
{[0.002]}\end{array}$ \\
\hline young* $\mathrm{Z}_{\mathrm{MW} \_ \text {pre }}$ & & 0.035 & $0.044^{* *}$ & $0.038^{*}$ & $0.005 * * *$ \\
\hline
\end{tabular}




\begin{tabular}{|c|c|c|c|c|c|}
\hline young $* Z_{\mathrm{MW}}$ post & & $\begin{array}{c}{[0.022]} \\
0.012 \\
{[0.022]}\end{array}$ & $\begin{array}{c}{[0.019]} \\
0.022 \\
{[0.019]}\end{array}$ & $\begin{array}{c}{[0.022]} \\
0.046 * * * \\
{[0.018]}\end{array}$ & $\begin{array}{c}{[0.001]} \\
0.002 \\
{[0.002]}\end{array}$ \\
\hline $\begin{array}{l}\text { Pseudo-R2 } \\
\text { Observations }\end{array}$ & $\begin{array}{c}0.066 \\
169643\end{array}$ & $\begin{array}{c}0.066 \\
169643\end{array}$ & $\begin{array}{c}0.066 \\
169643\end{array}$ & $\begin{array}{c}0.066 \\
169643\end{array}$ & $\begin{array}{c}0.066 \\
169643\end{array}$ \\
\hline \multicolumn{6}{|c|}{ TREATED: Young - CONTROL: Young Adult } \\
\hline young* $\mathrm{U}_{\mathrm{MW}}$ & $\begin{array}{c}0.022 \\
{[0.018]}\end{array}$ & $\begin{array}{c}0.022 \\
{[0.018]}\end{array}$ & $\begin{array}{c}0.007 \\
{[0.019]}\end{array}$ & $\begin{array}{l}0.039 * * \\
{[0.019]}\end{array}$ & $\begin{array}{c}-0.015 \\
{[0.016]}\end{array}$ \\
\hline young* $\mathrm{Z}_{\mathrm{MW}}$ & $\begin{array}{c}0.057 * * * \\
{[0.016]}\end{array}$ & $\begin{array}{c}0.057 * * * \\
{[0.016]}\end{array}$ & $\begin{array}{c}0.075 * * * \\
{[0.021]}\end{array}$ & $\begin{array}{c}0.070 * * * \\
{[0.022]}\end{array}$ & $\begin{array}{c}0.065 * * * \\
{[0.017]}\end{array}$ \\
\hline young* $\mathrm{U}_{\mathrm{MW} \_ \text {pre }}$ & & $\begin{array}{c}0.012 \\
{[0.013]}\end{array}$ & $\begin{array}{c}0.023 * * \\
{[0.010]}\end{array}$ & {$[0.018$} & $\begin{array}{c}0.002 * * \\
{[0.001]}\end{array}$ \\
\hline young* $\mathrm{U}_{\mathrm{MW} \_ \text {post }}$ & & $\begin{array}{l}-0.015 \\
{[0.015]}\end{array}$ & $\begin{array}{c}-0.014 \\
{[0.010]}\end{array}$ & $\begin{array}{c}-0.016 \\
{[0.011]}\end{array}$ & $\begin{array}{c}-0.002 * * \\
{[0.001]}\end{array}$ \\
\hline young* $Z_{\mathrm{MW} \_ \text {pre }}$ & & $\begin{array}{l}0.060 * * \\
{[0.025]}\end{array}$ & $\begin{array}{c}0.052 * * * \\
{[0.017]}\end{array}$ & $\begin{array}{c}0.062 * * * \\
{[0.02]}\end{array}$ & $\begin{array}{c}0.007 * * * \\
{[0.001]}\end{array}$ \\
\hline young $* Z_{\mathrm{MW} \_ \text {post }}$ & & $\begin{array}{l}0.048^{* *} \\
{[0.019]}\end{array}$ & $\begin{array}{c}0.046 * * * \\
{[0.016]}\end{array}$ & $\begin{array}{c}0.077 * * * \\
{[0.016]}\end{array}$ & $\begin{array}{c}0.004 * * * \\
{[0.001]}\end{array}$ \\
\hline Pseudo-R2 & 0.058 & 0.058 & 0.059 & 0.058 & 0.059 \\
\hline Observations & 209894 & 209894 & 209894 & 209894 & 209894 \\
\hline
\end{tabular}

Clustered standard errors are reported in parentheses (cluster: time*region).

$*$ significant at $10 \%$;* significant at $5 \% ; * * *$ significant at $1 \%$.

Reading: see Table 6. 
Table 9. Flows out of permanent employment ( $U_{M w}$ vs. $\left.Z_{M w}\right)$, Probit regression model.

\begin{tabular}{|c|c|c|c|c|c|}
\hline & (1) & (2) & (3) & (4) & (5) \\
\hline \multicolumn{6}{|c|}{ TREATED: Young - CONTROL: Adult } \\
\hline young $* \mathrm{U}_{\mathrm{MW}}$ & $\begin{array}{c}-0.002 \\
{[0.008]}\end{array}$ & $\begin{array}{l}-0.002 \\
{[0.008]}\end{array}$ & $\begin{array}{l}-0.006 \\
{[0.008]}\end{array}$ & $\begin{array}{c}0.001 \\
{[0.008]}\end{array}$ & $\begin{array}{l}-0.010 \\
{[0.007]}\end{array}$ \\
\hline young* $\mathrm{Z}_{\mathrm{MW}}$ & $\begin{array}{c}0.022 \\
{[0.013]}\end{array}$ & $\begin{array}{c}0.022 \\
{[0.013]}\end{array}$ & $\begin{array}{c}0.019 \\
{[0.015]}\end{array}$ & $\begin{array}{c}0.019 \\
{[0.015]}\end{array}$ & $\begin{array}{c}0.022 \\
{[0.013]}\end{array}$ \\
\hline young* $\mathrm{U}_{\mathrm{MW} \_ \text {pre }}$ & & $\begin{array}{c}0.008 \\
{[0.006]}\end{array}$ & $\begin{array}{c}0.000 \\
{[0.006]}\end{array}$ & $\begin{array}{c}0.009 \\
{[0.006]}\end{array}$ & $\begin{array}{c}0.000 \\
{[0.000]}\end{array}$ \\
\hline young* $\mathrm{U}_{\mathrm{MW} \_ \text {post }}$ & & $\begin{array}{l}-0.001 \\
{[0.008]}\end{array}$ & $\begin{array}{c}0.004 \\
{[0.007]}\end{array}$ & $\begin{array}{c}0.003 \\
{[0.008]}\end{array}$ & $\begin{array}{c}0.000 \\
{[0.000]}\end{array}$ \\
\hline young* $\mathrm{Z}_{\mathrm{MW} \_ \text {pre }}$ & & $\begin{array}{c}0.019 \\
{[0.013]}\end{array}$ & $\begin{array}{c}0.014 \\
{[0.009]}\end{array}$ & $\begin{array}{c}0.015 \\
{[0.012]}\end{array}$ & $\begin{array}{l}0.001 * * \\
{[0.000]}\end{array}$ \\
\hline young $* Z_{\mathrm{MW} \_p o s t}$ & & $\begin{array}{c}0.011 \\
{[0.011]}\end{array}$ & $\begin{array}{c}0.008 \\
{[0.009]}\end{array}$ & $\begin{array}{l}0.018 * * \\
{[0.009]}\end{array}$ & $\begin{array}{c}0.000 \\
{[0.000]}\end{array}$ \\
\hline $\begin{array}{l}\text { Pseudo-R }{ }^{2} \\
\text { Observations }\end{array}$ & $\begin{array}{c}0.066 \\
635331\end{array}$ & $\begin{array}{c}0.066 \\
635331\end{array}$ & $\begin{array}{c}0.066 \\
635331\end{array}$ & $\begin{array}{c}0.066 \\
635331\end{array}$ & $\begin{array}{r}0.066 \\
635331\end{array}$ \\
\hline \multicolumn{6}{|c|}{ TREATED: Young female - CONTROL: Adult female } \\
\hline young* $\mathrm{U}_{\mathrm{MW}}$ & $\begin{array}{c}0.018 \\
{[0.017]}\end{array}$ & $\begin{array}{c}0.018 \\
{[0.017]}\end{array}$ & $\begin{array}{c}0.015 \\
{[0.019]}\end{array}$ & $\begin{array}{c}0.023 \\
{[0.019]}\end{array}$ & $\begin{array}{c}0.010 \\
{[0.017]}\end{array}$ \\
\hline young $* Z_{\mathrm{MW}}$ & $\begin{array}{c}0.012 \\
{[0.019]}\end{array}$ & $\begin{array}{c}0.012 \\
{[0.019]}\end{array}$ & $\begin{array}{c}0.018 \\
{[0.024]}\end{array}$ & $\begin{array}{c}0.020 \\
{[0.024]}\end{array}$ & $\begin{array}{c}0.010 \\
{[0.019]}\end{array}$ \\
\hline young* $\mathrm{U}_{\mathrm{MW} \_ \text {pre }}$ & & $\begin{array}{l}-0.007 \\
{[0.010]}\end{array}$ & $\begin{array}{c}-0.007 \\
{[0.008]}\end{array}$ & $\begin{array}{l}-0.006 \\
{[0.010]}\end{array}$ & $\begin{array}{c}0.000 \\
{[0.000]}\end{array}$ \\
\hline young ${ }^{*} \mathrm{U}_{\mathrm{MW} \_ \text {post }}$ & & $\begin{array}{c}0.008 \\
{[0.019]}\end{array}$ & $\begin{array}{l}-0.010 \\
{[0.011]}\end{array}$ & $\begin{array}{l}-0.010 \\
{[0.011]}\end{array}$ & $\begin{array}{c}0.000 \\
{[0.001]}\end{array}$ \\
\hline young* $\mathrm{Z}_{\mathrm{MW} \_ \text {pre }}$ & & $\begin{array}{l}-0.001 \\
{[0.017]}\end{array}$ & $\begin{array}{c}0.011 \\
{[0.015]}\end{array}$ & $\begin{array}{c}0.012 \\
{[0.019]}\end{array}$ & $\begin{array}{c}0.001 \\
{[0.001]}\end{array}$ \\
\hline young $* \mathrm{Z}_{\mathrm{MW} \_ \text {post }}$ & & $\begin{array}{c}0.013 \\
{[0.018]}\end{array}$ & $\begin{array}{c}0.013 \\
{[0.015]}\end{array}$ & $\begin{array}{c}0.019 \\
{[0.015]}\end{array}$ & $\begin{array}{c}0.001 \\
{[0.001]}\end{array}$ \\
\hline Pseudo-R2 & 0.075 & 0.075 & 0.075 & 0.075 & 0.075 \\
\hline Observations & 253385 & 253385 & 253385 & 253385 & 253385 \\
\hline \multicolumn{6}{|c|}{ TREATED: Young low education - CONTROL: Adult low education } \\
\hline young $* \mathrm{U}_{\mathrm{MW}}$ & $\begin{array}{c}0.010 \\
{[0.013]}\end{array}$ & $\begin{array}{c}0.010 \\
{[0.013]}\end{array}$ & $\begin{array}{c}0.009 \\
{[0.015]}\end{array}$ & $\begin{array}{c}0.015 \\
{[0.014]}\end{array}$ & $\begin{array}{c}0.003 \\
{[0.013]}\end{array}$ \\
\hline young $* Z_{\mathrm{MW}}$ & $\begin{array}{c}0.015 \\
{[0.019]}\end{array}$ & $\begin{array}{c}0.015 \\
{[0.019]}\end{array}$ & $\begin{array}{c}0.012 \\
{[0.020]}\end{array}$ & $\begin{array}{c}0.012 \\
{[0.020]}\end{array}$ & $\begin{array}{c}0.016 \\
{[0.020]}\end{array}$ \\
\hline young* $\mathrm{U}_{\mathrm{MW} \_ \text {pre }}$ & & $\begin{array}{c}0.022 \\
{[0.014]}\end{array}$ & $\begin{array}{c}0.003 \\
{[0.009]}\end{array}$ & $\begin{array}{c}0.021 \\
{[0.014]}\end{array}$ & $\begin{array}{c}0.000 \\
{[0.001]}\end{array}$ \\
\hline young* $\mathrm{U}_{\mathrm{MW} \_ \text {post }}$ & & $\begin{array}{c}0.005 \\
{[0.015]}\end{array}$ & $\begin{array}{c}0.005 \\
{[0.012]}\end{array}$ & $\begin{array}{c}0.004 \\
{[0.013]}\end{array}$ & $\begin{array}{c}0.000 \\
{[0.001]}\end{array}$ \\
\hline young* $\mathrm{Z}_{\mathrm{MW} \_ \text {pre }}$ & & 0.011 & 0.008 & 0.012 & 0.001 \\
\hline
\end{tabular}




\begin{tabular}{|c|c|c|c|c|c|}
\hline young $* \mathrm{Z}_{\mathrm{MW} \_ \text {post }}$ & & $\begin{array}{c}{[0.017]} \\
0.021 \\
{[0.017]}\end{array}$ & $\begin{array}{c}{[0.013]} \\
0.012 \\
{[0.013]}\end{array}$ & $\begin{array}{c}{[0.017]} \\
0.019 \\
{[0.013]}\end{array}$ & $\begin{array}{c}{[0.001]} \\
0.001 \\
{[0.001]}\end{array}$ \\
\hline Pseudo-R2 & 0.059 & 0.059 & 0.059 & 0.059 & 0.059 \\
\hline Observations & 265731 & 265731 & 265731 & 265731 & 265731 \\
\hline \multicolumn{6}{|c|}{ TREATED: Young - CONTROL: Young Adult } \\
\hline young* $\mathrm{U}_{\mathrm{MW}}$ & $\begin{array}{c}0.007 \\
{[0.011]}\end{array}$ & $\begin{array}{c}0.007 \\
{[0.011]}\end{array}$ & $\begin{array}{c}0.003 \\
{[0.012]}\end{array}$ & $\begin{array}{c}0.010 \\
{[0.011]}\end{array}$ & $\begin{array}{c}-0.001 \\
{[0.010]}\end{array}$ \\
\hline young* $\mathrm{Z}_{\mathrm{MW}}$ & $\begin{array}{c}0.018 \\
{[0.013]}\end{array}$ & $\begin{array}{c}0.018 \\
{[0.013]}\end{array}$ & $\begin{array}{c}0.019 \\
{[0.016]}\end{array}$ & $\begin{array}{c}0.019 \\
{[0.016]}\end{array}$ & $\begin{array}{c}0.018 \\
{[0.013]}\end{array}$ \\
\hline young* $\mathrm{U}_{\mathrm{MW} \_ \text {pre }}$ & & $\begin{array}{c}0.008 \\
{[0.008]}\end{array}$ & $\begin{array}{c}-0.001 \\
{[0.006]}\end{array}$ & $\begin{array}{c}0.009 \\
{[0.008]}\end{array}$ & $\begin{array}{c}0.000 \\
{[0.000]}\end{array}$ \\
\hline young* $\mathrm{U}_{\mathrm{MW} \_ \text {post }}$ & & $\begin{array}{c}-0.005 \\
{[0.009]}\end{array}$ & $\begin{array}{c}-0.001 \\
{[0.007]}\end{array}$ & $\begin{array}{c}-0.001 \\
{[0.008]}\end{array}$ & $\begin{array}{c}0.000 \\
{[0.001]}\end{array}$ \\
\hline young* $\mathrm{Z}_{\mathrm{MW} \_ \text {pre }}$ & & $\begin{array}{c}0.013 \\
{[0.015]}\end{array}$ & $\begin{array}{c}0.011 \\
{[0.010]}\end{array}$ & $\begin{array}{c}0.010 \\
{[0.013]}\end{array}$ & $\begin{array}{c}0.001 * \\
{[0.001]}\end{array}$ \\
\hline young $* Z_{\mathrm{MW} \_ \text {post }}$ & & $\begin{array}{c}0.010 \\
{[0.012]}\end{array}$ & $\begin{array}{c}0.008 \\
{[0.010]}\end{array}$ & $\begin{array}{c}0.015 \\
{[0.010]}\end{array}$ & $\begin{array}{c}0.000 \\
{[0.001]}\end{array}$ \\
\hline Pseudo-R2 & 0.049 & 0.049 & 0.050 & 0.050 & 0.050 \\
\hline Observations & 224334 & 224334 & 224334 & 224334 & 224334 \\
\hline
\end{tabular}

Clustered standard errors are reported in parentheses (cluster: time*region).

* significant at $10 \%$;* significant at $5 \%$; *** significant at $1 \%$.

Reading: see Table 6. 
Table 10. Flows into employment ( $\mathrm{U}_{M W}$ vs. $\left.\mathrm{E}_{\mathrm{MW}}\right)$, Probit regression model.

\begin{tabular}{|c|c|c|c|c|c|}
\hline & (1) & $(2)$ & (3) & (4) & (5) \\
\hline \multicolumn{6}{|c|}{ TREATED: Young - CONTROL: Adult } \\
\hline young* $\mathrm{U}_{\mathrm{MW}}$ & $\begin{array}{l}0.040^{*} \\
{[0.024]}\end{array}$ & $\begin{array}{l}0.040 * \\
{[0.024]}\end{array}$ & $\begin{array}{l}0.044 * \\
{[0.026]}\end{array}$ & $\begin{array}{c}0.039 \\
{[0.024]}\end{array}$ & $\begin{array}{c}0.066^{* * *} \\
{[0.025]}\end{array}$ \\
\hline young* $\mathrm{E}_{\mathrm{MW}}$ & $\begin{array}{c}0.022 \\
{[0.032]}\end{array}$ & $\begin{array}{c}0.009 \\
{[0.033]}\end{array}$ & $\begin{array}{c}0.016 \\
{[0.032]}\end{array}$ & $\begin{array}{c}0.014 \\
{[0.033]}\end{array}$ & $\begin{array}{c}0.016 \\
{[0.033]}\end{array}$ \\
\hline young* $\mathrm{U}_{\mathrm{MW} \_ \text {pre }}$ & & $\begin{array}{c}0.000 \\
{[0.016]}\end{array}$ & $\begin{array}{c}-0.004 \\
{[0.017]}\end{array}$ & $\begin{array}{c}0.001 \\
{[0.016]}\end{array}$ & $\begin{array}{c}0.000 \\
{[0.0016]}\end{array}$ \\
\hline young* $\mathrm{U}_{\mathrm{MW} \_ \text {post }}$ & & $\begin{array}{l}0.047^{*} \\
{[0.027]}\end{array}$ & $\begin{array}{c}0.005 \\
{[0.021]}\end{array}$ & $\begin{array}{c}0.005 \\
{[0.022]}\end{array}$ & $\begin{array}{l}0.005 * * \\
{[0.002]}\end{array}$ \\
\hline young* $\mathrm{E}_{\mathrm{MW} \_ \text {pre }}$ & & $\begin{array}{c}-0.052 \\
{[0.037]}\end{array}$ & $\begin{array}{c}-0.014 \\
{[0.030]}\end{array}$ & $\begin{array}{c}-0.013 \\
{[0.041]}\end{array}$ & $\begin{array}{c}-0.006^{* * * *} \\
{[0.002]}\end{array}$ \\
\hline young* $\mathrm{E}_{\mathrm{MW} \_ \text {post }}$ & & $\begin{array}{c}-0.060^{* *} \\
{[0.027]}\end{array}$ & $\begin{array}{c}-0.060^{* * * *} \\
{[0.023]}\end{array}$ & $\begin{array}{c}-0.067 * * * \\
{[0.020]}\end{array}$ & $\begin{array}{c}-0.006^{* *} \\
{[0.003]}\end{array}$ \\
\hline $\begin{array}{l}\text { Pseudo-R }{ }^{2} \\
\text { Observations }\end{array}$ & $\begin{array}{c}0.102 \\
186182\end{array}$ & $\begin{array}{c}0.102 \\
186182\end{array}$ & $\begin{array}{c}0.102 \\
186182\end{array}$ & $\begin{array}{c}0.102 \\
186182\end{array}$ & $\begin{array}{c}0.102 \\
186182\end{array}$ \\
\hline \multicolumn{6}{|c|}{ TREATED: Young female - CONTROL: Adult female } \\
\hline young* $\mathrm{U}_{\mathrm{MW}}$ & $\begin{array}{c}0.039 \\
{[0.024]}\end{array}$ & $\begin{array}{l}0.040 * \\
{[0.024]}\end{array}$ & $\begin{array}{c}0.041 \\
{[0.028]}\end{array}$ & $\begin{array}{c}0.038 \\
{[0.024]}\end{array}$ & $\begin{array}{l}0.068 * * \\
{[0.027]}\end{array}$ \\
\hline young* $\mathrm{E}_{\mathrm{MW}}$ & $\begin{array}{c}0.022 \\
{[0.038]}\end{array}$ & $\begin{array}{l}-0.002 \\
{[0.036]}\end{array}$ & $\begin{array}{c}0.021 \\
{[0.040]}\end{array}$ & $\begin{array}{c}0.012 \\
{[0.041]}\end{array}$ & $\begin{array}{c}0.009 \\
{[0.037]}\end{array}$ \\
\hline young* $\mathrm{U}_{\mathrm{MW} \_ \text {pre }}$ & & $\begin{array}{c}0.005 \\
{[0.023]}\end{array}$ & $\begin{array}{c}0.002 \\
{[0.022]}\end{array}$ & $\begin{array}{c}0.006 \\
{[0.023]}\end{array}$ & $\begin{array}{c}0.000 \\
{[0.002]}\end{array}$ \\
\hline young $* \mathrm{U}_{\mathrm{MW} \_ \text {post }}$ & & $\begin{array}{c}0.052 \\
{[0.047]}\end{array}$ & $\begin{array}{l}-0.005 \\
{[0.027]}\end{array}$ & $\begin{array}{c}0.003 \\
{[0.029]}\end{array}$ & $\begin{array}{c}0.004 \\
{[0.004]}\end{array}$ \\
\hline young* $\mathrm{E}_{\mathrm{Mw}} \_$pre & & $\begin{array}{l}-0.083^{*} \\
{[0.044]}\end{array}$ & $\begin{array}{l}-0.010 \\
{[0.041]}\end{array}$ & $\begin{array}{l}-0.040 \\
{[0.052]}\end{array}$ & $\begin{array}{c}-0.007 * * \\
{[0.003]}\end{array}$ \\
\hline young $* \mathrm{E}_{\mathrm{MW}} \_$post & & $\begin{array}{c}-0.010^{* * * *} \\
{[0.029]}\end{array}$ & $\begin{array}{c}-0.077 * * * \\
{[0.029]}\end{array}$ & $\begin{array}{c}-0.082 * * * \\
{[0.025]}\end{array}$ & $\begin{array}{c}-0.010^{* * * *} \\
{[0.004]}\end{array}$ \\
\hline Pseudo-R2 & 0.111 & 0.111 & 0.111 & 0.111 & 0.111 \\
\hline Observations & 112974 & 112974 & 112974 & 112974 & 112974 \\
\hline \multicolumn{6}{|c|}{ TREATED: Young low education - CONTROL: Adult low education } \\
\hline young* ${ }^{*}{ }_{M W}$ & $\begin{array}{c}0.054 \\
{[0.043]}\end{array}$ & $\begin{array}{c}0.055 \\
{[0.043]}\end{array}$ & $\begin{array}{c}0.075 \\
{[0.047]}\end{array}$ & $\begin{array}{c}0.054 \\
{[0.043]}\end{array}$ & $\begin{array}{c}0.097 * * \\
{[0.047]}\end{array}$ \\
\hline young* $\mathrm{E}_{\mathrm{MW}}$ & $\begin{array}{c}0.001 \\
{[0.040]}\end{array}$ & $\begin{array}{l}-0.023 \\
{[0.039]}\end{array}$ & $\begin{array}{c}-0.008 \\
{[0.041]}\end{array}$ & $\begin{array}{l}-0.020 \\
{[0.043]}\end{array}$ & $\begin{array}{l}-0.011 \\
{[0.041]}\end{array}$ \\
\hline young* $\mathrm{U}_{\mathrm{MW} \_ \text {pre }}$ & & $\begin{array}{l}-0.039^{*} \\
{[0.024]}\end{array}$ & $\begin{array}{c}-0.037 \\
{[0.023]}\end{array}$ & $\begin{array}{l}-0.039^{*} \\
{[0.024]}\end{array}$ & $\begin{array}{l}-0.004 \\
{[0.002]}\end{array}$ \\
\hline young* $\mathrm{U}_{\mathrm{MW} \_ \text {post }}$ & & $\begin{array}{c}0.053 \\
{[0.035]}\end{array}$ & $\begin{array}{c}-0.002 \\
{[0.023]}\end{array}$ & $\begin{array}{c}0.005 \\
{[0.026]}\end{array}$ & $\begin{array}{l}0.005^{* *} \\
{[0.002]}\end{array}$ \\
\hline young* $\mathrm{E}_{\mathrm{MW} \_ \text {pre }}$ & & $-0.099^{*}$ & -0.056 & -0.062 & $-0.010 * * *$ \\
\hline
\end{tabular}




\begin{tabular}{|c|c|c|c|c|c|}
\hline young* $\mathrm{E}_{\mathrm{MW} \_ \text {post }}$ & & $\begin{array}{c}{[0.053]} \\
-0.055 \\
{[0.037]}\end{array}$ & $\begin{array}{c}{[0.038]} \\
-0.054^{*} \\
{[0.033]}\end{array}$ & $\begin{array}{c}{[0.05]} \\
-0.080 * * * \\
{[0.026]}\end{array}$ & $\begin{array}{c}{[0.003]} \\
-0.005 \\
{[0.004]}\end{array}$ \\
\hline Pseudo-R2 & 0.106 & 0.106 & 0.106 & 0.106 & 0.106 \\
\hline Observations & 102096 & 102096 & 102096 & 102096 & 102096 \\
\hline \multicolumn{6}{|c|}{ TREATED: Young - CONTROL: Young Adult } \\
\hline young* $\mathrm{U}_{\mathrm{MW}}$ & $\begin{array}{c}0.035 \\
{[0.023]}\end{array}$ & $\begin{array}{c}0.036 \\
{[0.023]}\end{array}$ & $\begin{array}{l}0.047 * \\
{[0.026]}\end{array}$ & $\begin{array}{c}0.035 \\
{[0.023]}\end{array}$ & $\begin{array}{l}0.066^{* *} \\
{[0.026]}\end{array}$ \\
\hline young* $\mathrm{E}_{\mathrm{MW}}$ & $\begin{array}{c}0.009 \\
{[0.033]}\end{array}$ & $\begin{array}{l}-0.007 \\
{[0.034]}\end{array}$ & $\begin{array}{c}0.014 \\
{[0.033]}\end{array}$ & $\begin{array}{c}0.008 \\
{[0.034]}\end{array}$ & $\begin{array}{c}0.002 \\
{[0.034]}\end{array}$ \\
\hline young* $\mathrm{U}_{\mathrm{MW} \_ \text {pre }}$ & & $\begin{array}{c}0.001 \\
{[0.019]}\end{array}$ & $\begin{array}{c}-0.003 \\
{[0.017]}\end{array}$ & $\begin{array}{c}0.002 \\
{[0.018]}\end{array}$ & $\begin{array}{c}0.000 \\
{[0.002]}\end{array}$ \\
\hline young $* \mathrm{U}_{\mathrm{MW}} \_$post & & $\begin{array}{c}0.023 \\
{[0.024]}\end{array}$ & $\begin{array}{c}-0.014 \\
{[0.021]}\end{array}$ & $\begin{array}{c}-0.011 \\
{[0.022]}\end{array}$ & $\begin{array}{c}0.002 \\
{[0.002]}\end{array}$ \\
\hline young* $\mathrm{E}_{\mathrm{MW} \_ \text {pre }}$ & & $\begin{array}{c}-0.072 * * * \\
{[0.024]}\end{array}$ & $\begin{array}{c}-0.033 \\
{[0.028]}\end{array}$ & $\begin{array}{c}-0.039 \\
{[0.031]}\end{array}$ & $\begin{array}{c}-0.008 * * * \\
{[0.003]}\end{array}$ \\
\hline young $* \mathrm{E}_{\mathrm{MW}} \_$post & & $\begin{array}{c}-0.059 * * \\
{[0.027]}\end{array}$ & $\begin{array}{c}-0.053^{* *} \\
{[0.024]}\end{array}$ & $\begin{array}{c}-0.068 * * * \\
{[0.023]}\end{array}$ & $\begin{array}{c}-0.006^{* *} \\
{[0.003]}\end{array}$ \\
\hline Pseudo-R2 & 0.088 & 0.088 & 0.088 & 0.088 & 0.088 \\
\hline Observations & 113430 & 113430 & 113430 & 113430 & 113430 \\
\hline
\end{tabular}

Clustered standard errors are reported in parentheses (cluster: time*region).

* significant at $10 \% ; * *$ significant at $5 \% ; * * *$ significant at $1 \%$.

Reading:

The table reports the incremental effect associated to an increase of the minimum wage by $10 \%$, computed for the average treated individual. The values associated to young* $\mathrm{U}_{\mathrm{MW}}$ (_pre and _post), young ${ }^{*} \mathrm{E}_{\mathrm{MW}}$ (_pre and _post), young* $Z_{\mathrm{MW}}$ (_pre and _post) refer respectively to the effect of the unexpected policy (2004:3), the set of all the expected policies, the set of the Zapatero expected policy (2005-2007).

All equations control for gender, education, time (quarterly) effect, region (18 dummies), whether the individual is looking for the first job or last sector (3 dummies) and occupation (10 dummies) where she was employed, whether she was in the public sector, attended any courses during the last month, adopted active methods to search for a job, whether she was waiting to start a new job. All the independent variables refer to the initial situation, before the exit from the nonemployment pool.

The length of the dynamics (_pre and _post) varies between columns:

(1): no dynamics

(2): $\_$pre $=1$ quarter before the policy; $\_$post $=1$ quarter after the policy

(3): $\_$pre $=2$ quarter before the policy; $\_$post $=2$ quarter after the policy

(4): $\_$pre $=1$ quarter before the policy; _ post $=2$ quarter after the policy

(5): pre $=2$ quarter before the policy; $\_$post $=1$ quarter after the policy 
Table 11. Flows into employment ( $U_{M W}$ vs. $\left.Z_{M w}\right)$, Probit regression model.

\begin{tabular}{|c|c|c|c|c|c|}
\hline & (1) & (2) & (3) & (4) & (5) \\
\hline \multicolumn{6}{|c|}{ TREATED: Young - CONTROL: Adult } \\
\hline young* $\mathrm{U}_{\mathrm{MW}}$ & $\begin{array}{l}0.041^{*} \\
{[0.024]}\end{array}$ & $\begin{array}{l}0.041 * \\
{[0.024]}\end{array}$ & $\begin{array}{c}0.037 \\
{[0.027]}\end{array}$ & $\begin{array}{c}0.031 \\
{[0.024]}\end{array}$ & $\begin{array}{c}0.067 * * * \\
{[0.026]}\end{array}$ \\
\hline young* $\mathrm{Z}_{\mathrm{MW}}$ & $\begin{array}{c}0.010 \\
{[0.028]}\end{array}$ & $\begin{array}{c}0.010 \\
{[0.028]}\end{array}$ & $\begin{array}{c}0.005 \\
{[0.027]}\end{array}$ & $\begin{array}{c}0.007 \\
{[0.027]}\end{array}$ & $\begin{array}{c}0.008 \\
{[0.027]}\end{array}$ \\
\hline young* $\mathrm{U}_{\mathrm{MW} \_ \text {pre }}$ & & $\begin{array}{l}-0.008 \\
{[0.016]}\end{array}$ & $\begin{array}{c}-0.007 \\
{[0.016]}\end{array}$ & $\begin{array}{c}-0.009 \\
{[0.016]}\end{array}$ & $\begin{array}{l}-0.001 \\
{[0.002]}\end{array}$ \\
\hline young $* \mathrm{U}_{\mathrm{MW}}$ post & & $\begin{array}{l}0.047^{*} \\
{[0.027]}\end{array}$ & $\begin{array}{c}0.005 \\
{[0.021]}\end{array}$ & $\begin{array}{c}0.005 \\
{[0.022]}\end{array}$ & $\begin{array}{l}0.005^{* *} \\
{[0.002]}\end{array}$ \\
\hline young $* \mathrm{Z}_{\mathrm{MW} \_ \text {pre }}$ & & $\begin{array}{l}-0.035 \\
{[0.024]}\end{array}$ & $\begin{array}{l}-0.008 \\
{[0.020]}\end{array}$ & $\begin{array}{c}-0.008 \\
{[0.027]}\end{array}$ & $\begin{array}{c}-0.004 * * * \\
{[0.002]}\end{array}$ \\
\hline young $* Z_{\mathrm{MW} \_p o s t}$ & & $\begin{array}{c}-0.042 * * \\
{[0.019]}\end{array}$ & $\begin{array}{c}-0.042 * * \\
{[0.017]}\end{array}$ & $\begin{array}{c}-0.046^{* * *} \\
{[0.014]}\end{array}$ & $\begin{array}{c}-0.004 * * \\
{[0.002]}\end{array}$ \\
\hline $\begin{array}{l}\text { Pseudo-R }{ }^{2} \\
\text { Observations }\end{array}$ & $\begin{array}{c}0.102 \\
186182\end{array}$ & $\begin{array}{c}0.102 \\
186182\end{array}$ & $\begin{array}{c}0.102 \\
186182\end{array}$ & $\begin{array}{c}0.102 \\
186182\end{array}$ & $\begin{array}{c}0.102 \\
186182\end{array}$ \\
\hline \multicolumn{6}{|c|}{ TREATED: Young female - CONTROL: Adult female } \\
\hline young $* \mathrm{U}_{\mathrm{MW}}$ & $\begin{array}{l}0.040^{*} \\
{[0.024]}\end{array}$ & $\begin{array}{l}0.040^{*} \\
{[0.024]}\end{array}$ & $\begin{array}{c}0.030 \\
{[0.030]}\end{array}$ & $\begin{array}{c}0.028 \\
{[0.025]}\end{array}$ & $\begin{array}{l}0.070 * * \\
{[0.027]}\end{array}$ \\
\hline young $* \mathrm{Z}_{\mathrm{MW}}$ & $\begin{array}{c}0.012 \\
{[0.031]}\end{array}$ & $\begin{array}{c}0.012 \\
{[0.031]}\end{array}$ & $\begin{array}{c}0.016 \\
{[0.034]}\end{array}$ & $\begin{array}{c}0.009 \\
{[0.034]}\end{array}$ & $\begin{array}{c}0.010 \\
{[0.030]}\end{array}$ \\
\hline young* $\mathrm{U}_{\mathrm{MW} \_ \text {pre }}$ & & $\begin{array}{l}-0.008 \\
{[0.022]}\end{array}$ & $\begin{array}{c}-0.003 \\
{[0.021]}\end{array}$ & $\begin{array}{l}-0.005 \\
{[0.022]}\end{array}$ & $\begin{array}{c}0.000 \\
{[0.002]}\end{array}$ \\
\hline young* $\mathrm{U}_{\mathrm{MW} \_ \text {post }}$ & & $\begin{array}{c}0.058 \\
{[0.048]}\end{array}$ & $\begin{array}{c}-0.008 \\
{[0.028]}\end{array}$ & $\begin{array}{c}0.003 \\
{[0.030]}\end{array}$ & $\begin{array}{c}0.004 \\
{[0.004]}\end{array}$ \\
\hline young* $\mathrm{Z}_{\mathrm{MW} \_ \text {pre }}$ & & $\begin{array}{c}-0.062^{* *} \\
{[0.030]}\end{array}$ & $\begin{array}{c}-0.004 \\
{[0.028]}\end{array}$ & $\begin{array}{c}-0.030 \\
{[0.034]}\end{array}$ & $\begin{array}{c}-0.005^{* *} \\
{[0.002]}\end{array}$ \\
\hline young $* \mathrm{Z}_{\mathrm{MW} \_ \text {post }}$ & & $\begin{array}{c}-0.071 * * * \\
{[0.022]}\end{array}$ & $\begin{array}{c}-0.055^{* *} \\
{[0.022]}\end{array}$ & $\begin{array}{c}-0.057 * * * \\
{[0.018]}\end{array}$ & $\begin{array}{c}-0.007 * * * \\
{[0.002]}\end{array}$ \\
\hline Pseudo-R2 & 0.111 & 0.111 & 0.111 & 0.111 & 0.111 \\
\hline Observations & 112974 & 112974 & 112974 & 112974 & 112974 \\
\hline \multicolumn{6}{|c|}{ TREATED: Young low education - CONTROL: Adult low education } \\
\hline young* $\mathrm{U}_{\mathrm{MW}}$ & $\begin{array}{c}0.054 \\
{[0.043]}\end{array}$ & $\begin{array}{c}0.054 \\
{[0.043]}\end{array}$ & $\begin{array}{c}0.069 \\
{[0.048]}\end{array}$ & $\begin{array}{c}0.043 \\
{[0.043]}\end{array}$ & $\begin{array}{c}0.097 * * \\
{[0.047]}\end{array}$ \\
\hline young $* Z_{\mathrm{MW}}$ & $\begin{array}{l}-0.009 \\
{[0.034]}\end{array}$ & $\begin{array}{l}-0.009 \\
{[0.034]}\end{array}$ & $\begin{array}{c}-0.022 \\
{[0.035]}\end{array}$ & $\begin{array}{c}-0.010 \\
{[0.038]}\end{array}$ & $\begin{array}{l}-0.020 \\
{[0.032]}\end{array}$ \\
\hline young* $\mathrm{U}_{\mathrm{MW} \_ \text {pre }}$ & & $\begin{array}{l}-0.041^{*} \\
{[0.024]}\end{array}$ & $\begin{array}{l}-0.041^{*} \\
{[0.023]}\end{array}$ & $\begin{array}{c}-0.046^{* *} \\
{[0.023]}\end{array}$ & $\begin{array}{l}-0.004^{*} \\
{[0.002]}\end{array}$ \\
\hline young $* \mathrm{U}_{\mathrm{MW} \_ \text {post }}$ & & $\begin{array}{c}0.048 \\
{[0.036]}\end{array}$ & $\begin{array}{c}0.004 \\
{[0.025]}\end{array}$ & $\begin{array}{c}0.001 \\
{[0.027]}\end{array}$ & $\begin{array}{l}0.005^{* *} \\
{[0.002]}\end{array}$ \\
\hline young* $\mathrm{Z}_{\mathrm{MW} \_ \text {pre }}$ & & -0.058 & -0.038 & -0.030 & $-0.007 * * *$ \\
\hline
\end{tabular}




\begin{tabular}{|c|c|c|c|c|c|}
\hline young $* Z_{\mathrm{MW} \_ \text {post }}$ & & $\begin{array}{l}{[0.039]} \\
-0.030 \\
{[0.028]}\end{array}$ & $\begin{array}{c}{[0.026]} \\
-0.035 \\
{[0.024]}\end{array}$ & $\begin{array}{c}{[0.036]} \\
-0.054 * * * \\
{[0.020]}\end{array}$ & $\begin{array}{l}{[0.002]} \\
-0.003 \\
{[0.003]}\end{array}$ \\
\hline $\begin{array}{l}\text { Pseudo-R2 } \\
\text { Observations }\end{array}$ & $\begin{array}{c}0.106 \\
102096\end{array}$ & $\begin{array}{c}0.106 \\
102096\end{array}$ & $\begin{array}{c}0.106 \\
102096\end{array}$ & $\begin{array}{c}0.106 \\
102096\end{array}$ & $\begin{array}{c}0.106 \\
102096\end{array}$ \\
\hline \multicolumn{6}{|c|}{ TREATED: Young - CONTROL: Young Adult } \\
\hline young $* \mathrm{U}_{\mathrm{MW}}$ & $\begin{array}{c}0.036 \\
{[0.023]}\end{array}$ & $\begin{array}{c}0.036 \\
{[0.023]}\end{array}$ & $\begin{array}{c}0.041 \\
{[0.027]}\end{array}$ & $\begin{array}{c}0.027 \\
{[0.023]}\end{array}$ & $\begin{array}{l}0.067 * * \\
{[0.027]}\end{array}$ \\
\hline young $* \mathrm{Z}_{\mathrm{MW}}$ & $\begin{array}{c}-0.005 \\
{[0.028]}\end{array}$ & $\begin{array}{l}-0.005 \\
{[0.028]}\end{array}$ & $\begin{array}{c}0.001 \\
{[0.028]}\end{array}$ & $\begin{array}{c}0.002 \\
{[0.028]}\end{array}$ & $\begin{array}{c}-0.006 \\
{[0.028]}\end{array}$ \\
\hline young* $\mathrm{U}_{\mathrm{MW} \_ \text {pre }}$ & & $\begin{array}{l}-0.005 \\
{[0.018]}\end{array}$ & $\begin{array}{c}-0.006 \\
{[0.016]}\end{array}$ & $\begin{array}{c}-0.007 \\
{[0.018]}\end{array}$ & $\begin{array}{c}-0.001 \\
{[0.002]}\end{array}$ \\
\hline young* $U_{M W} \_$post & & $\begin{array}{c}0.025 \\
{[0.024]}\end{array}$ & $\begin{array}{l}-0.012 \\
{[0.021]}\end{array}$ & $\begin{array}{l}-0.010 \\
{[0.022]}\end{array}$ & $\begin{array}{c}0.003 \\
{[0.002]}\end{array}$ \\
\hline young* $\mathrm{Z}_{\mathrm{MW} \_ \text {pre }}$ & & $\begin{array}{c}-0.049 * * * \\
{[0.016]}\end{array}$ & $\begin{array}{c}-0.022 \\
{[0.019]}\end{array}$ & $\begin{array}{l}-0.027 \\
{[0.021]}\end{array}$ & $\begin{array}{c}-0.005 * * * \\
{[0.002]}\end{array}$ \\
\hline young $* Z_{\mathrm{MW} \_ \text {post }}$ & & $\begin{array}{c}-0.040^{* *} \\
{[0.019]}\end{array}$ & $\begin{array}{c}-0.037 * * \\
{[0.017]}\end{array}$ & $\begin{array}{c}-0.048^{* * * *} \\
{[0.017]}\end{array}$ & $\begin{array}{c}-0.004 * * \\
{[0.002]}\end{array}$ \\
\hline Pseudo-R2 & 0.088 & 0.088 & 0.088 & 0.088 & 0.088 \\
\hline Observations & 113430 & 113430 & 113430 & 113430 & 113430 \\
\hline
\end{tabular}

Clustered standard errors are reported in parentheses (cluster: time*region).

* significant at $10 \% ; * *$ significant at $5 \%$; ** significant at $1 \%$.

Reading: see Table 10. 


\section{A The model}

\section{A.1 Equilibrium conditions in state 2:}

Let's recall the firm's value function.

Job value function:

$$
r J_{2}(x)=x-w_{2}+\lambda \int_{d_{2}}^{x^{u}}\left[J_{2}(s)-J_{2}(x)\right] d H(s)-\lambda H\left(d_{2}\right)\left[F+J_{2}(x)\right]
$$

Vacancy value function:

$$
r V_{2}=-k+q_{2} \int_{a_{2}}^{x^{u}}\left[J_{2}(s)-V_{2}\right] d H(s)
$$

JOB DESTRUCTION:

The job destruction condition is

$$
J_{2}\left(d_{2}\right)=-F
$$

Subtracting 29 from 27, we get:

$$
(r+\lambda)\left[J_{2}(x)-J_{2}\left(d_{2}\right)\right]=x-d_{2}
$$

and

$$
J_{2}(x)=\frac{x-d_{2}}{r+\lambda}-F
$$

so that we can simplify the integral in 27 , and rewrite the value function as:

$$
(r+\lambda) J_{2}(x)=x-w_{2}+\frac{\lambda}{r+\lambda} \int_{d_{2}}^{x^{u}}\left(s-d_{2}\right) d H(s)-\lambda F
$$

Valuating the value function in $d_{2}$, we get the job destruction equation:

$$
d_{2}=w_{2}-\frac{\lambda}{r+\lambda} \int_{d_{2}}^{x^{u}}\left(s-d_{2}\right) d H(s)-r F
$$

\section{MATCH FORMATION:}

The job formation condition is

$$
J_{2}\left(a_{2}\right)=0
$$

Substituting condition 34 into equation 32 we get:

$$
a_{2}=w_{2}-\frac{\lambda}{r+\lambda} \int_{d_{2}}^{x^{u}}\left(s-d_{2}\right) d H(s)+\lambda F=d_{2}+(r+\lambda) F
$$

JOB CREATION:

The free entry condition is

$$
V=0
$$


Substituting the free entry condition into the value function of a vacancy, we get:

$$
\int_{a_{2}}^{x^{u}} J_{2}(s) d H(s)=\frac{k}{q_{2}}
$$

Furthermore, using the match formation condition and the linearity property of the job value function, we can write:

$$
J_{2}(x)=\frac{x-a_{2}}{r+\lambda}
$$

Substituting 38 into 37, we get:

$$
\frac{1}{r+\lambda} \int_{a_{2}}^{x^{u}}\left(s-a_{2}\right) d H(s)=\frac{k}{q_{2}}
$$

\section{A.2 Equilibrium conditions in state 1:}

Job value function:

$$
\begin{gathered}
r J_{1}(x)= \\
\begin{cases}x-w_{1}+\lambda \int_{d_{1}^{u}}^{x^{u}}\left[J_{1}(s)-J_{1}(x)\right] d H(s)-\left[\lambda H\left(d_{1}\right)+\phi_{1}\right]\left[F+J_{1}(x)\right] & \text { if } x<d_{2} \\
x-w_{1}+\lambda \int_{d_{1}}^{x_{1}}\left[J_{1}(s)-J_{1}(x)\right] d H(s)-\lambda H\left(d_{1}\right)\left[F+J_{1}(x)\right]+\phi_{1}\left[J_{2}(x)-J_{1}(x)\right] & \text { if } x \geq d_{2}\end{cases}
\end{gathered}
$$

$J_{1}(x)$ is composed by two linear segments with slope $\frac{1}{r+\lambda+\phi}$, if $x<d_{2}$, and $\frac{1}{r+\lambda}$, elsewhere. Note that the distance between $J_{2}(x)$ and the second segment of $J_{1}(x)$ is equal to $\frac{d_{2}-d_{1}}{r+\lambda+\phi}$. Therefore 3 cases are possible:

A. $d_{1}<d_{2}$ and $J_{1}\left(d_{2}\right)>0$, i.e. the second segment $J_{1}(x)$ lies above $J_{2}(x)$ and does not intersect the horizontal axis;

B. $d_{1}<d_{2}$ and $-F<J_{1}\left(d_{2}\right)<0$, i.e. the second segment $J_{1}(x)$ lies above $J_{2}(x)$ and intersects the horizontal axis;

C. $d_{1}>d_{2}$, i.e. the second segment $J_{1}(x)$ lies below $J_{2}(x)$.

We can prove that the third case is impossible.

Let's analyze the first two cases. After some computation, assuming $d_{1}<d_{2}$, we can rewrite the second segment of $J_{1}(x)$ as:

$$
\begin{aligned}
(r+\lambda) J_{1}(x)= & x-w_{1}+\phi\left[J_{2}(x)-J_{1}(x)\right]-\lambda F+\lambda\left[1-H\left(d_{2}\right)\right] \frac{d_{2}-d_{1}}{r+\lambda+\phi} \\
& +\lambda\left[\frac{1}{r+\lambda+\phi} \int_{d_{1}}^{d_{2}}\left(s-d_{1}\right) d H(s)+\frac{1}{r+\lambda} \int_{d_{2}}^{x^{u}}\left(s-d_{2}\right) d H(s)\right]
\end{aligned}
$$

CASE A:

Using condition 29 , we have that $J_{1}\left(d_{2}\right)>0$ is equivalent to:

$$
C=(r+\lambda+\phi)\left[J_{1}\left(d_{2}\right)-J_{2}\left(d_{2}\right)\right]>(r+\lambda+\phi) F
$$


Let's compute $C$ using equations 41 and 32 :

$C=w_{2}-w_{1}+\frac{\lambda}{r+\lambda+\phi} \int_{d_{1}}^{d_{2}}\left(s-d_{1}\right) d H(s)+\frac{\lambda}{r+\lambda}\left[\int_{d_{1}}^{x^{u}}\left(s-d_{1}\right) d H(s)-\int_{d_{2}}^{x^{u}}\left(s-d_{2}\right) d H(s)\right]$

We know that the second segment of $J_{1}(x)$ is parallel to $J_{2}(x)$ at distance $\frac{d_{2}-d_{1}}{r+\lambda+\phi}$, therefore it has also to be true that

$$
C=d_{1}-d_{2}
$$

JOB DESTRUCTION:

When $J_{1}\left(d_{2}\right)>0$, the job destruction threshold has to belong to the first segment. Therefore, imposing the job destruction condition, we have:

$$
d_{1}=w_{1}-\lambda\left[\begin{array}{c}
\frac{1}{r+\lambda+\phi} \int_{d_{1}}^{d_{2}}\left(s-d_{1}\right) d H(s) \\
+\left[1-H\left(d_{2}\right)\right] \frac{d_{2}-d_{1}}{r+\lambda+\phi}
\end{array}\right]-\frac{\lambda}{r+\lambda} \int_{d_{2}}^{x^{u}}\left(s-d_{2}\right) d H(s)-r F
$$

We can easily check that $d_{1}<d_{2}$. Furthermore, substituting 33 into 45 condition 44 is verified.

MATCH FORMATION:

Also the hiring standard has to belong to the first segment:

$$
\begin{aligned}
a_{1} & =w_{1}+(\lambda+\phi) F-\lambda\left[\begin{array}{c}
\frac{1}{r+\lambda+\phi} \int_{d_{1}}^{d_{2}}\left(s-d_{1}\right) d H(s) \\
+\left[1-H\left(d_{2}\right)\right] \frac{d_{2}-d_{1}}{r+\lambda+\phi}
\end{array}\right]-\frac{\lambda}{r+\lambda} \int_{d_{2}}^{x^{u}}\left(s-d_{2}\right) d H\left(s \chi_{1} 46\right) \\
& =d_{1}+(r+\lambda+\phi) F
\end{aligned}
$$

JOB CREATION:

Following the same steps explained in the derivation of 39, we can derive:

$$
\left[\begin{array}{c}
\frac{1}{r+\lambda+\phi} \int_{a_{1}}^{d_{2}}\left(s-a_{1}\right) d H(s) \\
+\frac{1}{r+\lambda} \int_{d_{2}}^{x^{u}}\left(s-d_{2}\right) d H(s)+\left[1-H\left(d_{2}\right)\right]\left(\frac{d_{2}-d_{1}}{r+\lambda+\phi}-F\right)
\end{array}\right]=\frac{k}{q_{1}}
$$

\section{CASE B:}

$-F<J_{1}\left(d_{2}\right)<0$ is equivalent to:

$$
C<(r+\lambda+\phi) F
$$

\section{JOB DESTRUCTION:}

When $-F<J_{1}\left(d_{2}\right)<0$ the job destruction threshold has to belong to the first segment. Therefore we can use the result from case A:

$$
d_{1}=w_{1}-\lambda\left[\begin{array}{c}
\frac{1}{r+\lambda+\phi} \int_{d_{1}}^{d_{2}}\left(s-d_{1}\right) d H(s) \\
+\left[1-H\left(d_{2}\right)\right] \frac{d_{2}-d_{1}}{r+\lambda+\phi}
\end{array}\right]-\frac{\lambda}{r+\lambda} \int_{d_{2}}^{x^{u}}\left(s-d_{2}\right) d H(s)-r F
$$

As for case A, condition 44 is verified.

MATCH FORMATION: 
Now the hiring standard has to belong to the second segment:

$$
\begin{aligned}
a_{1} & =w_{1}-\lambda\left[\begin{array}{c}
\frac{1}{r+\lambda+\phi} \int_{d_{1}}^{d_{2}}\left(s-d_{1}\right) d H(s) \\
+\left[1-H\left(d_{2}\right)\right] \frac{d_{2}-d_{1}}{r+\lambda+\phi}
\end{array}\right]-\frac{\lambda}{r+\lambda} \int_{d_{2}}^{x^{u}}\left(s-d_{2}\right) d H(s)+\lambda F+\phi \frac{\left.d_{2}-d_{1}\right)}{r+\lambda+\phi} \\
& =d_{1}+(r+\lambda) F+\phi \frac{d_{2}-d_{1}}{r+\lambda+\phi}
\end{aligned}
$$

JOB CREATION:

Following the same steps explained in the derivation of 39, we can derive:

$$
\frac{1}{r+\lambda} \int_{a_{1}}^{x^{u}}\left(s-a_{1}\right) d H(s)=\frac{k}{q_{1}}
$$

\section{A.3 Impossibility of case C}

Suppose that $d_{1}>d_{2}$. Then, we can rewrite the second segment of $J_{1}(x)$ as:

$$
(r+\lambda) J_{1}(x)=x-w_{1}-\phi\left[J_{1}(x)-J_{2}(x)\right]+\frac{\lambda}{r+\lambda} \int_{d_{1}}^{x^{u}}\left(s-d_{1}\right) d H(s)-\lambda F
$$

In this case:

$[r+\lambda+\phi]\left[J_{1}(x)-J_{2}(x)\right]=w_{2}-w_{1}+\frac{\lambda}{r+\lambda}\left[\int_{d_{1}}^{x^{u}}\left(s-d_{1}\right) d H(s)-\int_{d_{2}}^{x^{u}}\left(s-d_{2}\right) d H(s)\right]=A$

It has also to be true that $[r+\lambda+\phi]\left[J_{1}(x)-J_{2}(x)\right]=d_{1}-d_{2}$, that is:

$$
w_{2}-w_{1}+\frac{\lambda}{r+\lambda}\left[\int_{d_{1}}^{x^{u}}\left(s-d_{1}\right) d H(s)-\int_{d_{2}}^{x^{u}}\left(s-d_{2}\right) d H(s)\right]=d_{1}-d_{2}
$$

\section{JOB DESTRUCTION:}

When $J_{1}\left(d_{2}\right)<0$, the job destruction threshold has to belong to the first segment. Therefore:

$$
d_{1}=w_{1}-\frac{\lambda}{r+\lambda} \int_{d_{1}}^{x^{u}}\left(s-d_{1}\right) d H(s)-r F+\phi \frac{d_{2}-d_{1}}{r+\lambda+\phi}
$$

Note that $d_{1}>d_{2}$

If we substitute $\left(\mathrm{JD}_{1}^{C}\right)$ and $\left(\mathrm{JD}_{2}\right)$ in condition $(35)$, we get:

$$
\begin{aligned}
d_{1}-d_{2} & =w_{2}-w_{1}+\frac{\lambda}{r+\lambda}\left[\int_{d_{1}}^{x^{u}}\left(s-d_{1}\right)-\int_{d_{2}}^{x^{u}}\left(s-d_{2}\right)\right]-\phi \frac{d_{2}-d_{1}}{r+\lambda+\phi} \\
& =A-\phi \frac{d_{2}-d_{1}}{r+\lambda+\phi} \neq A
\end{aligned}
$$

We have proved by contradiction that case $\mathrm{C}$ is impossible. 
WORKING PAPERS*

Editor: Nils Gottfries

2009:2 Chuan-Zhong Li and Gunnar Isacsson, Valuing urban accessibility and air quality in Sweden: A regional welfare analysis. 24pp.

2009:3 Luca Micheletto, Optimal nonlinear redistributive taxation and public good provision in an economy with Veblen effects. $26 \mathrm{pp}$.

2009:4 Håkan Selin, The Rise in Female Employment and the Role of Tax Incentives. An Empirical Analysis of the Swedish Individual Tax Reform of 1971. 38 pp.

2009:5 Lars M. Johansson and Jan Pettersson, Tied Aid, Trade-Facilitating Aid or Trade-Diverting Aid? 47pp.

2009:6 Håkan Selin, Marginal tax rates and tax-favoured pension savings of the selfemployed Evidence from Sweden. 32pp.

2009:7 Tobias Lindhe and Jan Södersten, Dividend taxation, share repurchases and the equity trap. 27pp.

2009:8 Che-Yuan Liang, Nonparametric Structural Estimation of Labor Supply in the Presence of Censoring. 48pp.

2009:9 Bertil Holmlund, Incentives in Business and Academia. 12pp.

2009:10 Jakob Winstrand, The Effects of a Refinery on Property Values - The Case of Sweden. 27pp.

2009:11 Ranjula Bali Swain and Adel Varghese, The Impact of Skill Development and Human Capital Training on Self Help Groups. 28pp.

2009:12 Mikael Elinder. Correcting Mistakes: Cognitive Dissonance and Political Attitudes in Sweden and the United States. 25 pp.

2009:13 Sören Blomquist, Vidar Christiansen and Luca Micheletto: Public Provision of Private Goods and Nondistortionary Marginal Tax Rates: Some further Results. 41pp.

2009:14 Mattias Nordin, The effect of information on voting behavior. 34pp.

2009:15 Anders Klevmarken, Olle Grünewald and Henrik Allansson, A new consumer price index that incorporates housing. $27 \mathrm{pp}$.

2009:16 Heléne L. Nilsson, How Local are Local Governments? Heterogeneous Effects of Intergovernmental Grants. 41pp.

\footnotetext{
* A list of papers in this series from earlier years will be sent on request by the department.
} 
2009:17 Olof Åslund, Per-Anders Edin, Peter Fredriksson and Hans Grönqvist, Peers, neighborhoods and immigrant student achievement - evidence from a placement policy. $27 \mathrm{pp}$.

2009:18 Yunus Aksoy, Henrique S. Basso and Javier Coto-Martinez, Lending Relationships and Monetary Policy. 42 pp.

2009:19 Johan Söderberg, Non-uniform staggered prices and output persistence. $38 \mathrm{pp}$.

2010:1 Jonathan Gemus, College Achievement and Earnings. 43 pp.

2010:2 Susanne Ek and Bertil Holmlund, Family Job Search, Wage Bargaining, and Optimal Unemployment Insurance. 30 pp.

2010:3 Sören Blomquist and Laurent Simula, Marginal Deadweight Loss when the Income Tax is Nonlinear. $21 \mathrm{pp}$.

2010:4 Niklas Bengtsson, The marginal propensity to earn, consume and save out of unearned income in South Africa. 34 pp.

2010:5 Marcus Eliason and Henry Ohlsson, Timing of death and the repeal of the Swedish inheritance tax. 29 pp.

2010:6 Teodora Borota, Innovation and Imitation in a Model of North-South Trade. $44 \mathrm{pp}$.

2010:7 Cristiana Benedetti Fasil and Teodora Borota, World Trade Patterns and Prices: The Role of Productivity and Quality Heterogeneity. 24 pp.

2010:8 Johanna Rickne, Gender, Wages and Social Security in China’s Industrial Sector. 48 pp.

2010:9 Ulrika Vikman, Does Providing Childcare to Unemployed Affect Unemployment Duration? 43 pp.

2010:10 Sara Pinoli, Rational Expectations and the Puzzling No-Effect of the Minimum Wage. 56 pp.

2010:11 Anna Persson and Ulrika Vikman, Dynamic effects of mandatory activation of welfare participants. $37 \mathrm{pp}$.

See also working papers published by the Office of Labour Market Policy Evaluation http://www.ifau.se/ ISSN 1653-6975 